UNIVERSIDADE DE SÃO PAULO

FACULDADE DE FILOSOFIA, CIÊNCIAS E LETRAS DE RIBEIRÃO PRETO DEPARTAMENTO DE EDUCAÇÃO, INFORMAÇÃO E COMUNICAÇÃO PROGRAMA DE PÓS-GRADUAÇÃO EM EDUCAÇÃO

\title{
A IMPORTÂNCIA DA FAMÍLIA, ESCOLA E PARES NO PROCESSO DE ESCOLHA PELO ENSINO MÉDIO TÉCNICO
}

\author{
Mariana Simões Ferreira Cintra
}


Mariana Simões Ferreira Cintra

\title{
A IMPORTÂNCIA DA FAMÍLIA, ESCOLA E PARES NO PROCESSO DE ESCOLHA PELO ENSINO MÉDIO TÉCNICO
}

\begin{abstract}
Dissertação apresentada à Faculdade de Filosofia, Ciências e Letras de Ribeirão Preto da Universidade de São Paulo, como parte das exigências para obtenção do título de Mestre em Educação.
\end{abstract}

Orientador: Prof. Dr. Geraldo Romanelli

Versão Corrigida

Ribeirão Preto

2014 
Autorizo a reprodução e divulgação total ou parcial deste trabalho, por qualquer meio convencional ou eletrônico, para fins de estudo e pesquisa, desde que citada a fonte.

FICHA CATALOGRÁFICA

Ferreira-Cintra, Mariana Simões

A importância da família, escola e pares no processo de escolha pelo ensino médio técnico. / Mariana Simões Ferreira Cintra; Orientador Geraldo Romanelli. - Ribeirão Preto, 2014.

121 p. : il.

Dissertação (Mestrado) - Universidade de São Paulo, 2014.

1.Família. 2.Processo de escolarização. 3.Ensino técnico. 


\section{FOLHA DE APROVAÇÃO}

Nome: FERREIRA-CINTRA, Mariana Simões

Título: A importância da família, escola e pares no processo de escolha pelo ensino médio técnico.

Dissertação apresentada à Faculdade de Filosofia,

Ciências e Letras de Ribeirão Preto da USP, para obtenção do título de Mestre em Educação.

Área de concentração: Educação.

Aprovado em I

Banca Examinadora

Prof. Dr. Instituição:

Julgamento: Assinatura:

Prof. Dr. Instituição:

Julgamento: Assinatura:

Prof. Dr. Instituição:

Julgamento: Assinatura: 


\section{AGRADECIMENTOS}

Ao Geraldo, pela orientação, confiança e ensinamentos ao longo dessa jornada. Por ter sido um exemplo de professor, um mestre em sua definição mais pura. Alguém sempre disposto a ensinar e acolher, capaz de transformar meus erros mais infantis em possibilidades de crescimento e aprendizado. Obrigada por me permitir aprender com você.

Aos sujeitos dessa pesquisa que abriram um pouco de suas vidas, seus desejos e projetos, permitindo que suas trajetórias dessem vida à pesquisa. Meu eterno agradecimento por terem me possibilitado conhecê-los e ouvi-los.

Aos meus pais, Henrique e Paula que, mais do que genitores, são espelhos. Obrigada por estarem sempre presentes, me ensinando e auxiliando todos os dias da minha vida, minhas escolhas, sem dúvida, são o reflexo de tudo que me ensinaram.

Ao Ricardo, meu marido, amigo e namorado, pelo companheirismo e amor. Pela paciência em aceitar minhas ausências durante a escrita dessa dissertação. Pela presença inabalável e insubstituível no meu dia a dia.

Às minhas irmãs, Marina e Marcela pela amizade e pela ajuda sempre que precisei. Obrigada pela presença e pelo exemplo. Aos meus sogros, Dulce e Geraldo e aos meus cunhados Fred, Leandro, Andressa e Isabela pelo carinho de sempre e por aturarem minhas conversas constantes sobre o mestrado.

Ao Guilherme, meu sobrinho lindo e incrível que pela sua inocência e carinho consegue tornar até o pior dos dias iluminado e feliz. E ao meu mais jovem sobrinho ou sobrinha que já antes de nascer traz toda a alegria e esperança que somente uma criança é capaz.

Aos amigos de todas as horas, especialmente à Vanessa e Isabela, sempre tão presentes apesar de qualquer distância. Obrigada pelo afeto, ajuda, pelas leituras, debates e traduções. Obrigada também à querida Bia que em pouco tempo de mestrado conquistaram seu espaço em meu coração, sem sua ajuda e conhecimento este trabalho não teria chegado à formatação necessária. À Lígia, pelo companheirismo nessa trajetória, por compartilhar ideias, as apreensões e alegrias da pós. Obrigada também à minha prima Laís que através de seus conhecimentos tecnológicos me salvou nos momentos que os arquivos pareciam brigar comigo.

Aos professores, de antes, agora e depois, sem seu conhecimento e seu exemplo eu provavelmente não teria chegado até aqui. Um agradecimento especial ao Prof. Elmir pela paciência em tirar dúvidas e indicar textos que possibilitaram o enriquecimento não só desta pesquisa, mas também de sua pesquisadora.

E também à CAPES, pelo fomento à essa pesquisa. 
Então eu aproveito todas as oportunidades realmente que meus pais podem me dar porque a gente não sabe o dia de amanhã né? E o estudo é uma coisa que a gente vai levar pra vida inteira.

Sara, uma das participantes 


\section{RESUMO}

FERREIRA-CINTRA, M.S. A importância da família, escola e pares no processo de escolha pelo ensino médio técnico. 2014. 121f. Dissertação (Mestrado) - Faculdade de Filosofia, Ciências e Letras, Universidade de São Paulo, Ribeirão Preto, 2014.

Esta pesquisa investiga a forma como as relações familiares, escolares e entre pares influenciam o ingresso de adolescentes no ensino técnico integrado ao ensino médio e como se articulam às aspirações e expectativas de pais e filhos quanto a essa modalidade de escolarização dentro do contexto social no qual estão inseridos. Além disso, este trabalho examina o significado e a importância do trabalho dos adolescentes, seus projetos escolares e profissionais para o futuro e como vínculos com determinadas religiões articulam-se com o processo de escolarização. Para tanto foram entrevistados, a partir de roteiro semi-estruturado, 10 adolescentes, entre 17 e 18 anos, cinco do sexo masculino e cinco do sexo feminino, matriculados na quarta série do curso de automação industrial no Instituto Federal de Educação, Ciência e Tecnologia, Campus de Sertãozinho, único instituto federal na região administrativa do município de Ribeirão Preto. A partir de análise das entrevistas, gravadas e transcritas, nota-se que os pais exercem influência nas escolhas dos filhos, principalmente em seu apoio ao processo de escolarização e na importância que atribuem ao trabalho futuro da prole. Ao lado da família, a escola, professores, funcionários e os pares também exercem influência na trajetória escolar dos adolescentes e em sua escolha pelo Instituto Federal, escola considerada de prestígio e de qualidade e que oferece não apenas educação geral, mas também técnica. As entrevistas foram classificadas em dois eixos temáticos: família e escola, trabalho e expectativas, e os dados foram analisados utilizando-se referenciais teóricos da sociologia da educação para se avaliar como a realidade socioeconômica das famílias, ao lado de outros fatores, influencia o processo de escolha das instituições escolares e como os filhos podem incorporar e reformular as orientações parentais.

Palavras-chave: família, processo de escolarização, ensino técnico. 


\begin{abstract}
FERREIRA-CINTRA, M.S. The importance of family, school and pairs in the selection process of the technical high school. 2014. 121f. Dissertação (Mestrado). Faculdade de Filosofia, Ciências e Letras de Ribeirão Preto, Universidade de São Paulo, Ribeirão Preto-SP, 2014.

This research aims to investigate how familiar, scholar and pair relationships influence the entry of adolescents in integrated technical education to high school and how it is articulated with the aspirations and expectations of parents and children, regarding this type of schooling, within the social context in which they live. In addition, this paper examines the significance and importance of the adolescents' work, their scholar and professionals projects for the future and how links with certain religions are articulated with the educational process. Therefore, were interviewed, using a semi-structured guide, 10 teenagers between 17 and 18 years old, five males and five females, enrolled in fourth grade of industrial automation course at the Federal Institute of Education, Science and Technology, Campus Sertãozinho, the only federal institution in the administrative region of Ribeirão Preto. From the analysis of interviews that were taped and transcribed, is noted that parents have an important influence on the children's choices, especially on the support of the educational process and the importance they assign to their children future work. Aside to the family, the school, teachers, staff and pairs also exert influence on teenagers' school performance and their choice for the Federal Institute, a school considered prestigious and with quality, offering not only general education but also technical. The interviews were classified into two main themes: family and school, work and expectations, and data were analyzed using theoretical frameworks of sociology of education to assess how the economic reality of families, alongside other factors, influences the process of choosing the educational institution and how the children can incorporate and rework parental guidance.
\end{abstract}

Keywords: family, schooling process, technical education. 


\section{LISTA DE QUADROS}

QUADRO 1 - Características socioeconômicas e familiares das participantes do sexo feminino

QUADRO 2 - Características socioeconômicas e familiares dos participantes do sexo masculino.

QUADRO 3 - Escolarização dos pais e das mães dos sujeitos.

QUADRO 4 - Expectativas em relação ao ensino superior e atividade dos alunos após a conclusão do ensino médio 
CAPÍTULO 1: INTRODUÇÃO

CAPÍTULO 2: ENSINO TÉCNICO E FAMÍlIA: ESCOLHAS

$2.1 \mathrm{O}$ ensino técnico: transformações e possibilidades ............................................ 15

2.2 Ensino técnico integrado ao ensino médio ....................................................... 20

2.3 O Instituto Federal de Educação, Ciência e Tecnologia de São Paulo, Campus

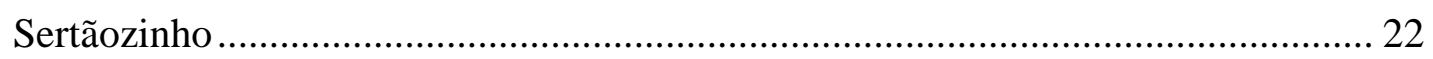

2.4 O curso: técnico integrado ao ensino médio em Automação Industrial .............. 24

2.5 Estratégias de escolha e escolha das estratégias................................................. 26

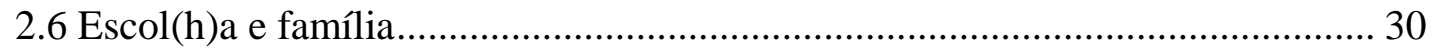

CAPÍTULO 3: OBJETIVOS, METODOLOGIA E TRABALHO DE CAMPO ... 36

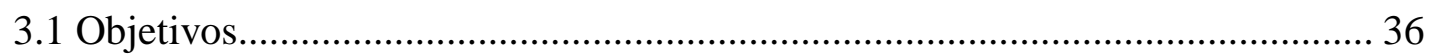

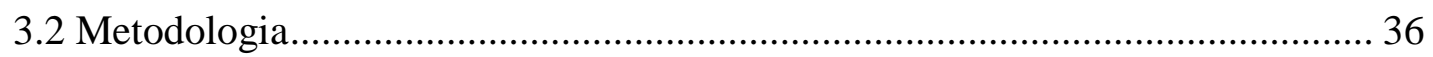

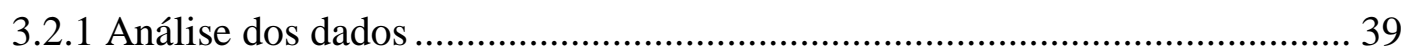

3.2.2 Sujeitos da pesquisa: critérios de inclusão e escolha dos sujeitos ................. 39

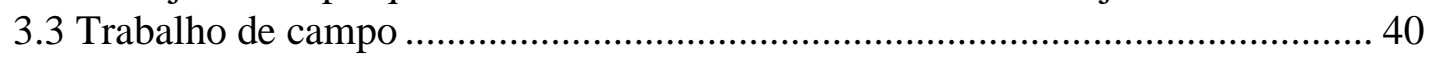

CAPÍTULO 4: PERFIL DOS PARTICIPANTES DA PESQUISA .......................... 42

4.1 Daisy, preta, 17 anos, família nuclear ............................................................. 42

4.2 André, pardo, 18 anos, família nuclear............................................................... 44

4.3 Amanda, branca, 17 anos, família nuclear ................................................... 45

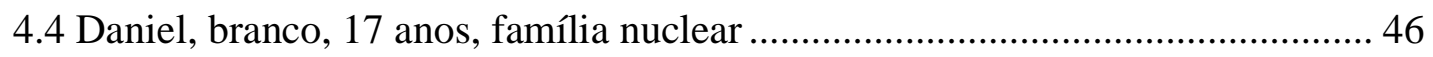

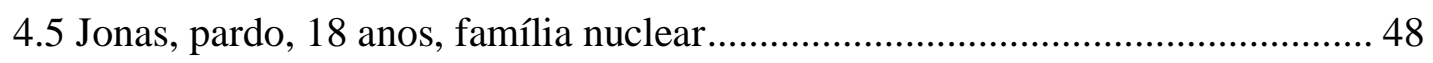

4.6 Sara, preta, 18 anos, família recomposta ............................................................ 49

4.7 Vanda, preta, 18 anos, família nuclear ............................................................ 50

4.8 Cíntia, branca, 18 anos, família matrifocal.................................................... 52

4.9 Cássio, branco, 18 anos, família recomposta ................................................ 53

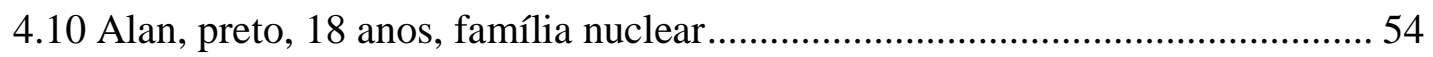

4.11 Os percalços do trabalho de campo ............................................................... 55

CAPÍTULO 5: FAMÍLIA E ESCOLA ........................................................................ 58

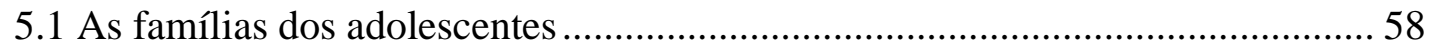

5.2 As relações dos adolescentes com a família e a escola de ensino fundamental . 64

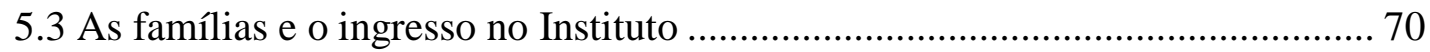

5.4 Os adolescentes e suas relações com a religião e com os pares …….................. 80 
5.5 A apropriação do conhecimento e a sociabilidade no Instituto 82

CAPÍTULO 6: TRABALHO E EXPECTATIVAS FUTURAS ................................ 86

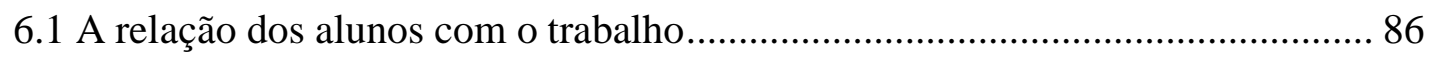

6.2 As perspectivas de trabalho após a conclusão do ensino técnico ....................... 91

6.3 As expectativas de ingresso no ensino superior .............................................. 92

6.4 Os alunos após a conclusão do ensino técnico ................................................. 96

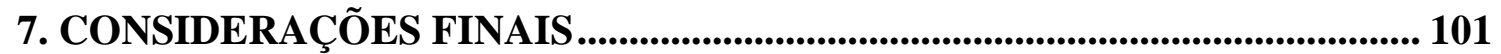

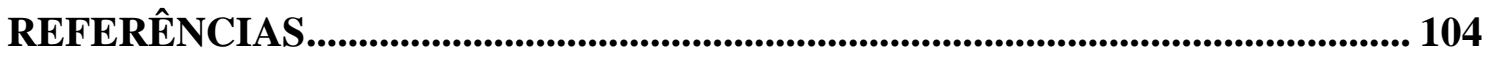

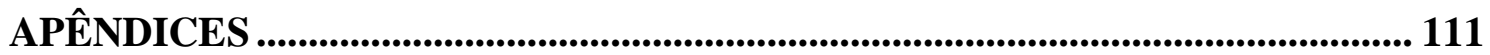

APÊNDICE A - Roteiro de Entrevistas............................................................. 111

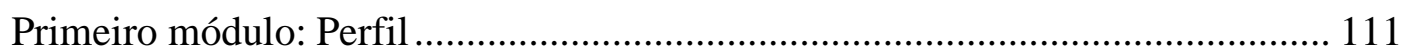

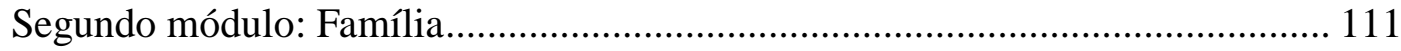

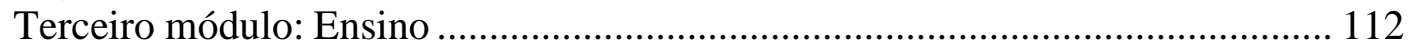

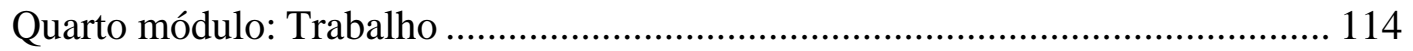

Quinto módulo: Expectativas em relação ao futuro ............................................. 114

APÊNDICE B - Relação candidato/vaga entre 2009 e 2013 nos cursos técnicos integrados ao ensino médio de automação industrial e química............................................. 115

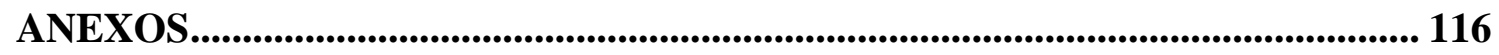

ANEXO A - Número de alunos matriculados de acordo com a renda família per capita

ANEXO B - Infraestrutura do Campus de Sertãozinho ....................................... 117

ANEXO C - Infraestrutura detalhada do IFSP - Campus Sertãozinho. .................. 118

ANEXO D - Estrutura curricular do curso de Automação Industrial .................... 120

ANEXO E - Documento de aprovação enviado pelo Comitê de Ética ................... 121 


\section{CAPÍTULO 1: INTRODUÇÃO}

A trajetória educacional de um indivíduo conecta-se a vários fatores que se articulam e/ou desarticulam no tempo e no espaço em que o indivíduo se encontra inserido e são marcados por reformulações ou mudanças das trajetórias. Tais fatores não estão ligados somente à escola, e nem mesmo somente à família ou à origem social dos pais, o que se tem é uma constante articulação entre eles, podendo transformar ou manter a trajetória pessoal dos sujeitos.

O conceito de trajetória, de acordo com Romanelli (2003), remete às experiências vividas por cada indivíduo ao longo do tempo e da convivência com outras pessoas, com a família e com outros grupos sociais. As trajetórias individuais são construídas por articulações entre o plano individual e o coletivo, de tal modo que os projetos de cada um podem entrar em conflito com aspirações do grupo familiar.

Dada essa composição múltipla das trajetórias individuais é fundamental olhar a escola, mas também analisar outras instituições que afetam a formação dos sujeitos. Conforme Sposito (2003), é importante considerar o sujeito que existe para além do aluno, que se busque compreender como o não-escolar afeta o escolar, para que assim se possa alcançar um entendimento não do aluno ou da escola, mas dos múltiplos sujeitos e trajetórias que ajudam a compor o espaço escolar.

Lahire (1997) e Singly (2000) abordam a necessidade de se considerar a interdependência na identidade dos sujeitos a partir da sua relação com o outro. Por sermos seres sociais, desde o nascimento necessitamos dessa interação com múltiplos outros para a construção da nossa consciência interior. Porém, enquanto Lahire tece uma crítica ao termo indivíduo que poderia levar ao entendimento de que os sujeitos se formam isoladamente, Singly o amplifica, mostrando através do surgimento do indivíduo individualizado, a importância das relações sociais e afetivas na construção das identidades. Desse modo, "inversamente ao que o termo individualismo pode levar a crer, o indivíduo precisa assim, para tornar-se ele mesmo, do olhar das pessoas a que ele atribui importância e sentido" (SINGLY, 2000, p. 14).

Berger e Luckmann (1985) ao analisarem o processo de socialização primária demonstram que "os outros significativos" são os responsáveis por transmitir aos mais jovens, logo que nascem, os valores, normas e comportamentos de determinado grupo social no qual o indivíduo está inserido. A família, portanto, transmite não somente conhecimentos e visões 
de determinada classe/camada social, mas também impregna esse indivíduo com orientações para a vida social provenientes do contexto em que vive. Por esse motivo:

[...] uma criança da classe inferior não somente irá habitar um mundo grandemente diferente do que é próprio da criança de uma classe superior, mas pode chegar a ter um mundo inteiramente diferente daquele da criança de classe inferior que mora na casa ao lado. (BERGER E LUCKMANN, 1985, p. 176).

A família, nesse contexto, configura-se, segundo Durham (1983), Romanelli (2003) e Berger e Luckmann (1985), como uma das principais instituições socializadoras, o que permite dizer que ela é a responsável pelo primeiro contato que os sujeitos têm com o mundo social, suas normas e seus valores. Porém, o processo socializador não é mecânico e a incorporação das orientações familiares não depende apenas da atuação ou imposição parental, mas está associada ao modo como cada filho reage, incorpora ou rejeita essas orientações (MONTANDON, 2005), de tal modo que em uma mesma família os irmãos podem apresentar diferenças de comportamento e desempenho (LAHIRE, 1997).

Família é um termo plural que carrega em si grandes possibilidades de arranjos e é preciso estabelecer limites para a definição do que é família. Nesse sentido, como afirma Durham (1983) pode-se entender família como unidade de reprodução social criada por laços de aliança ou afinidade, de consanguinidade e de descendência. Assim, em sentido genérico, família pode ser compreendida a partir de duas noções: "a de grupo, segmento empiricamente delimitável e socialmente reconhecido; e a de reprodução" (DURHAM, 1983, p. 26), sendo que nesta última acepção engloba tanto a reprodução biológica quanto a social.

Se famílias são:

[...] grupos sociais de convivência e procriação nos quais há relações personalizadas e próximas que são atravessadas por expressões de afeto, que tanto podem assumir características positivas de proteção, solidariedade, amparo, como podem apresentar traços negativos, de competição, conflito, rancor, são também instituição, isto é, situam-se igualmente no plano da cultura. (ROMANELLI, 2013).

Ao mesmo tempo, famílias são instituições e são caracterizadas por normas que definem direitos e obrigações dos membros e limites entre eles e os não-membros. Os tipos de afeto e intimidade referidos à família são ainda governados por esse complexo de normas e uma brecha nas normas - que certamente ocorre - não significa que elas tenham desaparecido (THERBORN, 2006). 
Desse modo, famílias constituem-se como instituição e grupos de convivência social regidos por normas culturais, que não são fixas e perenes, mas que passam por transformações sociais ao longo do tempo e de acordo com o segmento social a que elas pertencem.

Mesmo considerando essa generalidade conceitual de família, no plano da organização empírica as famílias não se configuram de forma unívoca e assumem diferentes modalidades de arranjos em momentos históricos específicos. No presente, a organização doméstica ainda predominante é a família nuclear, formada por pais e filhos. Ao lado desse arranjo há outras modalidades de família, como as ampliadas, composta pela família nuclear acrescida de integrantes da parentela, isto é, parentes do lado paterno e materno, como avós, sobrinhos e primos; e monoparentais, em que apenas um dos pais vive com os filhos e é responsável por sua criação. Esse arranjo assume a forma de famílias matrifocais quando a mãe é a detentora da responsabilidade pela criação dos filhos ou de famílias patrifocais, quando o pai é o responsável pela criação e socialização da prole. Outro arranjo que vem crescendo é de famílias recompostas, quando marido ou esposa, com filhos de uma primeira união, separamse e casam-se novamente (ROMANELLI, 2003).

Além disso, uma mesma família passa por transformações ao longo de sua história que podem alterá-la, como separação do casal, novas uniões, morte ou doença de um dos cônjuges, desemprego e ainda da idade de seus componentes. Todas essas alterações permitem dizer que uma família nunca é a mesma ao longo de sua trajetória. Romanelli (2003) demonstra isso ao ressaltar as diferenças que ocorrem durante a criação dos filhos, nas quais as novas experiências nas trajetórias de pai e mãe, as possíveis flutuações econômicas e sociais, fazem com que os pais que criaram um filho não sejam, nunca, os mesmos que criaram o outro. As trajetórias individuais dos membros, portanto, influenciam e interferem na trajetória familiar.

Não se pode perder de vista que ao lado da família outras instituições como escolas, igrejas, grupos de pares, meios de comunicação e o mundo do trabalho contribuem igualmente para o processo socializador, ainda que em sua forma secundária, quando o indivíduo já foi socializado anteriormente.

Portanto, a trajetória escolar e profissional dos jovens é atravessada por esses grupos sociais, notadamente a família, seguida pela escola e pelos pares. Desse modo pretende-se verificar como se articulam os interesses, aspirações e expectativas desses sujeitos em relação à escolha pelo ensino técnico integrado ao ensino médio e suas possibilidades de inserção no mundo adulto, seja através do prosseguimento dos estudos no ensino superior e ou do ingresso no universo do trabalho formal. 


\section{CAPÍtULO 2: ENSINO TÉCNICO E FAMÍlIA: ESCOLHAS E TRANSFORMAÇÕES}

\subsection{O ensino técnico: transformações e possibilidades}

O desenvolvimento do ensino técnico está ligado à era escravocrata, na qual vários ofícios manuais eram tidos como funções de escravos, e, portanto, eram rejeitados por outros estratos da população. Esse tipo de ensino só era oferecido aos homens livres em momentos de muita necessidade de complementação da mão-de-obra e, ainda assim, destinados apenas aos jovens e crianças, em sua maioria, órfãs, e em precárias condições de vida ${ }^{1}$, como no caso do Colégio das Fábricas, criado em 1809. Este colégio serviu de modelo para todas as escolas que vieram depois (CUNHA, 2000), inclusive para a Escola de Aprendizes Artífices, fundada em 1909, que deu origem ao Instituto Federal de Educação, Ciência e Tecnologia² ${ }^{2}$

Após a Independência do país e da laicização do Estado, o poder público tornou-se o principal interessado na melhoria e no aperfeiçoamento da educação brasileira. Embora a educação formal tenha passado por várias mudanças, que não constituem objeto deste trabalho, com a educação técnica não poderia ser diferente.

De modo sintético, pode-se considerar que a educação profissional no Brasil passou por várias modificações legislativas ao longo de seu desenvolvimento, sendo marcada a partir da década de 1930 pela dicotomia entre escola para ricos e escola para pobres. As primeiras deveriam oferecer formação geral para os alunos enquanto as demais, dedicadas ao ensino profissionalizante, voltavam-se para preparar os alunos para o mundo do trabalho. Tal dicotomia visava preparar e qualificar os alunos dessas escolas para ingresso precoce no mercado de trabalho de modo a acompanhar as novas demandas de mão-de-obra necessárias para o desenvolvimento industrial brasileiro, que começava a se ampliar no início do século XX, conforme Tuppy (2002) ressalta.

Esse autor descreve como a Lei $\mathrm{n}^{\circ}$ 5.692/71, apesar de ter sido formulada aparentemente para acabar com essa dicotomia, promovendo a interação entre os ensinos profissional e propedêutico em todas as instituições de ensino de segundo grau e, portanto,

\footnotetext{
${ }^{1}$ Durante anos o ensino médio técnico esteve destinado à população de baixa renda e ocorria de forma "livre, isto é, não fornecia um diploma reconhecido legalmente" (CUNHA, 1977). Com a criação do Serviço Nacional de Aprendizagem Industrial (SENAI), em 1942, as escolas técnicas se organizaram e começaram a abandonar o estereótipo de escolas para pobres e se voltarem a outras camadas sociais de modo a conquistar mais espaço na organização social brasileira, desenvolvendo processos seletivos para o ingresso de alunos.

2 Atualmente no estado de São Paulo esse Instituto conta com 22 mil alunos distribuídos por 28 campi, que oferecem os cursos de Técnico Integrado, Técnico concomitante ou subsequente, Proeja, Ensino Superior e de Pós-Graduação, além de 23 polos de Educação à distância. (INSTITUTO FEDERAL SÃO PAULO).
} 
tornando acessível as duas modalidades de ensino tanto às classes mais abastadas quanto as menos abastadas, acabou por acentuar as diferenças pré-existentes. Segundo Tuppy (2002, p.112) "o ensino profissionalizante [...] representava um custo $60 \%$ mais alto do que o ensino propedêutico, já carente", e o aumento de gastos nas escolas públicas acabou por aumentar a dicotomia entre as escolas públicas $\mathrm{e}$ as privadas que conseguiram transformar a obrigatoriedade da carga horária de ensino profissionalizante em "habilitações básicas" que mesclavam conhecimentos técnicos e propedêuticos. Essa estruturação das escolas particulares manteve o monopólio de ingresso de seus alunos no ensino superior, mantendo os jovens das camadas mais baixas distantes do ensino superior. Ao mesmo tempo em que as escolas particulares articulavam seus interesses ao disposto pela lei o aumento dos gastos das escolas públicas com a manutenção do ensino profissionalizante e propedêutico, culminou na decadência das escolas públicas especializadas.

A Lei $\mathrm{n}^{\circ}$ 7.044/82 alterou a legislação anterior e retirou do texto da lei a obrigatoriedade das escolas de segundo grau fornecerem educação profissionalizante, conforme parágrafo dois do Art. $4^{\circ}$. Essa alteração apenas liberou ainda mais as escolas particulares, que não precisando oferecer em sua carga horária disciplinas de formação profissional, puderam buscar seu objetivo principal de preparar seus alunos para o ingresso no ensino superior, mantendo a dicotomia entre escola para pobres e escola para ricos (TUPPY, 2002).

Deve-se considerar ainda que já em 1959, o então subdiretor geral da UNESCO (Organização das Nações Unidas para Educação, Ciência e Cultura), afirmou que "em todos os países - mesmo nos mais avançados - o ensino técnico desenvolveu-se no quadro de uma ação empírica, muitas vezes mesmo caótica, e está exposto [...] à dura lei da oferta e da procura" (BREJÓN, 1968, p. 60). Isso, por si só, já demonstra o tamanho da problemática em questão, uma vez que os cursos técnicos não estão sujeitos somente a alterações formais no currículo, mas principalmente às necessidades impostas pelo mercado de trabalho.

A Lei de Diretrizes e Bases de 1996, por sua vez, normatizou a escola básica e os níveis de ensino posteriores, instituindo a composição da primeira em três etapas: educação infantil, ensino fundamental e ensino médio. Apesar de não normatizar o ensino profissionalizante, a LDB, conforme Tuppy (2002, p.116) chama a atenção, deixou uma brecha no oferecimento dessa modalidade de ensino como consta do $\S 4^{\circ}$ do Art. 36 que determina que as instituições de ensino podem oferecer, facultativamente, preparação profissional em seus próprios estabelecimentos, como pode ser notado no trecho da LDB: 
(...) a preparação para o trabalho e, facultativamente, a habilitação profissional, poderão ser desenvolvidas nos próprios estabelecimentos de ensino médio ou em cooperação com instituições especializadas em educação profissional.

O referido parágrafo da LDB, posteriormente revogado pela Lei $n^{\circ} 11.741 / 2008$, abriu espaço para a criação do Decreto $n^{\circ} 2.208 / 97$, que regulamentou o oferecimento da educação profissional em instituições especializadas, nos próprios ambientes de trabalho ou em escolas de ensino regular, conforme previa o parágrafo da LDB anteriormente citado. Esse Decreto foi revogado pelo Decreto 5.154/2004 que será discutido adiante.

Tuppy (2002, p.116), também ressalta que além das constantes alterações legislativas, a formação profissional do ensino médio "sempre carregou um sentido de terminalidade, visto que, [...], tende a impedir o trânsito de estudantes, particularmente da classe trabalhadora, para o ensino superior". Há que se considerar, entretanto, que as transformações do mercado de trabalho ao exigirem trabalhadores mais qualificados podem acabar estimulando os jovens que cursam o ensino técnico integrado, ou concomitante ao ensino médio, a buscarem o ingresso em universidades, conforme aponta Loponte (2011) em estudo sobre o campus do Instituto Federal da cidade de São Paulo e que será abordado adiante.

Uma transformação ocorrida mais recentemente e retratada por Cassiola (2002), Wermelinger, Machado e Amâncio Filho (2007), Oliveira (2009) e Ferretti (2011) é a de que os cursos técnicos não estão mais diretamente relacionados somente ao ensino de ofícios manuais, mas à formação de jovens capacitados para a análise do mundo em que estão inseridos, transformando técnicos em trabalhadores completos, e, portanto, mais competitivos e preparados para o mercado de trabalho, possibilitando, inclusive, maiores chances de crescimento profissional.

Nesse sentido, Nepomuceno e Witter (2010, p. 17) descrevem a relevância de fenômenos como a globalização e o desemprego alteram e complexificam as competências exigidas pelo mercado de trabalho, obrigando os indivíduos em época de escolha profissional a levarem em consideração outros fatores e não somente o que esses autores qualificam como fator "biológico (vocacional)", mas também, e principalmente, questões como: "mercado de trabalho, importância social, remuneração, tipo de trabalho (braçal/intelectual) e as habilidades necessárias para o seu desempenho" (NEPOMUCENO E WITTER, 2010, p. 17).

Mueller, Bianchetti e Jantsch (2008, p.185) ressaltam que as próprias transformações sofridas pelo sistema capitalista com a passagem do modelo taylorista-fordista para o toyotista passaram a exigir que os trabalhadores "estejam sempre dispostos a mudanças [...], sejam flexíveis e estejam sempre abertos às transformações [...] organizacionais que as empresas 
precisam implementar”, o que forçou alterações na estrutura curricular dos cursos técnicos pela necessidade de adicionarem conteúdos voltados para a formação pessoal do jovem, atribuindo-lhe uma posição mais completa tanto no mercado de trabalho quanto na sociedade.

Esse movimento já estava aparente na determinação da Resolução CNE/CEB nº4/99, de 08/12/1999, que enfatiza o modelo de competências como o paradigma a ser adotado pelas escolas técnicas, no qual:

[...] competência designa saber ser, mais do que saber fazer e implica dizer que o trabalhador competente é aquele que sabe utilizar todos os seus conhecimentos - obtidos através de vários meios e recursos - nas mais diversas situações encontradas em seu posto de trabalho (HIRATA, 1993, p.100 apud FERRETTI, 1997).

Nessa interpretação, criticada por Ferretti (1997), o modelo de competências, portanto, seria essencial na construção de um trabalhador completo.

A história do desenvolvimento da educação técnica no Brasil, além de passar por frequentes alterações curriculares, provoca outro fato estudado por Nogueira (1998), que, apesar de não citar diretamente em seu trabalho o ensino técnico, pode ser aqui apropriada. Trata-se da heterogeneidade entre os conteúdos oferecidos pelos cursos e escolas e que podem ser encontradas nas escolas de ensino médio técnico. Esse fato provoca maior preocupação e maior participação familiar no ato da escolha da instituição, uma vez que o grande número de opções e transformações escolares e familiares ao longo de anos acaba complexificando o processo de escolha.

Aliado a essa realidade, no caso dos cursos técnicos, há ainda o aspecto do mercado de trabalho, que também deveria ser um critério de escolha, embora muitos adolescentes não tenham informações suficientes sobre tais cursos. Moura e Silveira (2002) ressaltam que é importante apreender como as regras, os pensamentos e sentimentos sobre a escolha profissional e o peso dos contextos sociais nos quais os jovens estão inseridos afetam seus processos de escolha, bem como a forma como esses adolescentes tem acesso à informação sobre os cursos técnicos.

$\mathrm{Na}$ tentativa de resolver as disparidades curriculares e facilitar o processo de escolha, foi aprovado em 2008 um Catálogo Nacional de Cursos Técnicos (MINISTÉRIO DA EDUCAÇÃO, 2008) que prevê a formação de eixos temáticos capazes de auxiliar os estudantes no momento da escolha e padronizar o ensino no país. Esse Catálogo ainda prevê alterações de caráter regional nesses eixos para adequá-los às características próprias da economia e do tipo de setor industrial dominante em cada região, de modo a realmente 
conseguir oferecer aos estudantes uma educação profissional que vá ao encontro de sua realidade. Portanto, esse Catálogo, ao mesmo tempo em que permite a flexibilização dos cursos oferecidos, consegue explicitar de forma mais clara os objetivos de cada um deles, tornando-os mais acessíveis e próximos da realidade vivenciada pelo público ao qual se destina.

Da mesma forma, o Decreto $n^{\circ} 5.154 / 2004$ dispõe no artigo $4^{\circ}$, a formulação do ensino médio técnico de três formas, sendo que todas são oferecidas pelo IFSP (Instituto Federal de Educação, Ciência e Tecnologia de São Paulo):

$\S 1^{\circ} \mathrm{A}$ articulação entre a educação profissional técnica de nível médio e o ensino médio dar-se-á de forma:

I - integrada, oferecida somente a quem já tenha concluído o ensino fundamental, sendo o curso planejado de modo a conduzir o aluno à habilitação profissional técnica de nível médio, na mesma instituição de ensino, contando com matrícula única para cada aluno;

II - concomitante, oferecida somente a quem já tenha concluído o ensino fundamental ou esteja cursando o ensino médio, [...] pressupõe a existência de matrículas distintas para cada curso.

III - subseqüente, oferecida somente a quem já tenha concluído o ensino médio (BRASIL, 2004).

Ferretti (2011) ressalta que a criação do ensino técnico integrado provocou um impasse, uma vez que a incorporação de mais horas-aula das disciplinas de caráter geral poderia acabar afastando os cursos técnicos de seu objetivo histórico-econômico fundamental, que era o de formar mão-de-obra qualificada para o mercado de trabalho. A solução encontrada então, e que inclusive aparece determinada pelo Parecer CNE/CEB N 39/2004, foi aumentar a carga horária das disciplinas técnicas, ampliando o tempo de estudo em um ano, ou seja, enquanto o ensino médio regular é desenvolvido em três anos, o ensino técnico integrado ao ensino médio ocorre em quatro anos e é esse o modelo seguido pelos Institutos Federais. Porém, é imprescindível, que não ocorra nos currículos dos cursos integrados, uma divisão interna que separe, por exemplo, em anos de duração, a primeira metade do curso para as disciplinas técnicas e a outra metade para as tradicionais do ensino médio.

[...] é importante deixar claro que, na adoção da forma integrada, o estabelecimento de ensino não estará ofertando dois cursos [...] trata-se de um único curso, com projeto pedagógico único, com proposta curricular única e com matrícula única (MINISTÉRIO DA EDUCAÇÃO, 2005, p.145). 


\subsection{Ensino técnico integrado ao ensino médio}

Existem no Brasil várias instituições responsáveis pelo ensino técnico de nível médio, podendo ser tanto públicas quanto privadas. Dentre as mais importantes, destacaremos o SENAI (Serviço Nacional de Aprendizagem Industrial), subsidiado pela indústria e o CEETEPS (Centro Estadual de Educação Tecnológica Paula Souza), vinculado à UNESP (Universidade Estadual Paulista Júlio de Mesquita Filho) e o IFSP.

O SENAI faz parte do Sistema "S" e do Sistema Indústria e atendendo determinados interesses das indústrias oferece vários tipos de cursos. Além dos cursos técnicos, existem também os de formação continuada para jovens e adultos já inseridos no mercado de trabalho, e o de formação continuada para empresas, organizados segundo pedido das empresas para seus funcionários. Cabe esclarecer que o SESI (Serviço Social da Indústria) não oferece o ensino técnico e quando o faz é na modalidade concomitante e em parceria com o SENAI.

Por abranger vários estados brasileiros o SENAI possui Departamentos Regionais com autonomia para definir as formas de ingresso. No caso de Ribeirão Preto, o SENAI possui uma parceria com o SESI (Serviço Social da Indústria) e o aluno pode optar por cursar o ensino médio e o ensino técnico concomitantemente a partir do segundo ano.

Já o CEETEPS (Centro Estadual de Educação Tecnológica Paula Souza) é dividido em ETECS (Escolas Técnicas) e FATECS (Faculdades de Tecnologia), sendo que as responsáveis pelo ensino técnico integrado ao ensino médio são as ETECS, que atualmente oferecem sete cursos desse tipo na cidade de São Paulo.

Por sua vez, os Institutos Federais contam com escolas espalhadas por todo o Brasil, oferecendo cursos técnicos, licenciaturas, graduações na área de tecnologia e pós-graduação. No caso do IFSP são, atualmente, 22 mil alunos distribuídos por 28 campi, que oferecem os cursos técnico integrado, técnico concomitante ou subsequente, PROEJA, ensino a distância, ensino superior e de pós-graduação. O Instituto Federal de São Paulo surgiu a partir da Escola de Aprendizes Artífices, criada em 1909, e recebeu também os nomes de Escola Técnica Federal de São Paulo e Centro Federal de Educação Tecnológica de São Paulo, tornando-se Instituto pela Lei ${ }^{\circ} 11.892 / 2008$, que institui no Art. $2^{\circ}$ :

Os Institutos Federais são instituições de educação superior, básica e profissional, pluricurriculares e multicampi, especializados na oferta de educação profissional e tecnológica nas diferentes modalidades de ensino, com base na conjugação de conhecimentos técnicos e tecnológicos com as suas práticas pedagógicas, nos termos desta Lei. (BRASIL, 2008). 
Na Região Administrativa de Ribeirão Preto o único ${ }^{3}$ município que possui um Instituto Federal é Sertãozinho, cidade de 110.074 habitantes, e que hoje, conforme informação do website Sertãozinho.com é "um dos mais importantes centros agro-industriais do Estado de São Paulo", devido sobretudo ao desenvolvimento da cana-de-açúcar, apresentando um PIB per capita superior ao do município de Ribeirão Preto ${ }^{4}$.

No IFSP (Instituto Federal de Educação, Ciência e Tecnologia de São Paulo), campus Sertãozinho, existem os cursos superiores presenciais de licenciatura em Química, Tecnologia de Automação Industrial, Tecnologia em Fabricação Mecânica, Tecnologia em Gestão de Recursos Humanos e os Técnicos Integrados em Administração e Mecânica na modalidade EJA (Educação de Jovens Adultos) e os técnicos integrados em Automação e Química. Estes dois últimos cursos são oferecidos a alunos que já completaram o ensino fundamental e neles ingressaram através de vestibular anual que avalia seus conhecimentos gerais em História, Geografia, Português, Matemática, Biologia, Química e Física, e possuem duração de quatro anos, conferindo, ao final, o diploma do ensino médio e do ensino técnico, portanto, capacitando o aluno tanto a ingressar no mercado de trabalho quanto a continuar os estudos em universidades.

Ao se considerar a necessidade de formação voltada para a busca de emprego, a escola de ensino médio técnico pode ser, paradoxalmente, uma alternativa para manter os alunos durante mais tempo no processo educacional, instigando-os a dar continuidade aos estudos pelo ingresso em universidades. Esse movimento de permanência no sistema educacional foi notado por Loponte (2011), em sua análise das expectativas dos alunos no IFSP de São Paulo.

A autora trabalha com a hipótese de que jovens escolhem o ensino técnico não pensando em uma relação direta entre estudo e ingresso no mercado de trabalho, mas também "com o objetivo de ter uma formação técnica reconhecida e gratuita e também para adquirir um bom preparo para a universidade" (LOPONTE, 2011, p. 2), uma vez que essas escolas são reconhecidas por sua qualidade e prestígio. Nessa esteira, Loponte (2011) se aproxima da análise de Cunha (1977, p. 103) para quem "o ensino técnico industrial, além da função manifesta e óbvia de formar técnicos industriais, desempenhou a função de preparar candidatos para cursos superiores".

O contexto em que os alunos da pesquisa de Loponte (2011) estão inseridos, uma grande capital, pode influenciar a percepção das necessidades impostas pelo mercado de

\footnotetext{
${ }^{3}$ Em novembro de 2013 foi aprovada a instalação de uma unidade do Instituto Federal no município de Ribeirão Preto.

${ }^{4}$ Segundo o Censo do IBGE de 2010, Sertãozinho apresenta um PIB per capita de R\$37.438,57, enquanto o de Ribeirão Preto é de R\$26.083,97 (INSTITUTO BRASILEIRO DE GEOGRAFIA E ESTATÍSTICA, 2010c).
} 
trabalho, como a constante atualização e especialização dos trabalhadores. Por isso, a autora esclarece que $44,4 \%$ dos entrevistados demonstravam tanto o interesse em ingressar no mercado de trabalho quanto o de cursar uma universidade, sem, porém, deixarem claro os momentos em que essas atividades seriam realizadas, se concomitante ou separadamente.

\subsection{O Instituto Federal de Educação, Ciência e Tecnologia de São Paulo, Campus Sertãozinho}

Segundo o Instituto Brasileiro de Geografia e Estatística (2010a) o município de Sertãozinho, localizado no interior do estado de São Paulo, extrai a maior parte de seu produto interno bruto do setor industrial. Sua característica de polo industrial torna-o, portanto, lócus privilegiado para a implementação de cursos técnicos voltados para o setor industrial. Segundo informações divulgadas pela Prefeitura Municipal através de seu website sertaozinho.gov, as indústrias são principalmente de base, transformação, usinagem, fundição e outras que produzem bens de consumo e/ou de produção para diversos setores, inclusive o de automação industrial. Essas características contribuem para explicar a existência do curso de ensino técnico nessa cidade uma vez que sua implementação depende da necessidade de força de trabalho da região em que cada Instituto está inserido.

Essas informações sobre a cidade são apresentadas no Plano de Curso (INSTITUTO FEDERAL SÃO PAULO, 2007, p. 7) o qual consta:

Em todo o período de funcionamento, a Direção da Escola vem mantendo contatos com representantes do empresariado local, procurando, assim, diagnosticar as necessidades de formação profissional mais emergentes e propor formas de atendimento.

O Instituto Federal de Educação, Ciência e Tecnologia de São Paulo, Campus Sertãozinho - que será denominado a seguir apenas como Instituto para facilitar a exposição surgiu nessa cidade em 1996, através de convênio entre a Prefeitura, a Secretaria de Educação Média e Tecnológica e o Centro Federal de Educação Tecnológica de São Paulo, conforme consta no plano de curso (INSTITUTO FEDERAL SÃO PAULO, 2007). O Instituto passou a ocupar o atual prédio em 2007 e já foi aprovada licitação para início da expansão das instalações na mesma área em que está localizado conforme publicado no Diário Oficial da União em 23 de agosto de 2013.

O Instituto abriga os cursos técnicos integrados em automação industrial e química, o curso técnico integrado em eletrônica, em parceria com a Secretaria Estadual de Educação, os 
cursos técnicos em administração e mecânica na modalidade PROEJA, e os cursos superiores em química, fabricação mecânica, tecnologia em gestão de recursos humanos e engenharia mecânica, totalizando 903 alunos com matrículas efetivadas no primeiro semestre de 2012, conforme dados do website Instituto Federal São Paulo. Esses alunos são, em sua maioria, provenientes de famílias das camadas populares, com renda familiar per capita entre 0,5 e 1,5 salários mínimos (ANEXO A).

Como auxílio para os alunos de famílias de baixa renda, tanto dos cursos superiores, quanto dos técnicos integrados, a instituição conta com a disponibilização de bolsas PAE (Programa de Assistência Estudantil), para as quais os alunos devem se inscrever e participar de processo seletivo. Os critérios para concessão da bolsa incluem análise da renda familiar e sua classificação em ordem crescente de renda per capita - que vai de meio salário mínimo até um salário mínimo e meio per capita -; profissão e nível de escolaridade do mantenedor, número de membros da família, local de moradia, despesas da família com moradia, comprovação de frequência às aulas no semestre anterior à concessão da bolsa.

A bolsa para os alunos do ensino técnico integrado é de um ano podendo ser renovada, a partir dos critérios acima citados. As bolsas são de duas modalidades; uma de caráter específico subdividida em auxílio-alimentação de $\mathrm{R} \$ 150,00$ - valor máximo -; auxílio moradia de $\mathrm{R} \$ 400,00$; auxílio-transporte de $\mathrm{R} \$ 200,00$. A bolsa pode ser em espécie ou em caráter didático pedagógico que, ao invés de fornecer o auxílio em valor monetário, o faz através de materiais didáticos que porventura não existam disponíveis na biblioteca. A outra modalidade pode ser em caráter geral e atender a projetos elaborados pela comunidade discente ou docente segundo o website do Instituto Federal de Educação, Ciência e Tecnologia.

Ainda conforme dados colhidos no website do Instituto, o corpo docente é formado em sua grande maioria por professores com pós-graduação, sendo que $56 \%$ dos docentes tem o título de mestre, e $28 \%$ são doutores. O campus conta desde 2008 com a publicação da Revista Iluminart ${ }^{5}$ que está em seu décimo número e cujo objetivo é publicar os trabalhos de docentes e discentes do Instituto e de outras instituições de Ensino Superior ou Tecnológico do Brasil. A escola conta com salas de aula, laboratório de informática, laboratórios específicos para aulas práticas, biblioteca, pátio, cantina, anfiteatro e prédio administrativo. Informações detalhadas sobre a área ocupada por algumas dessas instalações podem ser vistas no ANEXO B e das demais instalações no ANEXO C.

\footnotetext{
${ }^{5}$ ISSN: $1984-8625$.
} 
$\mathrm{Na}$ área da cantina e do pátio foram adicionados no segundo semestre de 2013 mesas de pebolim e ping-pong para recreação dos estudantes e que são largamente utilizadas nos horários de intervalo, antes, durante e após as aulas. Além das mesas, a região do pátio conta com bancos e duas mesas grandes usadas para alimentação, estudos e convivência dos alunos e professores. A biblioteca possui livros didáticos tanto de conteúdos gerais quanto técnicos, de literatura, além de apostilas de cursinho pré-vestibular em prateleira específica para assuntos recorrentes de vestibular. Possui também mapas, atlas e periódicos científicos principalmente ligados às áreas técnicas, mas apesar de contar com um acervo relativamente grande os alunos relataram usarem pouco ou quase nunca esse espaço, o que representa uma questão que merece investigação, mas que não cabe no âmbito deste trabalho.

Por contar com cursos superiores e obrigatoriedade de elaboração de Trabalho de Conclusão de Curso também pelos alunos dos cursos técnicos integrados, os corredores da escola são repletos de pôsteres de apresentação científica dos alunos. O Instituto impõe aos discentes da modalidade integrada a realização de estágio na área de formação como condição para a conclusão do curso. As vagas de estágios nas empresas da região são amplamente divulgadas nos quadros de avisos no pátio da escola.

Ainda segundo o plano de curso técnico em automação industrial (INSTITUTO FEDERAL SÃO PAULO, 2007, p. 12), consta que o IFSP de Sertãozinho é a única possibilidade de "qualificação profissional de nível médio, pública e gratuita, na região, voltada para o atendimento mais específico ao polo industrial local”, sendo que o Instituto atende alunos de outras cidades da região, como Ribeirão Preto e Barrinha.

\subsection{O curso: técnico integrado ao ensino médio em Automação Industrial}

O Instituto tem como objetivos específicos a:

[...] formação de técnicos em nível médio; atualização e especialização de profissionais que atuem nas ocupações de nível técnico e formação de mãode-obra qualificada para atuação nos diversos segmentos que possibilitem empregabilidade mais imediata e geração de renda. (INSTITUTO FEDERAL SÃO PAULO, 2007, p. 21).

Os profissionais formados podem trabalhar em três frentes principais: Processos (instrumentação), Manufatura (automação) e Sistemas, incorporando atividades de vários setores industriais, como indústrias químicas, de açúcar e álcool, usinagem, venda e 
distribuição de sistemas etc. todas com campo fértil de trabalho em Sertãozinho e região. O curso de automação industrial é assim definido pelo próprio Instituto:

Automação industrial é a aplicação de técnicas, softwares e/ou equipamentos em uma determinada máquina ou processo industrial, com o objetivo de aumentar a sua eficiência, maximizar a produção com o menor consumo de energia e/ou matérias primas, menor emissão de resíduos, melhores condições de segurança, seja material, humana ou das informações referentes a esse processo, ou ainda, de reduzir o esforço ou a interferência humana sobre esse processo ou máquina (INSTITUTO FEDERAL SÃO PAULO).

De acordo com essa definição o curso de automação industrial está diretamente ligado às necessidades crescentes do mercado de trabalho em produzir mais e melhor de forma cada vez mais competente e rápida. Sendo assim, a escolha por implementar essa modalidade de curso no município de Sertãozinho vai ao encontro, segundo o Plano de Curso Técnico em Automação Industrial de 2007, com a característica da cidade ser um pólo industrial em desenvolvimento. É importante ressaltar, inclusive, que esse curso é oferecido pelo Instituto Federal no estado de São Paulo somente no referido município e na cidade de Salto/SP.

Os cursos técnicos integrados ao ensino médio de Sertãozinho foram criados em 2008 e segundo esclareceu um membro da administração da unidade, "são o sustentáculo da escola". O ingresso é através de processo seletivo com prova igual para todos os campi do IFSP, montado pela Vunesp, com 50 questões objetivas sobre as áreas de ciências, matemática, geografia, história e português. São oferecidas 40 vagas para o curso de automação industrial, porém conforme demonstra a pesquisa existe um alto índice de evasão, uma vez que no ano de ingresso dos alunos da presente pesquisa todas as vagas foram preenchidas, porém, na lista de matriculados no último ano, em 2013, constam somente 26 estudantes, sendo 17 alunos e 9 alunas. Novas pesquisas poderiam ser feitas na tentativa de descobrir se essa evasão ocorre também no curso técnico integrado em química, e investigar as causas atrás desse alto índice de evasão. De qualquer modo, o processo seletivo rigoroso, e não somente pelo formato das provas, como também pelo número de vagas oferecidas, indicam que os candidatos devem ter boa formação no ensino fundamental para concorrer ao ingresso nos cursos do Instituto.

A estrutura curricular do curso mescla disciplinas de formação geral com disciplinas técnicas. Ainda segundo o Plano de curso, as empresas e indústrias da região expressam a necessidade de trabalhadores completos, que tenham conhecimentos técnicos e qualificação profissional específica, mas que também possuam uma formação mais generalista, com habilidades para trabalho em equipe, comprometimento, "boa postura" e "vontade de 
aprender". É nesse contexto que se mesclam ao longo dos quatro anos de curso disciplinas como filosofia, história, segurança e medicina do trabalho, controladores programáveis, gestão organizacional de produção e de pessoas, processos industriais. O quadro completo da grade curricular do curso pode ser visto no ANEXO D.

Apesar de o currículo contemplar áreas de formação geral, os alunos reclamaram da ausência de algumas disciplinas, inclusive História, no último ano de curso, o que pode indicar a importância de conhecimento dessas disciplinas para realização do exame vestibular, e que não estaria sendo oferecida. Trata-se aqui de uma hipótese e uma análise mais aprofundada do currículo precisaria ser melhor explorada em outros estudos.

\subsection{Estratégias de escolha e escolha das estratégias}

O ensino técnico integrado ao ensino médio possibilita ao estudante optar por continuar os estudos no ensino superior ou ingressar no mercado de trabalho, ou ainda realizar as duas atividades concomitantemente. Dado este leque de opções o estudo do processo de escolha pelo ensino médio técnico busca perpassar a influência social da família, dos pares e da escola neste momento, uma vez que dentro deste universo se encontram a realidade escolar e as orientações e aspirações familiares.

Nogueira (1998) e Viana (2005) analisaram como as famílias utilizam estratégias para a escolha das escolas dos filhos. Para Nogueira a realidade socioeconômica das famílias influencia o processo de escolha das instituições escolares. Para demonstrar que o processo de escolha das escolas passa pela utilização de diversas representações e estratégias relacionadas à autopercepção dos envolvidos e à posição que ocupam na sociedade e no mercado de trabalho, a autora analisa quatro pesquisas sobre o tema, duas inglesas ${ }^{6}$ e outras três francesas ${ }^{7}$.

Nas famílias em que os pais têm escolaridade elevada e ocupam melhores postos no mercado de trabalho, eles utilizam estratégias mais bem definidas, preocupando-se em escolher as melhores escolas e considerando a adequação da escola em relação às características específicas de cada filho. No outro extremo, nas famílias cujos responsáveis pertencem ao grupo de profissionais com menor nível de instrução, os critérios usados são

\footnotetext{
${ }^{6}$ BALL, S.; GERWITZ, S.; BOWE, R. School choice, social class and distinction: the realization of social advantage in education. Londres: Centre for Education Studies. King's College, 1994; BALL, S.; GERWITZ, S.; BOWE, R. Markets, choice and equity in education. Buckingham: Open University Press, 1995.

${ }^{7}$ BALLION, R. La bonne école. Paris: Hatier, 1991; HÉRAN, F. École publique, école privée: qui peut choisir? Économie et Statistique, n. 293, p. 5-39, 1996 e LANGOUET, G.; LEGER, A. Public ou privé? - trajectoires et réussites scolaires, Paris: Publidix, 1991.
} 
essencialmente práticos, como distância da escola até a residência, facilidade de locomoção etc. Existiria, portanto, segundo Nogueira (1998), uma relação entre a história de vida dos pais e as decisões sobre o futuro dos filhos.

Já Viana (2005) analisando famílias de camadas populares separa-as em três grupos. Os ambiciosos desde cedo buscam o ensino superior, escolhendo boas escolas para os filhos e preferindo as instituições particulares; para os laboriosos, a possibilidade do ensino superior surge tardiamente e os sortudos, que por desconhecerem o sistema escolar delegam a orientação dos filhos a terceiros, considerados mais competentes.

O processo de escolha, portanto, não se encontra alheio à realidade social das famílias aos quais os filhos pertencem e nem também às possibilidades de transformação que podem ocorrer nesse meio. Resende, Nogueira e Nogueira (2011) demonstram que cada família efetiva esse processo através de um quadro de referências que perpassa tanto as questões econômicas, quanto as aspirações, expectativas, o nível de escolaridade e capital cultural dos pais.

Nessas circunstâncias, Romanelli (2009) afirma que não se pode falar em uma relação intrínseca entre as condições socioeconômicas das famílias e o desempenho escolar dos filhos, uma vez que o elemento definidor é a forma como estão interligados fatores variados que envolvem tanto a organização familiar quanto a escolar. Enquanto a família estabelece vínculos afetivos e consegue tratar cada um de seus membros como um sujeito específico, com habilidades, interesses e necessidades específicas a escola cria laços formais, em que, teoricamente, esses estudantes são tratados a partir de um conjunto de regras e normas prédeterminadas que dificultam - quando não impedem - que esses sujeitos sejam vistos e percebidos de forma mais individualizada.

Conforme Nogueira e Nogueira (2002, p.90 e 92), Charlot (2000) e Lahire (1999) a análise macrossocial bourdieusiana apesar de fornecer conceitos fundamentais para os estudos de educação não pode ser utilizada de forma direta em análises microssociais, em que se busca um contato mais próximo com os "sentidos que os indivíduos atribuem a sua escolarização", uma vez que "a experiência de vida de um sujeito particular dificilmente pode ser deduzido de seu pertencimento a uma coletividade ou do fato de estar inserido numa posição específica da estrutura social". Dito de outro modo, as vivências e formas de incorporação do habitus se dão de forma diferente entre os indivíduos, mesmo entre aqueles que fazem parte de um mesmo conjunto social ou até mesmo familiar.

Na escola há um determinado tipo de relação com os alunos que se pretende geral, quando na verdade, acaba apenas por reforçar as diferenças existentes entre os diversos 
sujeitos que a integram. Nessa esteira, a análise do desempenho escolar necessita de análise mais ampla e é importante incluir a discussão de como família e escola estão estruturadas e de como os sujeitos se apropriam, ou não, das informações que recebem de ambas as instituições, uma vez que cada indivíduo as incorpora de forma distinta.

Na mesma linha, Oliveira e Melo-Silva (2010) argumentam que no caso dos cursos de graduação, o capital cultural e as condições financeiras parentais interferem no desempenho escolar dos filhos, uma vez que nessas relações estão em jogo também as facilidades e/ou dificuldades com que se dá a apropriação de novos conhecimentos através de um novo capital cultural oferecido pela escola e pelos pares.

Bourdieu foi o primeiro autor a desenvolver uma teoria que retirava da escola um caráter neutro e democrático, mostrando que ao invés do que se pensava até a década de 1960, não existia de fato uma igualdade de oportunidades capaz de transformar, através dos dons pessoais de cada indivíduo, sua realidade social. Para Bourdieu era imprescindível que se relacionasse a origem social dos atores a suas oportunidades dentro da escola, uma vez que cada indivíduo possui uma bagagem própria herdada socialmente.

É a partir desse entendimento que Bourdieu descreve quatro tipos principais de capital, o econômico "tomado em termos dos bens e serviços a que ele dá acesso, o capital social, definido como o conjunto de relacionamentos sociais influentes mantidos pela família" (apud NOGUEIRA e NOGUEIRA, 2002, p. 21), o simbólico, determinado pela imagem que os outros têm do sujeito e o capital cultural, que pode ser separado em três tipos, o institucional, apreendido pelos títulos escolares, o objetivado dado pela posse de objetos de alto valor cultural, e o incorporado, referente à "cultura geral", ou seja, ao ensino dos gostos cotidianos como a alimentação, o vestuário, postura, habilidades linguísticas e as artes, passados dos familiares aos indivíduos.

Segundo Bourdieu, o capital pode chegar a todas as pessoas de um grupo da mesma forma, porém, sua internalização o modifica de um indivíduo para outro, ou seja, o habitus, as estruturas subjetivas presentes na realidade de cada um, desde o momento de seu nascimento, vão modificar a forma como cada um se relaciona com as informações a que tem acesso, em outras palavras, cada sujeito interioriza o habitus de acordo com sua própria "história feita corpo" e por sua vez, a exterioriza de um modo diferente.

O habitus seria um “[...] sistema de disposições duráveis e transponíveis que exprime sob a forma de preferências sistemáticas, as necessidades objetivas das quais ele é produto (BOURDIEU, 1983a, p. 82). O habitus tenderia a regular as ações do sujeito, demarcando sua origem e posição social e seria estrutura estruturante que, assimilado pelo indivíduo, torna-se 
parte de sua própria subjetividade ou "natureza". Porém, Bourdieu refere-se, conforme já dito, à disposições e não imposições, desse modo, cada sujeito e cada família pode refletir sua origem e sua classe e adaptá-lo de forma diversa.

Esse entendimento aproxima-se ao exposto por Lahire (1997) que torna clara a não mecanicidade dessa interiorização; a disponibilidade de capitais em determinada situação social ou familiar não determina sua apropriação por todos os membros e nem essa apropriação se dará de maneira igual.

Assim, as relações que cada sujeito mantém com os elementos constituintes de seu habitus e os significados que lhe atribui devem ser analisados de modo que as estruturas sociais não subjuguem o indivíduo na análise. A partir disso, ao mesmo tempo em que não se deve estabelecer uma relação direta entre estrutura e indivíduo, não se pode dizer que ela inexista, ainda que de forma muitas vezes sutil.

O projeto de vida escolar dos sujeitos pode, por exemplo, estar ligado à sua origem familiar, ainda que não necessariamente ao grupo social ou econômico. Um pai com baixa escolaridade, trabalhador manual, poderia incutir nos filhos a importância do trabalho, em suas dimensões econômica se moral, bem como da escola de modo que os filhos exerçam atividade diferente da sua própria, conforme mostra Portes (2000).

Portanto, Bourdieu defende que a dificuldade de aprendizagem dos alunos da população com escassos recursos financeiros não está ligada a uma inferioridade de dons em relação às classes mais abastadas. O que o autor defende é que a escola utiliza códigos próprios do capital cultural de classes mais altas e por isso não consegue atingir e tornar-se inteligível para os membros de outras classes com a mesma facilidade e agilidade, podendo refletir no desempenho escolar dos alunos de classes sociais com menor capital cultural.

A partir de Bourdieu, Viana (2005, p. 114) conclui que “o fracasso escolar (...) não está necessariamente associado à 'omissão dos pais' mas a uma significativa distância com relação às formas escolares de aprendizagem (...)". Sendo assim, conforme Nogueira e Nogueira $(2002$, p.34) as escolas que forem capazes de "promover uma aproximação mais respeitosa entre a cultura escolar e a cultura de origem dos alunos (...) pode(m), no mínimo, adiar o processo de eliminação ou auto-eliminação (desistência dos alunos)”.

O capital cultural, conforme o apreendemos em Bourdieu (1983), seria, então, um fator importante nos projetos de escolarização, sendo que cada família age de forma mais ou menos intensa de acordo com sua própria necessidade de "êxito social" através do "êxito escolar" de seus filhos. 
Ao analisar a escola francesa Bourdieu (1983, p. 116) coloca que a partir do momento em que os filhos das classes populares conquistam o acesso ao ensino secundário os títulos conquistados via escola perdem o efeito que possuíam. Ou seja, antes da "democratização" do acesso escolar o diploma era visto como um elevador ascendente do status social de seus detentores, mas "devido ao fato de que os títulos sempre valem o que valem seus detentores, um título que se torna mais frequente torna-se por isso mesmo desvalorizado, mas perde ainda mais seu valor porque se torna acessível a pessoas sem 'valor social'" (aspas do autor).

Sendo assim, a escolha pelo ensino técnico pode tornar-se, para as camadas populares, uma via mais acessível de mobilidade social, uma vez que possuir um diploma de técnico aos 18 anos pode ser um diferencial perante aquela maioria que possui somente o certificado de conclusão do ensino médio, além também de possibilitar a esses adolescentes o acesso a uma educação gratuita e de melhor qualidade.

\section{6 $\operatorname{Escol(h)a~e~família~}$}

O processo de escolha do estabelecimento escolar já foi estudado por diversos autores filiados aos domínios da sociologia que têm se dedicado ao exame da educação e da educação escolar de crianças, adolescentes e jovens cujas famílias ocupam posições diferenciadas na estrutura socioeconômica de uma sociedade, tais como Nogueira (1998), Resende, Nogueira e Nogueira (2011), Viana (2005), Nepomuceno e Witter (2010), Oliveira e Melo-Silva (2010), Santos (2005) sendo a família fundamental ao longo desse processo seja de forma direta ou indireta.

A posição social ocupada pelo grupo familiar, o nível de escolaridade e a profissão dos pais podem influenciar as escolhas acerca das escolas a serem frequentadas pelos filhos de forma consciente ou inconsciente. Os trabalhos de Viana (2005) e Nogueira (1998) mostram de forma clara como esses fatores auxiliam na escolha dos estabelecimentos escolares através de estratégias ligadas à trajetória dos pais.

Quando se trata de adolescentes, porém, a participação dos pais na escolha pode se mostrar de forma clara e objetiva como também pode surgir de forma sutil, principalmente se o que está em jogo vai além do campo da educação e inclui as expectativas e desejos parentais quanto à futura ocupação dos filhos.

Os adolescentes que escolhem o ensino superior já passaram por todas as etapas da educação básica e, normalmente, já estão com idade entre 17 e 18 anos, ou seja, próximos à maioridade legal. Nesse caso, não é incomum que a escolha pelo curso e pela instituição de 
ensino seja feita de forma autônoma, isto é, pelos próprios adolescentes. Mas é fundamental considerar que mesmo nesses casos, autonomia não significa que a opção seja feita única e exclusivamente pelos adolescentes, mas deve-se levar em conta a influência dos pais, dos pares e da escola nesse processo que muitas vezes pode ocorrer de forma inconsciente e em diferentes formatos de acordo com a condição sociais das famílias.

Por outro lado, os adolescentes que escolhem ingressar em um curso técnico integrado ao ensino médio ainda estão dentro dos ciclos da educação básica e sua faixa etária normalmente está em torno de 14 ou 15 anos. A questão que se coloca aqui é que para alguns deles a escolha da profissão está se apresentando neste momento, longe da maioridade legal, e ainda distante do fim da educação básica. E, igualmente importante, o amadurecimento pessoal e psicológico desses adolescentes, as informações de que dispõem acerca de cursos e estabelecimentos de ensino, aliados ao capital cultural e às condições financeiras de famílias das camadas populares dificultam a construção de uma avaliação mais precisa da relação entre escola e do trabalho a ser exercido no futuro.

Lahire (1997) contribui para essa discussão ao discutir "o mito da omissão parental”. Através de dados levantados em pesquisa com famílias de camadas populares, o autor demonstra que ainda que os pais não sigam as estratégias das classes médias, como frequência em reuniões escolares, contato constante com professores, auxílio e checagem na elaboração das tarefas escolares, esses pais apresentavam alto nível de preocupação com a escolarização dos filhos, reconhecendo na escola a possibilidade de melhores condições de trabalho e de vida para os filhos. Nesse mesmo contexto Portes (2000) chama atenção para que se analise as famílias das camadas populares à luz de suas próprias estratégias, que ele chama de "trabalho escolar das famílias":

Dizem respeito à presença da ordem moral doméstica, à atenção para com o trabalho escolar do filho, ao esforço para compreender e apoiar o filho, à presença do outro na vida do estudante e a eterna aproximação dos professores, à busca da ajuda material e à existência e importância de um duradouro grupo de apoio construído no interior do estabelecimento escolar (PORTES, 2000, p. 66).

A essas circunstâncias é importante adicionar o conceito da "pedagogia do trabalho" trazido por Romanelli (1997), através da qual os pais das camadas populares socializam os filhos para assumirem precocemente a condição de trabalhadores embora continuando com a frequência à escola. Em trabalho sobre estudantes universitários das camadas populares Piotto (2007, p. 302) assinala que: 
[...] a presença do trabalho nas trajetórias desses estudantes, quer através de suas próprias experiências como trabalhadores, quer através da experiência de trabalho dos pais, parece-nos ter contribuído para desenvolver um modo peculiar de estar na escola e de relacionar-se com o estudo.

É importante, considerar, portanto, que a escolha pelo ensino técnico integrado não é tão somente uma escolha escolar, mas também profissional e que por isso mesmo, incorpora outras variáveis ligadas à família, à escola e ao mercado de trabalho. Nepomuceno e Witter (2010) elencam uma série de pressões e interesses internos e externos nesse processo e os dividiram em fatores políticos, econômicos, sociais, educacionais e familiares que estão em constante interação entre si e por isso mesmo influenciando as escolhas profissionais.

Dentre esses fatores, todos extremamente relevantes para a escolha profissional, ressalta-se o papel dos fatores familiares que, segundo os autores, "impõem uma parte importante no processo de impregnação da ideologia vigente" (NEPOMUCENO; WITTER, 2010, p. 16). A realidade objetiva na qual a família está inserida promove formas diferenciadas de articulação com os demais fatores, como as políticas de governo, globalização, desemprego, possibilidades de ascensão social, informações sobre as modalidades de ensino etc. Desse modo a família pode influenciar, ou às vezes determinar, a escolha por essa ou aquela profissão, como se o adolescente devesse "realizar aquilo que a família não realizou ou mesmo dar continuidade a tarefas já desenvolvidas por eles" (NEPOMUCENO E WITTER, 2010, p. 16).

E se a família é fator essencial tanto para a escolha do estabelecimento de ensino quanto pela escolha profissional, esta instituição não pode ficar fora das análises sobre o ensino técnico integrado ao ensino médio.

Como então as relações familiares, atravessadas pelas relações com os pares e a escola, influenciam o ingresso de adolescentes no ensino técnico integrado ao ensino médio e como se articulam com as aspirações e expectativas de pais e filhos quanto a essa modalidade de escolarização?

Nessa sequência, é necessário delimitar o que se entende por adolescente. Várias classificações foram elaboradas para determinar as faixas etárias às quais pertencem ${ }^{8}$. No caso do ECA (Estatuto da Criança e do Adolescente) é considerado adolescente aqueles com idade entre 12 e 18 anos, e será esse o critério utilizado pela presente pesquisa de modo a garantir um padrão para a escolha dos participantes, ainda que se compreenda - e concorde - que

\footnotetext{
${ }^{8}$ Watarai (2006) elenca três classificações: OIT (Organização Internacional do Trabalho), que classifica como adolescente o indivíduo entre 15 e 19 anos; OMS (Organização Mundial da Saúde), para quem adolescente é quem está na faixa etária entre 10 e 19 anos; e o ECA (Estatuto da Criança e do Adolescente), que considera adolescente aquele entre 12 e 18 anos.
} 
apesar de serem um importante instrumento, as classificações etárias não podem ser utilizadas como a única condição que determina as características das fases da vida.

Ao discutirem o que é juventude, Bourdieu (1983), León (2005), Sposito (2003), Pais (1990), Margulis e Urresti (2008), demonstram como ela ocorre de modo diferente para cada indivíduo, dependendo de inúmeros outros fatores determinados pela cultura e pelas condições históricas e sociais e que por isso mesmo apresenta constantes alterações sobre o significado do que é e o que significa ser jovem em determinado local e tempo, reflexões essas que também podem ser estendidas ao que é ser adolescente.

Adolescência e juventude aqui são trabalhadas como categorias distintas, mas que comungam de algumas condições e características que podem ser aproximadas por se entender, assim como Corti e Souza (2004), Fabbrini e Melucci (1992) e Melucci (1997) a adolescência como a porta de entrada para a juventude, sendo que, conforme os dois últimos autores, essa passagem nunca se extingue por completo, uma vez que suas memórias se prolongam por toda a trajetória dos indivíduos.

Através de Fabbrini e Melucci (1992) pode se compreender que a adolescência é caracterizada por ser uma fase da vida em que o indivíduo já se torna capaz de formular discursos sobre sua própria trajetória e a construir percepções sobre si, ainda que esses discursos estejam em constante (re)formulação e que os silêncios, bem como seu oposto, são formas do adolescente também se expressar.

Os autores trazem também a ideia de crise para o centro da discussão sobre a adolescência como processo de transformação física e subjetiva, quando passam a estabelecer novas relações consigo e com os outros, precisando reformular suas percepções.

Além dessa crise, Fabbrini e Melucci (1992) e Melucci (1997) podem ser aproximados da análise de Margulis e Urresti (2008) e das noções de moratória vital e social, ao demonstrarem a adolescência como momento em que existe todo um futuro de possibilidades e escolhas, que ao mesmo tempo em que acarreta mudanças que assustam os adolescentes também os instigam a viverem um momento em que todas as escolhas parecem ao mesmo tempo possíveis e reversíveis, além de permitir que eles próprios testem a si mesmos, bem como suas capacidades de efetuarem escolhas e de arcarem com suas responsabilidades.

Para o adolescente moderno [...] a relativa incerteza da idade é multiplicada por outros tipos de incerteza que derivam simplesmente dessa ampliação de perspectivas: a disponibilidade de possibilidades sociais, a variedade de cenários nos quais as escolhas podem ser situadas. [...]. A adolescência é a idade em que a orientação para o futuro prevalece e o futuro é percebido como apresentando um maior número de possibilidades. Uma perspectiva 
temporal aberta corresponde a uma forte orientação para a auto-realização, resistência contra qualquer determinação externa dos projetos de vida e desejo de uma certa variabilidade e reversibilidade de escolha. (MELUCCI, 1996, p. 9).

A mesma compreensão pode ser utilizada para analisar a relação que os adolescentes mantêm com o mundo do trabalho, que surge também como forma de testar e ou comprovar sua independência, sua capacidade própria e individual de se auto sustentar.

Bourdieu (1983 p. 113) destaca a forma como as relações de poder engendram a juventude", tornando-a "socialmente manipulada e manipulável” o que a caracteriza como sendo social e historicamente construída, assim como argumentam León (2005), Sposito (2003) e Pais (1990) e, portanto, não pode ser entendida como um todo homogêneo ${ }^{10}$ e linear.

São essas constantes transformações e reformulações de quem são os adolescentes que torna tão importante analisar as relações que eles mantêm com o mundo adulto, constituído pela família e pela escola, com os pares, representados pelos iguais, isto é por outros jovens, que se configuram como instâncias socializadoras que transferem e (re)criam valores e hábitos. A juventude e, no limite, a adolescência, portanto, se constrói na "luta entre os jovens e os velhos" (BOURDIEU, 1983, p. 113) e entre os jovens, como nos faz refletir Pais (1990).

$\mathrm{Na}$ convivência com grupos de pares, que inclui amigos com os quais os jovens convivem, eles constroem expectativas e aspirações ${ }^{11}$ particulares, podendo tanto se aproximar de seus pais quanto deles se afastar, conforme argumenta Bourdieu (1983, p. 118): "muitos conflitos de gerações são conflitos entre sistemas de aspirações constituídos em épocas diferentes". O adolescente, portanto, luta com e contra os pais, na medida em que se apropria, em menor ou maior grau dos sonhos e projetos deles, ao mesmo tempo em que busca pensar e decidir sobre e por si mesmo tal qual Fabbrini e Melucci (1992) apontam.

E se adolescência e juventude se constroem historicamente será que existe espaço para uma comunhão de expectativas entre pais e filhos? E qual é, hoje, o papel da escola em atender essas expectativas? Será que essa instituição consegue responder as expectativas de ascensão social criadas em relação ao futuro?

\footnotetext{
${ }^{9}$ É importante demarcar que apesar de vários autores aqui levantados trabalharem com o conceito de juventude acreditamos que, assim como esta, a adolescência também ocorre de forma heterogênea. Em momento posterior serão apresentados e discutidos textos que tratam especificamente da adolescência.

${ }^{10}$ José Machado Pais (1990, p. 151) ressalta dois eixos semânticos de juventude, um unitário que é "homogêneo se comparamos a geração de jovens com outras gerações" e outro eixo que é o da diversidade, que é "heterogêneo logo que a geração dos jovens é examinada como conjunto social com atributos sociais que diferenciam os jovens uns dos outros". É a esse segundo eixo que o presente trabalho irá se referir.

${ }_{11}$ Aspirações e expectativas devem aqui ser compreendidas como sendo, respectivamente, o desejo de conquista e a condição efetiva que os sujeitos acreditam que atingirão, conforme Souza e Lamounier (2010).
} 
O processo de escolha profissional ocorre durante um período em que o adolescente está construindo sua identidade enquanto indivíduo e, por isso, a participação da família e dos pares pode se fazer extremamente necessária, podendo ser, inclusive, determinante para ela.

Esse processo então envolve um conjunto de situações que podem ser paradoxais, tensas, conflituosas, mas também envolvem negociações, consensos, colaboração e apoio entre os atores/indivíduos: segurança x ansiedade, reprodução x diferenciação, família x pares, projeto individual x projetos familiares. $\mathrm{O}$ adolescente se vê imerso em um conjunto de desejos e pressões que não são somente suas, mas também dos familiares, amigos e da sociedade, ficando no limiar entre aquilo que deseja e aquilo que o obriga. Nessas circunstâncias, ele deve seguir o caminho dos pais ou aquele que escolher, reformulando as orientações parentais?

Segundo Santos (2005, p. 59) "a escolha profissional é uma oportunidade de provar lealdade à família e de cumprir com a sua missão não apenas individual, mas também familiar", de modo que a escolha do estudante pode significar a manutenção do status social da família ou uma ascensão ou queda social para todo o conjunto familiar.

Por outro lado, tendo em vista todos os capitais e instituições socializadoras que participam da formação dos alunos é preciso recordar Sposito (2003, p. 218) quando ela argumenta que "não se nasce aluno, alguém torna-se aluno", para entender que esses indivíduos, portanto, chegam à escola inseridos em uma rede de relações sociais nas quais estabelecem situações de pertencimento, individuação, subjetivação e identidade. Sendo assim já carregam consigo uma série de valores e capitais não escolares que se misturam, ou não, aos capitais transmitidos pela escola, e cada indivíduo conseguirá se apropriar desses capitais e internalizá-los na forma de habitus de formas diferentes.

A partir disso faz-se necessário um encontro direto com esses sujeitos, de modo a se investigar como são efetuadas as escolhas por determinado curso e quais as expectativas resultantes dessas decisões. Mas antes, indo ao encontro de Sposito (2003), é preciso saber quem é esse sujeito que se torna aluno ao longo das relações que estabelece entre esses espaços sociais e se a escola realmente pode ser um caminho para a conquista da ascensão social. 


\section{CAPÍTULO 3: OBJETIVOS, METODOLOGIA E TRABALHO DE CAMPO}

\subsection{Objetivos}

Esta pesquisa teve como objetivos examinar e analisar:

1. Como as relações familiares, escolares e entre pares influenciam o ingresso de adolescentes no ensino técnico integrado ao ensino médio no curso técnico em automação industrial do Instituto Federal de Educação, Ciência e Tecnologia de São Paulo, Campus Sertãozinho;

2. As articulações entre as aspirações e expectativas de pais e filhos quanto a essa modalidade de escolarização dentro do contexto social no qual estão inseridos, tais como local em que residem, profissão dos genitores e planos futuros relacionados ao ingresso no mercado de trabalho ou na universidade;

3. A incorporação e a reformulação das orientações parentais pelos filhos frente à escolha pelo curso de ensino técnico integrado ao ensino médio;

4. A importância do trabalho dos adolescentes para eles e para os pais;

5. O modo como vínculos com determinadas religiões articulam-se com o processo de escolarização;

6. As expectativas quanto ao futuro escolar e profissional dos adolescentes para eles e para seus pais.

\subsection{Metodologia}

Esta pesquisa é fundada em metodologia qualitativa, cujos dados foram coletados mediante realização de entrevistas aplicadas a número pequeno de sujeitos, como é de praxe em tais pesquisas. Portanto, não se tem a pretensão de produzir dados de cunho estatístico que possam ser generalizados, mas procura-se compor um quadro empírico e interpretativo para se analisar uma situação específica vivida por alunos da quarta série do curso de automação industrial. Apesar de tal limitação derivada do número de sujeitos, deve-se ressaltar que a análise dos objetivos propostos contribuirá para melhor entendimento das influências familiares na escolha do curso técnico, das avaliações dos filhos diante das orientações parentais, das expectativas de pais e filhos diante do ensino técnico, do modo como estes últimos avaliam essa modalidade de ensino e quais são suas aspirações profissionais. 
A coleta de dados foi feita por meio da realização de entrevistas gravadas e transcritas na íntegra, orientadas por um roteiro semi-estruturado (APÊNDICE A), elaborado a partir dos diversos aspectos que a pesquisa pretende examinar: perfil dos alunos, relações dos adolescentes com a família, com a escola, aspirações frente ao trabalho, expectativas futuras de iniciar atividade profissional e/ou de ingressar no ensino superior.

A utilização da entrevista permite estabelecer uma relação mais próxima entre a pesquisadora e os sujeitos da pesquisa, criando um rapport positivo que facilita a obtenção de informações. Além da entrevista a pesquisadora utilizou anotações em diário de campo com observações acerca do bairro, da moradia, quando a entrevista foi realizada na casa do participante, de sua postura e reações durante a entrevista e de seus eventuais questionamentos acerca da pesquisa. Essa forma adicional de coleta de dados permitirá compor um quadro de referências, comumente utilizadas em pesquisas de caráter qualitativo, que servirão de elemento auxiliar para melhor delimitar as condições socioeconômicas da família.

Paralelamente à coleta de dados com os alunos, um membro da gestão escolar da unidade de Sertãozinho, também foi ouvido e forneceu informações sobre a escola, os cursos e os alunos.

Após a finalização da coleta de dados, na fase final de análise dos resultados, foi realizado novo contato com os participantes para que eles se auto-identificassem de acordo com os critérios de cor estabelecidos pelo IBGE e também para responderem quais atividades estavam realizando após a conclusão do ensino médio.

A solicitação dessas informações após a realização das entrevistas foi motivada por duas considerações e para ampliar os dados coletados e a análise.

A primeira delas refere-se à cor da pele dos participantes. O critério cor não havia sido previsto como dado a ser coletado e incorporado ao material empírico e à análise. Por isso, não há nenhuma discussão teórica sobre a questão racial e sua relação com o processo de escolarização.

Em relação à cor foi escolhida a classificação utilizada pelo censo do IBGE, que utiliza os seguintes critérios de cor: branca, preta, parda, amarela e indígena e que se que se baseia na auto classificação dos sujeitos, conforme apontado por Osório (2003).

Como a seleção dos alunos foi feita de modo casual não houve preocupação em incluir ou não alunos não brancos. No entanto, após a entrevista constatou-se que havia quatro alunos brancos, dois pardos e seis pretos. Por isso solicitou-se aos sujeitos que se auto- 
classificassem em função dos critérios do IBGE para que essa classificação não ficasse submetida à avaliação da pesquisadora e a um possível viés subjetivo.

A autoclassificação da cor de cada um deles foi, portanto, incluída como um dado a mais para identificação dos sujeitos e para indicar que a maioria deles não é de brancos. Todavia, não se tem a pretensão de submeter esse elemento a uma análise mais apurada, já que como exposto acima, não houve discussão teórica para embasar uma interpretação da predominância de não brancos.

Acrescente-se ainda que tal predomínio ocorreu em uma única sala do curso de automação industrial e não se tem a intenção de generalizar essa constatação para o conjunto de alunos do Instituto. De qualquer modo, considerou-se importante incluir a cor dos alunos como dado que poderá ser melhor investigado em outras pesquisas para se avaliar se a presença de pardos e negros também ocorre em outros cursos do Instituto e mesmo em outras escolas.

Cabe ainda considerar que a maior quantidade de alunos pardos e pretos surgida no decorrer da pesquisa remete ao que DaMatta (1981, p. 168) denominou de anthropological blues, ou seja, os fatos insólitos e imprevisíveis que emergem no trabalho de campo e que ampliam e enriquecem os referenciais empíricos abrindo novos caminhos interpretativos. Assim, é possível “(...) recuperar este lado extraordinário e estático [imprevisto] das relações entre pesquisador/ nativo." (DAMATTA, 1981, p. 173). De modo semelhante, Fonseca (1999) também sugere que dados inesperados podem ser utilizados para alargar a análise dos temas pesquisados, introduzindo esses referenciais empíricos em novo corpo interpretativo.

Em segundo lugar, a solicitação para que os estudantes informassem se estavam trabalhando ou se haviam ingressado em algum curso superior também resultou do fato de que a análise dos dados ocorreu após eles terem concluído o curso no Instituto. Julgou-se importante oferecer tal informação para ampliar a análise.

Por se tratar de pesquisa com alunos que estão na faixa etária entre 15 e 17 anos, os pais ou responsáveis legais foram consultados para darem permissão a seus filhos para participarem da pesquisa. Foi explicado a eles, assim como aos adolescentes, os objetivos da pesquisa e a garantia de anonimato de seus filhos. Em seguida os pais ou responsáveis assinaram o Termo de Consentimento Livre e Esclarecido, em duas vias, uma das quais ficou em seu poder e a outra com a pesquisadora. Nesse documento constava o telefone da pesquisadora para contato com aqueles que o desejassem. 
Os participantes menores de idade também assinaram o Termo de Consentimento Livre e Esclarecido e aqueles com 18 anos assinaram, eles próprios, o Termo de Consentimento Livre e Esclarecido.

Os entrevistados não serão identificados, já que seus nomes foram alterados a fim de se manter seu anonimato e sua privacidade e, ao longo da pesquisa, eles gozaram de total liberdade para interromper sua participação caso sentissem necessidade.

Este projeto foi enviado ao Comitê de Ética da Faculdade de Filosofia, Ciências e Letras de Ribeirão Preto da Universidade de São Paulo e aprovado em 04 de março de 2013, conforme Parecer $n^{\circ} 210.659$ (ANEXO E).

\subsubsection{Análise dos dados}

Em um primeiro momento as entrevistas foram transcritas e analisadas de modo parcial, sendo levantados alguns aspectos relacionados aos objetivos propostos. Em momento posterior as entrevistas foram classificadas em dois eixos temáticos, família e escola, trabalho e expectativas analisados utilizando-se referenciais teóricos da sociologia da educação, apresentados na Introdução e no Capítulo 2. A análise procurou apreender os capitais cultural, econômico e social da família, como eles são transmitidos para os filhos, como estes efetuam a escolha do curso técnico e como organizam seus projetos quanto à futura carreira.

Procurou-se encontrar conteúdos em comum expressos pelos sujeitos, a fim de se organizar o conjunto das informações de modo integrado. Além dos conteúdos mais recorrentes e significativos das entrevistas, também buscou-se eventuais particularidades dos entrevistados, que os distinguissem dos demais. Esses elementos permitem caracterizar, por oposição, o conjunto dos sujeitos e ampliam o campo da investigação permitindo aprofundar a análise do material empírico. As notas do diário de campo contribuíram para complementar os dados das entrevistas, tanto oferecendo maiores informações obtidas nas entrevistas quanto relativizando as mesmas.

\subsubsection{Sujeitos da pesquisa: critérios de inclusão e escolha dos sujeitos}

Foram entrevistados dez alunos, cinco do sexo masculino e cinco do sexo feminino, matriculados na quarta série do curso técnico de automação industrial. A opção por alunos desta série é por ela corresponder ao último ano do curso e exigir estágio obrigatório em alguma empresa, o que coloca os estudantes mais próximos da realidade do mercado de 
trabalho. Desse modo, partiu-se do pressuposto que os alunos cursando a quarta série já têm conhecimento do ensino que estão recebendo e das possibilidades oferecidas pelo mercado de trabalho além da possível escolha por outra alternativa, qual seja, de prestar vestibular para ingresso no ensino superior.

A inclusão de dois grupos baseada na diferença de sexo permite a análise comparativa dos afastamentos e aproximações que levam homens e mulheres a ingressarem no ensino técnico, a(s) forma(s) como a família influencia mais ou menos cada um desses grupos e as particularidades das expectativas em relação ao futuro de cada um deles.

Os sujeitos foram escolhidos de modo casual a partir da lista de alunos regularmente matriculados no curso de automação industrial e buscou-se respeitar o limite de idade de até 18 anos no momento da entrevista. A partir dessa listagem os sujeitos foram selecionados através de contato com alunos regularmente matriculados no último ano do curso de automação industrial do Instituto. Todos os participantes são de camadas populares apesar desse não ter sido um critério prévio de seleção dos sujeitos.

\subsection{Trabalho de campo}

Logo no primeiro contato com os alunos houve a negação direta de participação de uma das adolescentes previamente selecionada, que foi posteriormente substituída através da indicação de outra participante. Houve três desistências, uma definitiva, em que um dos alunos preliminarmente escolhido acabou não podendo participar por falta de disponibilidade, e duas que acabaram ocorrendo após algum tempo do primeiro contato.

Um aluno cancelou a participação na véspera da data marcada para a entrevista por ter conseguido ingresso em um curso no período da tarde e por realizar estágio no período da manhã e uma aluna cancelou sua participação na véspera da entrevista, também por estar sobrecarregada. Esses dois participantes, porém, em novo momento, após o primeiro contato, já com os estágios finalizados, aceitaram integrar a pesquisa e aparecerão nos perfis com os nomes fictícios de Cíntia e Cássio.

No primeiro contato com os participantes e no início de cada entrevista foi exposta uma explicação breve sobre a condição da pesquisadora e dos objetivos e propósitos da pesquisa para diminuir possíveis dúvidas e explicitar a importância da participação do aluno. Foi solicitada autorização para a gravação da entrevista em áudio, bem como a explicitação do caráter sigiloso dos dados, ressaltando a alteração de nomes e outras informações que facilitem ou possibilitem a identificação dos participantes. 
Antes da realização de cada entrevista com os alunos, perguntou-se se queriam fazer a entrevista em suas casas ou em outro local de fácil acesso para eles e em que houvesse privacidade e ausência de interferência de outras pessoas. A determinação de deixar a critério do sujeito a escolha do local da entrevista liga-se à preocupação de deixá-lo à vontade em espaço físico onde não houvesse interferência de terceiros, sobretudo dos pais.

Todos, com exceção de Daniel, optaram por não fazer a entrevista em suas residências, mas em outros locais. Esse fato é relevante e será objeto de maiores explicações na exposição do capítulo 4. Perfis dos alunos. 


\section{CAPÍTULO 4: PERFIL DOS PARTICIPANTES DA PESQUISA}

Este capítulo inicialmente descreve os perfis dos alunos, apresentados na sequência em que as entrevistas foram realizadas, de modo a apresentar dados gerais como idade, modalidade de arranjo doméstico, condição econômica da família, escolaridade e ocupação dos pais, arranjos familiares, local de residência e cor da pele dos sujeitos, e cuja síntese pode ser vista nos quadros 1 e 2 abaixo. Algumas informações serão recuperadas e analisadas nos capítulos seguintes.

\begin{tabular}{|l|c|c|c|c|c|}
\hline & Daisy & Amanda & Sara & Vanda & Cíntia \\
\hline Idade & 17 & 17 & 18 & 18 & 18 \\
\hline Cor & Preta & Branca & Preta & Preta & Branca \\
\hline Arranjo familiar & Nuclear & Nuclear & Recomposta & Nuclear & Matrifocal \\
\hline $\begin{array}{l}\text { Tipo de escola em } \\
\text { que realizou o } \\
\text { ensino fundamental }\end{array}$ & Pública & Pública & Pública & Pública & Pública \\
\hline Ocupação do pai & Pedreiro & $\begin{array}{c}\text { Empreiteiro } \\
\text { civil }\end{array}$ & Pintor & Pintor & $\begin{array}{c}\text { Encarregado } \\
\text { em indústria }\end{array}$ \\
\hline Ocupação da mãe & Do lar & $\begin{array}{c}\text { Revendedora } \\
\text { comercial }\end{array}$ & $\begin{array}{c}\text { Auxiliar } \\
\text { contábil }\end{array}$ & $\begin{array}{c}\text { Auxiliar } \\
\text { de } \\
\text { limpeza }\end{array}$ & $\begin{array}{c}\text { Proprietária de } \\
\text { cantina }\end{array}$ \\
\hline
\end{tabular}

QUADRO 1 - Características socioeconômicas e familiares das participantes do sexo feminino

\begin{tabular}{|l|c|c|c|c|c|}
\hline & André & Daniel & Jonas & Cássio & Alan \\
\hline Idade & 18 & 17 & 18 & 18 & 18 \\
\hline Cor & Pardo & Branco & Pardo & Branco & Preto \\
\hline Arranjo familiar & Nuclear & Nuclear & Nuclear & Recomposta & Nuclear \\
\hline $\begin{array}{l}\text { Tipo de escola em } \\
\text { que realizou ou } \\
\text { ensino fundamental }\end{array}$ & Particular & Pública & Pública & Pública & Pública \\
\hline Ocupação do pai & Mandrilhador & Motorista & Pedreiro & $\begin{array}{c}\text { Profissional } \\
\text { liberal em } \\
\text { eletrônica }\end{array}$ & Pedreiro \\
\hline Ocupação da mãe & Do lar & Diarista & $\begin{array}{c}\text { Cuidadora } \\
\text { de idosos }\end{array}$ & Secretária & Diarista \\
\hline
\end{tabular}

QUADRO 2 - Características socioeconômicas e familiares dos participantes do sexo masculino

\subsection{Daisy, preta, 17 anos, família nuclear}

Daisy foi, no primeiro contato, a mais solícita a participar da pesquisa. Explicou a escolha por um local público, uma sorveteria com poucas pessoas presentes no momento da 
entrevista, por achá-la de mais fácil acesso para a pesquisadora, embora esta tenha insistido que não havia necessidade disso.

Porém após o término da entrevista, já com o gravador desligado, ela comentou que foi melhor termos conversado em local diferente da residência, pois lá estariam a mãe e a irmã e não teríamos um local silencioso e longe dos ouvidos das duas para conversarmos. Essa postura sugere que ela não se sentia à vontade para conversar com a pesquisadora sobre o curso em sua própria casa o que e levanta questões importantes acerca não só do espaço físico onde se realiza a entrevista, mas da necessidade de se falar com outro em local em que familiares não estejam presentes. Nesse sentido, essa escolha, que também ocorreu em outras entrevistas, remete a problemas metodológicos que precisam ser esclarecidos e aprofundados, e que serão retomados adiante.

Entre todos os entrevistados é a única que não reside na mesma cidade em que está situada a escola. Ela mora em uma cidade com 28.496 habitantes, com Índice de Desenvolvimento Humano Municipal de 0,725, conforme dados do IBGE (2010b), e que também integra a região administrativa de Ribeirão Preto.

Daisy mora com os pais e duas irmãs, uma mais velha de 20 e a outra mais nova de 15 anos. O pai, 43 anos, não completou o ensino fundamental e trabalha como pedreiro, sendo o único responsável pelo sustento da casa e com rendimento entre dois e três salários mínimos ${ }^{12}$. Ao definir sua condição socioeconômica, ao invés de utilizar os termos comuns como "pobre", "rica", "classe média", "classe baixa" ela se apropria da expressão próspera, cunhando um sentido que condiz com as expectativas expostas por ela ao final da entrevista, o de alguém que busca o crescimento e o autodesenvolvimento.

A mãe, 40 anos, completou o ensino fundamental e não exerce atividade remunerada, porém já trabalhou como doméstica e, segundo Daisy, abandonou a profissão a pedido do marido, por ciúmes dele e também porque percebia que na cidade não havia valorização desse tipo de serviço. A irmã mais velha formou-se recentemente em técnica em Administração por uma instituição de Sertãozinho - não a mesma em que Daisy estuda - trabalhou no setor terciário em uma lanchonete, porém, desde que se formou está à procura de emprego na área administrativa. A mais nova cursa o primeiro ano do ensino médio em escola estadual na cidade onde a família reside e chegou a prestar prova para ingressar no Instituto mas não foi aprovada.

\footnotetext{
${ }^{12}$ No momento das entrevistas o salário mínimo nacional correspondia a $\mathrm{R} \$ 678,00$.
} 
Daisy descreve bom relacionamento com todos em sua casa, porém em sua fala faz ressalvas à irmã caçula, com quem tem algumas desavenças, causadas por uma sensação de que a caçula tomou seu espaço.

A mais próxima a ela é a mãe, a quem se refere como sua melhor amiga, e de quem recebe conselhos e com quem tem mais liberdade para conversar sobre relacionamentos, amizades e problemas. Com o pai sua relação já é mais afastada, conversando com ele apenas o essencial, dado o fato de achá-lo mais rígido, e com isso se sentir acanhada em comentar determinadas coisas com ele. A família, no momento da entrevista, se reunia somente nos finais de semana. Devido ao horário do estágio e das aulas ela se encontrava durante a semana somente com sua mãe e a irmã mais velha no período da tarde, momento em que nem o pai e nem a irmã caçula estavam presentes.

No momento da entrevista, ela estava completando os créditos do estágio obrigatório para formação no curso técnico em uma empresa de automação industrial em Sertãozinho de forma não remunerada, na qual era responsável pela inspeção final da qualidade dos produtos fabricados. Essa contribuição da escola para o trabalho é, segundo ela, muito importante por permitir que os alunos conheçam a prática da profissão, além da oportunidade de ser efetivada pela empresa.

\subsection{André, pardo, 18 anos, família nuclear}

O local escolhido pelo participante foi o próprio Instituto, porém dada a grande quantidade de pessoas que circulavam nas áreas comuns e na falta de sala de aula vazia disponível, a entrevista foi realizada na praça em frente à escola.

A opção por ser entrevistado fora da residência dos pais repõe a postura de Daisy, primeira entrevistada, e recoloca a mesma questão. Por que esses dois adolescentes não quiseram ser entrevistados na casa dos pais? E novamente, a mesma questão é posta em causa para pontuar a recusa em falarem com a pesquisadora no espaço doméstico.

No início da entrevista foi necessária uma intervenção mais efetiva da pesquisadora, de modo a reformular as perguntas ou criar formas de instigar o participante a se aprofundar mais em suas respostas, uma vez que ele respondia de forma direta e vaga às perguntas formuladas. Porém, no desenrolar do processo, e estabelecido o diálogo, André conseguiu ficar mais à vontade para desenvolver suas respostas.

O silêncio de André remete a duas considerações. A primeira refere-se ao próprio trabalho da pesquisadora que, frente ao primeiro interlocutor do sexo masculino, pode ter 
apresentado dificuldades em se conectar com a mesma facilidade que ocorreu com a primeira participante do sexo feminino. Mas, para além das dificuldades subjetivas da pesquisadora há que se fazer referência à obra de Fabbrini e Melucci (1992) em que ressaltam a adolescência como uma fase marcada pelas primeiras tentativas dos sujeitos de falarem sobre si mesmos, o que traz consigo um momento de profunda introspecção para que as palavras possam aflorar durante determinado tipo de conversação.

André mora com o pai de 53 anos, a mãe de 46 anos e a irmã mais nova de 16 anos no centro da cidade em que está localizado o Instituto. O pai exerce a função de mandrilhador, é o único responsável pelo sustento da família e tem rendimento de aproximadamente seis salários mínimos e a mãe tem até o nono ano do fundamental e trabalha em casa. O pai estudou até o ensino médio, fazendo posteriormente o curso técnico para a função que exerce atualmente.

André diz manter boa relação com todos os membros da família, sendo que com a irmã essa relação melhorou após eles crescerem e a diferença de pensamentos e gostos ter diminuído. Tem mais proximidade com o pai, com quem se sente mais à vontade para conversar sobre sua vida particular, mantendo com ele uma relação mais próxima nos finais de semana, tendo em vista que o pai trabalha de dia e ele estuda à noite. A proximidade com 0 pai é explicada por André pelo fato de ambos serem homens, e é pelo mesmo motivo que suas conversas com a mãe não costumam passar por temas como relacionamento ou "vida social", como o próprio André define, por achar a mãe mais ingênua que o pai.

No momento da entrevista ele estava cumprindo o estágio obrigatório de forma não remunerada na mesma empresa de automação industrial em que Daisy e desempenhava principalmente a função de organizar e separar os produtos entre os setores de montagem. Ao contrário de Daisy, que conseguiu o estágio através dos avisos da escola sobre a existência da vaga, André obteve o estágio através do capital social de seu pai que tem um amigo funcionário da empresa e que interferiu para que ele estagiasse na empresa.

\subsection{Amanda, branca, 17 anos, família nuclear}

A entrevista com a participante foi marcada duas vezes; na primeira ela não compareceu devido a um erro de comunicação entre entrevistada e pesquisadora e que mais tarde foi esclarecido quando foi realizada a entrevista. A escolha em fazer a entrevista em uma praça foi da participante que ao fim da entrevista, já com o gravador desligado, disse ter sido a melhor opção, pois sua mãe estaria em casa naquele momento e ela talvez não se 
sentisse a vontade para relatar tudo o que disse. Novamente, encontram-se aqui os mesmos obstáculos postos pelos dois primeiros entrevistados quanto a falarem com a pesquisadora na casa dos pais.

Amanda demonstrou logo no primeiro momento da entrevista grande medo de errar, foi a única a propor que as perguntas fossem lidas antes, com o gravador desligado, para que ela pudesse ouvi-las e pensar sobre as possíveis respostas, "porque vai que eu falo coisa errada". Mas após uma breve explicação sobre porque isso não poderia ser feito ela aceitou iniciar sem essa "sinopse". É importante relatar, porém, que em vários momentos da entrevista ela perguntava “é isso que você queria saber?" ou "respondi certo?".

Ela tem 17 anos e mora com os pais e a irmã mais velha na mesma casa de um bairro que recebe, como muitos outros, o nome de Cohab. Tais bairros ficam próximos uns dos outros e levam, em frente ao nome "Cohab" um número que os diferencia.

O pai e a mãe são os responsáveis pelo sustento da família, com uma renda familiar que gira em torno de cinco salários mínimos, porém, a entrevistada não tinha muita certeza, afirmando que poderia ser mais. O pai, 37 anos, tem ensino médio incompleto e é proprietário de uma empresa de construção civil em Sertãozinho com parceria com uma construtora de Ribeirão Preto. A mãe, 39 anos, terminou o ensino médio e tem curso técnico em administração trabalhando como revendedora comercial nas cidades da região. A irmã de Amanda também tem curso técnico em administração e apesar de trabalhar não ajuda no sustento da casa.

No momento da entrevista estava realizando o estágio atuando na limpeza de sensor capacitivo usado em automação para detecção de materiais como vidro, papel, controle de líquidos em equipamentos etc. Como o estágio não é remunerado ela vende trufas, o que garante cerca de oitenta ou noventa reais por mês em média. Ela teve bolsa auxílio da escola no primeiro ano, e estava tentando de novo esse ano a de auxílio transporte.

\subsection{Daniel, branco, 17 anos, família nuclear}

Daniel foi o único a optar por realizar a entrevista em sua própria residência. A casa é pequena mas, conforme ele esclareceu, era maior e foi dividida em duas para abrigar os avós em uma delas. As paredes e o chão da garagem estavam sem pintura ou piso, deixando a parte do reboco e cimento aparentes. Passada a garagem, à direita é a sala, na qual há dois sofás dispostos um de frente para o outro cada qual encostado na parede, deixando entre eles somente o espaço suficiente para passagem e delimitado pela largura da porta de entrada. 
Ainda na sala, do lado oposto à porta, há uma estante que ocupa quase a parede toda, com televisão, vários livros e uma grande Bíblia a mostra.

Apesar de não passar da sala, consegui observar a cozinha, em um extremo e que não parecia muito maior que a sala. No outro extremo, ocupando o outro lado da sala ficavam banheiro e os quartos, mas consegui ver apenas duas portas do que pareciam ser os quartos, mas não é possível afirmar a quantidade exata dos cômodos. No tempo em que estive na casa ficamos sozinhos; a irmã dele não estava e a mãe encontrava-se no salão de beleza, provavelmente se arrumando para o evento religioso que tinha à noite ${ }^{13}$.

Durante toda a entrevista ele sorriu, mesmo nos momentos em que pudesse se esperar algum sentimento de tristeza ou de mágoa. A religião, mais especificamente a crença e sua atividade como Testemunha de Jeová influenciam as relações que ele mantem com seus familiares, com a escola e seu futuro, como será analisado adiante.

Daniel mora em um dos bairros da Cohab e quando criança morou em outro conjunto da mesma cooperativa, mas o pai vendeu a casa para pagar as dívidas contraídas com a construção de uma casa para os avós. Com isso a família mudou-se para a casa que ocupam agora dividindo-a ao meio e metade ficou com eles e a outra metade para os avós.

Inicialmente informou que residia com a mãe, o pai e a irmã mais velha. Porém, mais adiante informou que o pai está detido pela terceira vez por tráfico de drogas. Todavia essa questão será melhor discutida adiante.

Daniel trabalha desde os 12 anos, tendo conseguido seu primeiro emprego na oficina mecânica do tio onde ganhava cerca de cem reais por mês. A busca por esse primeiro emprego partiu dele próprio que diz que se sentia mal em ter que pedir dinheiro para a mãe todas as vezes que queria algo e por não achar justo ela trabalhar tanto e ter que gastar com ele. Além disso, relata não gostar de ficar "à toa" em casa, e que isso deixa-o cansado e que gosta de trabalhar.

No momento da entrevista ele estava trabalhando meio período em uma empresa de instalação de vidros, portas e esquadrias de alumínio, ganhando vinte reais por dia. Sua mãe, 50 anos, é doméstica e faz alguns serviços de costura, mas ele não sabe ao certo qual seu rendimento mensal, mas acredita que seja em torno de duzentos reais por serviços de faxina semanais. Mas não sabe quanto ela ganha pelo trabalho de faxina em outras casas e com os serviços de costura. Como forma de auxílio a família conta com o Bolsa Família e tinha

\footnotetext{
${ }^{13}$ No dia 26/03/2013 à noite, mesmo dia em que a entrevista foi realizada, Daniel não foi à escola, pois houve a comemoração da morte de Jesus Cristo, segundo a crença dos Testemunhas de Jeová.
} 
entrado com ação através de um advogado - pago pelo avô paterno - para tentarem receber o auxílio reclusão, devido à prisão do pai.

Daniel não soube dizer a escolaridade de seus pais, mas sabe que é baixa e que por isso eles sempre o incentivaram a estudar para ter uma vida melhor que tiveram.

\subsection{Jonas, pardo, 18 anos, família nuclear}

A entrevista aconteceu no dia em que o participante completava 18 anos e foi realizada na própria sala em que os alunos têm aula. A experiência foi importante para que fosse possível notar a má qualidade acústica da sala, tanto no momento da entrevista quanto durante o processo de transcrição. Nesse caso, os ruídos e vozes da sala ao lado, separada apenas por uma fina parede de eucatex, dificultaram o entendimento das falas. Isso levanta a questão, que inclusive foi apontada por Daniel, sobre o caráter negativo que essa falha acústica provoca nos estudantes durante as aulas.

Jonas reside na casa atual há cinco meses, já tendo morado em bairro diferente e durante um período de um ano e meio residiu em uma cidade próxima. Mora com o pai, 54 anos, a mãe, 41 anos, e dois irmãos caçulas, de 15 e 12 anos, e apesar de trabalhar no depósito de uma empresa de materiais para construção, ganhando $\mathrm{R} \$ 447,00$, não ajuda nas despesas da casa. O salário é utilizado para suas próprias contas, compra de roupas e pagamento do computador.

O pai e a mãe têm ensino fundamental completo e são responsáveis pelo sustento da casa com um rendimento total de aproximadamente $\mathrm{R} \$ 2.000,00$. O pai é pedreiro e a mãe, que antes tinha seu próprio salão de cabeleireira, agora é cuidadora dos avós de Jonas, recebendo uma quantia mensal por isso.

Jonas conseguiu seu primeiro emprego há cerca de sete meses no cargo de aprendiz junto ao sistema de cadastros de jovens da Prefeitura de Sertãozinho. Como seu cargo é em um depósito de loja de materiais de construção e não está relacionado à área de automação, ele ainda tinha que conseguir outro local para realizar o estágio obrigatório do curso. A motivação para a busca do primeiro emprego foi uma necessidade de independência financeira frente aos pais. 


\subsection{Sara, preta, 18 anos, família recomposta}

Os primeiros contatos com Sara foram feitos alguns dias antes da entrevista. A princípio ela era uma das participantes com maior disponibilidade de tempo, uma vez que não trabalhava, sendo responsável apenas por cuidar da irmã caçula, de um ano e dois meses. Um tempo antes da entrevista, porém, ela conseguiu emprego em uma firma de advocacia e apesar de querer participar da pesquisa não sabia quando isso seria possível. Dado esse contexto a entrevista com Sara foi marcada pela própria participante, que me contatou no dia vinte e sete de março à noite por telefone, para dizer que na manhã seguinte estaria sozinha no escritório de advocacia onde trabalhava e que poderia realizar a entrevista no horário de trabalho, pois devido a um feriado religioso, estaria apenas cumprindo horário de trabalho, sem atividades obrigatórias.

A entrevista possibilitou o contato com um arranjo familiar diferente dos adolescentes até então entrevistados, já que sua família é recomposta. Como desde o começo da entrevista Sara demonstrou grande proximidade com o padrasto resolvi incluí-lo nas perguntas sobre seus pais.

Sara mora com a mãe, o padrasto e a irmã caçula em bairro periférico da cidade de Sertãozinho. Os pais são separados há doze anos, sendo que ao contrário da mãe, vivendo em união consensual há dois anos, o pai não contraiu segundo relacionamento.

Segundo Sara o divórcio dos pais não afetou seu desenvolvimento escolar uma vez que ela percebia na época a importância dos pais se separarem e vê a mãe, atualmente, como alguém bem sucedida, que reconstruiu sua vida pessoal e profissional, apesar das adversidades. É com a mãe que ela mantém a relação afetiva mais próxima e é a pessoa mais citada por Sara ao falar sobre os fatores que podem ter influenciado sua trajetória escolar de forma mais positiva, apesar de tanto o pai quanto o padrasto também figurarem como personagens importantes em sua história.

O pai é trabalhador autônomo, exercendo a atividade de pintor, possui ensino fundamental completo, ganha em torno de cinco salários mínimos por mês, valor que pode variar uma vez que é trabalhador autônomo, e paga pensão mensal para a filha. A mãe de Sara é auxiliar contábil em uma rede de supermercados regional, tem ensino médio completo, e sua renda, acrescida da pensão que o ex-marido paga, gira em torno de três salários mínimos. O padrasto de Sara é comprador na mesma rede de supermercados em que sua mãe trabalha, realizou pós-graduação em faculdade particular no curso de gestão integrada e recebe em 
torno de seis salários mínimos, valor também flutuante uma vez que recebe por comissão de compra e venda.

Apesar de morar com a mãe, Sara tem uma relação relativamente próxima ao pai, que é quem a leva e traz do Instituto todos os dias, além de saírem juntos aos domingos para irem à feira, supermercado ou simplesmente passearem juntos. Apesar da proximidade, Sara confessa que suas conversas com ele não são tão profundas como as que têm com a mãe e que o pai a ajuda muito financeiramente. Já a relação com o padrasto, seis anos mais novo que sua mãe, se dá nos momentos de lazer, assistindo filmes juntos, saindo para fazer compras e que por ele ser mais novo que os pais dela eles são mais "molecões" quando estão juntos.

Com a irmã, fruto da relação da mãe com o padrasto, Sara é só elogios e carinho. Segundo ela, o nascimento da irmã foi importante para que pudesse amadurecer e aprender a dividir o espaço e a atenção com ela, além de aprender a cuidar de outra pessoa, já que antes de começar a trabalhar era ela a responsável por todas as atividades diárias com a irmã, como dar banho, preparar e dar comida, pô-la para dormir, enquanto a mãe estava trabalhando.

\subsection{Vanda, preta, 18 anos, família nuclear}

Vanda não havia sido previamente selecionada para a realização das entrevistas, que foi feita segundo consulta à lista de alunos regularmente matriculados no curso de automação industrial. Porém, como uma das alunas não aceitou participar da pesquisa, ela foi contatada por intermédio da primeira participante, Daisy, e concordou em ser entrevistada. Vanda e o último participante, Alan, foram os únicos selecionados através de indicação dos próprios colegas de curso e ambos preenchiam os requisitos expostos no item sobre Metodologia para inclusão na pesquisa.

A estudante faz curso técnico em elétrica de manutenção em outra instituição no período da manhã, trabalha nessa escola no período da tarde e estuda no Instituto à noite. Tendo em vista suas atividades, precisou desmarcar as entrevistas em cima da hora ao menos uma vez. Também por causa de seu horário a entrevista foi marcada para as 18 horas no próprio Instituto em um dia que a primeira aula seria livre.

Essa participante mora com os pais em um dos bairros da Cohab. Seu pai, 48 anos, cursou até o quinto ano do ensino fundamental, trabalha como pintor autônomo, com uma renda de aproximadamente dois salários mínimos, valor flutuante uma vez que é autônomo. Vanda não soube precisar exatamente até qual série sua mãe, 48 anos, estudou, porém afirmou 
que ela tem ensino fundamental incompleto e trabalha como auxiliar de limpeza, ganhando entre um e um salário mínimo e meio.

A relação com os pais é descrita como boa e aberta ao diálogo, tendo abertura para tratar sobre variados assuntos e apesar de ter muita proximidade com a mãe, com quem descreve uma relação de união e apoio, sua relação é melhor e mais próxima com o pai. Ela explica essa proximidade pelo que denomina de gênio dela e do pai que é mais tranquilo enquanto a mãe é mais explosiva. O pai, assim como a mãe, é descrito como alguém que a ajuda e apoia. No referente à escolarização, Vanda ressalta que sua mãe sempre teve maior rigidez e participação em comparação com seu pai. Já o exame das tarefas era realizado principalmente por sua irmã, que a acompanhava quando criança.

Além dos pais, outra importante presença familiar é sua irmã mais velha, 25 anos, que já é casada. Quando perguntei sobre a relação dela com a irmã, Vanda começou a chorar e permaneceu ainda um bom tempo abalada e com lágrimas nos olhos, vacilando um pouco na fala em outros momentos quando o assunto remetia à irmã. Esse sentimento se dá pelo fato de ter sido muito próxima da irmã quando moravam juntas na casa dos pais, e agora sente sua falta uma vez que já não conseguem mais se ver ou se falar todos os dias devido a suas atividades profissionais e escolares.

O sofrimento de Vanda em relação a sua separação da irmã pode ser compreendido pelo fato de ter sido a irmã quem cuidou dela na infância enquanto os pais trabalhavam e ainda na adolescência passavam muito tempo juntas conversando sobre assuntos que ela não se sente à vontade para conversar com os pais, como por exemplo, questões ligadas à sexualidade. A proximidade da relação com a irmã remete aos vínculos entre irmãos, sobretudo com os mais velhos, que são fonte de informações e de orientações e, assim, contribuem para a socialização dos irmãos mais novos, além de oferecerem suporte emocional a estes.

Ela teve seu primeiro emprego aos 16 anos num escritório de advocacia e no momento da entrevista fazia parte de um projeto de aprendizes que integra um convênio entre empresas da cidade e uma instituição de ensino técnico, que não é o Instituto. O projeto oferece aos alunos participantes a oportunidade de frequentarem curso técnico na instituição de ensino em um período e em outro exercerem trabalho remunerado na empresa patrocinadora.

Além da remuneração de seu trabalho, que é em torno de um salário mínimo e meio, Vanda também recebe desde o ano passado a bolsa auxílio da escola, completando assim seus rendimentos, o que permite a ela arcar com seus próprios gastos e eventualmente ajudar seus 
pais em casa. $\mathrm{O}$ trabalho representa para ela a oportunidade de alcançar certa independência financeira, além, da oportunidade de conquistar experiência e responsabilidade.

\subsection{Cíntia, branca, 18 anos, família matrifocal}

O primeiro contato com Cíntia foi feito em março de 2013, assim como com todos ${ }^{14}$ os outros participantes, e a entrevista chegou a ser marcada, porém ela cancelou-a na véspera. Cíntia alegou, na época, que apesar de ter interesse em participar da entrevista, estava sobrecarregada com as atividades da escola e que não dispunha de tempo. Porém, como ela disse ter interesse em participar retomei o contato e conseguimos marcar a entrevista.

Cíntia vive com a mãe em bairro periférico da cidade de Sertãozinho desde que os pais se separaram há oito anos. Sua mãe, 36 anos, estudou até o sétimo ano do ensino fundamental, trabalhou muito tempo como doméstica, mas atualmente é proprietária do ponto de uma cantina em uma escola e Cíntia também trabalha com ela. A renda da mãe gira em torno de dois e quatro salários mínimos por mês, acrescido dos $\mathrm{R} \$ 950,00$ que seu pai paga de pensão mensalmente. Na época em que sua mãe trabalhava como doméstica, logo após o divórcio, Cíntia ajudava-a eventualmente em algum serviço, indo com ela nas casas de família ou clubes para trabalhar com a mãe como doméstica e ela diz se orgulhar muito desse período, pois foi quando conseguiram o dinheiro para comprar um carro e Cíntia abriu mão de sua festa de aniversário de 15 anos para que alcançassem o sonho do carro próprio.

O pai, 40 anos, também tem até o sétimo ano do ensino fundamental, trabalha como encarregado em uma empresa e ganha aproximadamente quatro salários mínimos. Seu pai casou-se novamente há sete anos e Cíntia diz conversar com a esposa dele, mas sem muita proximidade ou confiança.

Esse afastamento com a atual esposa do pai talvez seja reflexo da sua própria relação com ele que era muito próxima e afetiva quando criança e antes do divórcio mas tornou-se distante e superficial na adolescência.

Como sua mãe recebe o boletim ela diz não ter como esconder dela eventuais notas baixas, mas que as esconde de seu pai, dizendo para ele que vai bem na escola mesmo quando isso não é verdade. Diz ainda que tem dificuldade em conversar com ele mesmo assuntos referentes diretamente aos dois, não se sentindo próxima o suficiente para dizer o que pensa ou sente.

\footnotetext{
${ }^{14}$ Exceto no caso de Alan que foi indicado por Daisy e Cássio no segundo semestre de 2013.
} 
Seu primeiro contato com o trabalho aconteceu aos 11 anos quando começou a desfilar como modelo por influencia de sua mãe que também havia trabalhado como modelo antes de se casar. Cíntia conta que sua mãe sempre esteve a seu lado, estimulando-a a se manter saudável mesmo quando começaram as pressões para que Cíntia se adequasse aos padrões de beleza do mundo da moda.

Além dessa atividade que Cíntia ainda mantem, trabalha na cantina de sua mãe desde os 17 anos com carteira assinada, porém não recebe salário fixo. Sua mãe paga seus gastos e lhe dá dinheiro sempre que precisa. Cíntia também já terminou o estágio obrigatório do curso de automação na mesma empresa em que trabalham Daisy, André, Amanda e Alan. Assim como seus amigos já relataram, para Cíntia o trabalho também significa maior independência financeira.

\subsection{Cássio, branco, 18 anos, família recomposta}

Assim como Cíntia, Cássio também precisou desmarcar a primeira entrevista no dia anterior à data marcada por ter conseguido estágio no período da tarde e fazer curso técnico de instrumentação em outra instituição no período da manhã.

Retomei contato com Cássio no segundo semestre de 2013 e marcamos a entrevista. Em todas as vezes que falei com Cássio, por telefone ou pessoalmente, ele sempre foi extremamente educado e com dicção e português impecáveis. Tem uma fala calma e contida, fez aulas de teatro durante quatro anos e gosta muito de ler, fazendo questão de dizer que tem em casa 84 livros, já tendo lido todos e que esse número não é nem a metade do que ele ainda pretende ler.

Cássio mora com os pais no mesmo bairro da Cohab onde reside Amanda e antes disso morou na casa de sua avó em outro bairro da Cohab até pouco mais de um ano de idade. Esse período na casa da avó ocorreu pois Cássio nasceu prematuro, com 6 meses e 35 dias e precisou de cuidados mais intensos nos primeiros meses de vida.

Seu pai foi casado anteriormente, tendo dois filhos da primeira união bem mais velhos que Cássio. Um tem 36 e o outro 32 anos e, além deles, o pai de Cássio tem uma filha mais velha, de 42 anos, da época em que era solteiro. A relação de Cássio com os irmãos é distante, principalmente com os dois mais velhos, mantendo um relacionamento um pouco mais próximo com o irmão de 32 anos, que visita o pai de vez em quando.

O pai de Cássio, 59 anos, tem ensino médio completo e cursos técnicos em contabilidade, eletrônica e mecânica, e trabalha como profissional liberal na área de 
eletrônica. Sua mãe tem 42 anos, também completou o ensino médio e trabalha como secretária em um escritório de psicologia. Juntos, os pais de Cássio tem uma renda de aproximadamente quatro salários mínimos, valor que varia pelo fato de o pai ser autônomo.

Se Cássio não tivesse ingressado no Instituto iria para alguma escola da rede estadual, embora seu desejo fosse, caso não passasse na prova de ingresso do Instituto, cursar o ensino médio em uma escola particular de Sertãozinho, mas que por motivos financeiros ele sabe que não teria sido possível.

Em relação ao trabalho Cássio teve sua primeira experiência durante o estágio, sendo o único dos entrevistados a realizar estágio remunerado, ganhando $\mathrm{R} \$ 450,00$. Ele conseguiu o estágio na empresa de um amigo da família que, desde o primeiro ano de seu ingresso no Instituto, avisou-o para procurá-lo que ele o ajudaria, já que a família de Cássio havia auxiliado-o muito no passado. Essa forma de ajuda mostra a importância do capital social familiar para a conquista de determinadas posições, mesmo entre as camadas populares.

\subsection{Alan, preto, 18 anos, família nuclear}

Alan foi o último participante a ser entrevistado e o último a ser escolhido. Daisy, Cássio e Jonas indicaram Alan, dizendo inclusive que no primeiro contato que fiz com a escola ele já havia ficado interessado em participar da pesquisa, informação a que só tive acesso quando conheci Alan, um dia antes da entrevista.

Ele mora com os pais e duas irmãs, de 19 e 13 anos em um bairro periférico de Sertãozinho, mas nasceu em uma cidade de porte médio da grande São Paulo, e sua família mudou-se para o interior quando ele tinha três anos, fugindo da violência da região da capital paulista. Em um primeiro momento, eles se fixaram em uma pequena cidade da região de Ribeirão Preto onde sua avó vive, porém, por ser uma cidade menor seus pais não encontraram emprego.

Há seis anos, quando seu pai conseguiu um emprego melhor em Sertãozinho a família mudou-se novamente para essa cidade. Esse período de mudanças, principalmente a primeira em direção ao interior, provocou uma queda no rendimento escolar de sua irmã mais velha, que chegou a ser reprovada duas vezes no terceiro ano do ensino fundamental. Essas reprovações no início da vida escolar talvez expliquem porque o rendimento escolar de Alan é superior ao da irmã mais velha, já que ele não sofreu as mesmas dificuldades no inicio de sua escolarização, período que para alguns autores, como Lahire (1997) é fundamental para o bom ou mal desempenho de toda a trajetória escolar do aluno. 
Seu pai tem 44 anos e trabalha como pedreiro; sua mãe tem 41 anos, é diarista, e ambos têm ensino médio incompleto. Alan não soube precisar o rendimento dos pais pois o salário de ambos é muito variável, porém, ele acredita que seja um pouco mais do que dois salários mínimos.

Suas irmãs e ele não trabalham, ficando a cargo dos pais todas as despesas da família. Alan recebe bolsa auxílio da escola e o dinheiro recebido, como parece ser a norma entre os entrevistados, fica com os próprios adolescentes, sendo usado para suas necessidades e não para o sustento familiar.

É importante ressaltar que, exceto por sua experiência no estágio e outros pequenos bicos, como ajudante de manutenção de eletrodomésticos durante as férias escolares de seu segundo ano no Instituto, e quando ajudou o pai no trabalho de pedreiro, Alan nunca trabalhou.

\subsection{Os percalços do trabalho de campo}

Do exame dos dados apresentados pode-se discutir as dificuldades práticas da realização das entrevistas como a própria escolha pelo horário e local, que dependiam da disponibilidade e desejo dos participantes. Os casos de Cássio, Cíntia, Amanda, Vanda e Sara são exemplares dessas dificuldades.

No caso dos dois primeiros a dificuldade para entrevistá-los decorreu inicialmente da falta de tempo devido a seus compromissos de estudo e trabalho, fazendo com que desmarcassem suas participações na véspera da entrevista. Já com Amanda houve um erro de comunicação da pesquisadora que não havia compreendido a necessidade de confirmação da data da entrevista, que acabou precisando ser adiada em uma semana.

Vanda preferiu fazer a entrevista no intervalo entre seu emprego e as aulas no Instituto, optando por realizar a entrevista na própria escola de modo a não atrapalhar seu horário de aula. Sara avisou a pesquisadora sobre maior flexibilidade de horário no seu trabalho, em decorrência de um feriado, marcando a entrevista em seu ambiente de trabalho. Apesar de uma apreensão inicial da pesquisadora por essa escolha, a entrevista ocorreu sem grandes interrupções e contou com total dedicação da participante que se preocupou em responder cada pergunta da forma mais completa possível.

As escolhas pelos locais de realização da entrevista ainda levantam questionamentos sobre o fato de apenas um dos entrevistados, Daniel, ter sido entrevistado em sua residência. A falta de mais entrevistas nas moradias remete a algumas questões, como a não possibilidade 
de conhecimento e descrição das condições das casas dos participantes que poderiam trazer mais elementos para a análise.

Por outro lado, o fato das nove outras entrevistas terem sido feitas em locais públicos no Instituto, na praça frente a ele, na praça central do município, no local de trabalho e em uma sorveteria - não acarretaram prejuízo para a coleta de dados. Ao contrário, os sujeitos sentiram-se à vontade para conversarem sobre suas vivências em relação à escola, ao trabalho, à família e ao futuro.

E como eles próprios explicitaram, o fato de estarem longe dos familiares, assegurou maior liberdade para falarem sobre temas que talvez fossem mais difíceis de serem abordados no espaço doméstico, como Daisy e Amanda esclareceram.

Além disso, nos casos de Vanda, Sara e Cíntia a escolha pelo local da entrevista teve estreita relação com a disponibilidade de horário, de modo que elas puderam conciliar trabalho com a entrevista.

Nota-se, portanto, entre os entrevistados, vivências da adolescência que vão além do processo educacional e do lazer. Todos os participantes mantêm uma relação próxima com o ambiente do trabalho, sendo que em algumas trajetórias essa aproximação surge de forma mais enfática nos casos de Vanda, Daniel, Cíntia, Amanda, Sara e Jonas.

É importante ressaltar que apesar das dificuldades já citadas para agendamento das entrevistas e das inúmeras obrigações dos sujeitos participantes que vão muito além da condição de estudantes, todos demonstraram interesse em participar da entrevista, abdicando de horas preciosas de seu descanso Esse interesse foi explicado de diversas formas pelos participantes e encontramos indicações mais concretas nas falas de Alan, Cíntia, Amanda, Vanda, Jonas, Daniel, Cássio e André.

Para Cássio a participação na pesquisa surgiu como uma forma de aquisição de experiência, já que ele compreendeu a proposta como uma oportunidade de falar um pouco de si, estabelecendo uma aproximação com as entrevistas realizadas por jornais e revistas. Nesse mesmo entendimento de possibilidade de ser ouvido, Alan, Cíntia e Amanda ressaltaram que a experiência foi importante e satisfatória uma vez que tiveram a oportunidade de falar e de serem ouvidos sobre suas experiências e o que eles pensam sobre fatores diversos. Na fala de Amanda essa satisfação fica evidente:

Achei legal uma pessoa querer me ouvir, me ajudou né?... Tinha pergunta que eu nunca parei para pensar, aí hoje eu parei - 'nossa, que legal, podia ter pensado nisso'. Ah, eu me abri, me soltei bastante, acho que foi bem legal. Porque é muito bom quando alguém quer te ouvir. 
Por sua vez, Vanda, Jonas, Daniel e André, aceitaram participar da entrevista pela oportunidade de ajudar outra pessoa, no caso a pesquisadora. Daniel inclusive disse ter aceitado por já ter participado de outra pesquisa quando criança e que julgou "não custar nada ajudar”. Essa vontade de ajudar a pesquisadora, ressaltada por Vanda, Jonas, Daniel e André, demonstra também a existência de uma percepção e sensibilidade sobre as necessidades daqueles que os rodeiam e que, nesse caso, remetem a uma experiência específica dos estudantes do Instituto que por precisarem desenvolver um trabalho de conclusão de curso, conhecem, ainda que de forma pontual, o funcionamento de uma pesquisa acadêmica.

Cabe considerar ainda que o fato de a maioria das entrevistas ter sido realizada em espaço público, embora em condições que asseguraram privacidade, levanta questões metodológicas importantes, e que aqui são apresentadas de modo geral e como elemento que pode ampliar discussões sobre a prática da realização de entrevistas. 


\section{CAPÍTULO 5: FAMÍLIA E ESCOLA}

Neste capítulo serão discutidos e analisados aspectos referentes aos vínculos dos alunos com as famílias, com os pares, bem como os vínculos com diferentes denominações religiosas. Essas áreas se entrelaçam e serão analisadas em suas peculiaridades e nas articulações que mantêm entre si.

Antes de iniciar, esclarece-se que os vínculos dos alunos com a religião surgiram durante as entrevistas como dado imprevisto, pois no roteiro de entrevistas não havia nenhuma pergunta voltada para esse tema. Nesse caso, pode-se aplicar à presença da religião na experiência de seis adolescentes a mesma reflexão, fundada nas análises de DaMatta (1981) e Fonseca (1999), e apresentada no item Metodologia para se discutir a questão relacionada à cor dos sujeitos, e que se reporta ao surgimento de fatos inesperados, mas que podem ser incorporados para se ampliar e aprofundar a análise.

Os dados que surgiram nas entrevistas, mesmo sem perguntas diretas sobre o tema, mostraram que a religião ocupa parte importante nas vivências dos adolescentes e que além da dimensão propriamente espiritual e normativa, isto é, de oferecer orientações para a vida social, a filiação a determinadas crenças e a participação em cultos assegura a criação de uma rede de sociabilidade que tem relação com o processo de escolarização. Por isso, os dados sobre filiação religiosa, em sua relação com a escolarização, foram agregados ao texto e serão discutidos no decorrer da exposição.

\subsection{As famílias dos adolescentes}

Escola e família configuram-se como duas grandes instituições socializadoras, cada uma a seu modo e dentro de suas possibilidades e limitações influenciam o desenvolvimento escolar e pessoal dos sujeitos.

Inicialmente, descreve-se os grupos familiares aos quais esses estudantes pertencem e que apresentam algumas características comuns. Todos os pais têm entre 36 e 59 anos e contam com rendimentos de aproximadamente 2 a 6 salários mínimos. Nesse montante, não estão incluídos os rendimentos dos filhos, pois quando estes trabalham, como é o caso de Jonas, Sara, Vanda, Cíntia, Cássio e da irmã de Amanda, seus ganhos são usados por eles mesmos, o que acaba por reduzir os gastos dos pais, já que estes não precisam arcar com despesas ligadas ao consumo dos filhos. A exceção é Daniel que trabalha meio período 
ganhando $\mathrm{R} \$ 20,00$ por dia e que utiliza o valor que recebe para ajudar a mãe a sustentar a casa, guardando apenas uma parte para seu próprio uso.

O número de integrantes de cada família varia entre três e cinco membros. Dessas famílias uma é matrifocal, duas são recompostas e sete são nucleares. Dentre as ocupações dos pais há três pedreiros, um mandrilhador, um empreiteiro de obras, um motorista, dois pintores, um encarregado industrial e um eletricista. Duas mães dedicam-se às atividades do lar, uma é cuidadora dos pais de forma remunerada, duas são diaristas, uma é auxiliar de limpeza, outra é vendedora e representante comercial, uma é secretária, uma é proprietária de cantina de escola e uma é auxiliar contábil.

Apenas a família de Daniel conta com ajuda de recursos financeiros oriundos de transferências governamentais, como o Programa Bolsa Família uma vez que a faixa de rendimento familiar está dentro dos limites impostos pelo programa. Além desse benefício a família está entrando com um processo para ter direito ao Auxílio Reclusão, agora que o pai, que era o principal provedor da renda familiar, está detido por tráfico de drogas.

A escolarização dos pais, conforme quadro abaixo, é um aspecto a ser ressaltado, uma vez que entre os entrevistados não existem pais não alfabetizados, e os níveis de escolarização podem ser agrupados em quatro subconjuntos: ensino fundamental incompleto, ensino fundamental completo, ensino médio incompleto e ensino médio completo, sendo que neste último caso alguns pais ainda têm ensino técnico completo. A única exceção é sobre a escolarização dos pais de Daniel, já que este declarou não ter informações sobre isso. Desse modo nove pais e mães têm entre oito e doze anos de escolaridade, enquanto três pais e duas mães apresentam o ensino fundamental incompleto.

\begin{tabular}{|c|c|c|}
\hline Sujeito & Pai & Mãe \\
\hline Daisy & Ensino fundamental incompleto & Ensino fundamental completo \\
\hline André & Ensino médio completo & Ensino fundamental completo \\
\hline Amanda & Ensino médio incompleto & Ensino técnico \\
\hline Daniel & Não soube responder & Não soube responder \\
\hline Jonas & Ensino fundamental completo & Ensino fundamental completo \\
\hline Sara & Ensino fundamental completo & Ensino médio completo \\
\hline Vanda & Ensino fundamental incompleto & Ensino fundamental incompleto \\
\hline Cíntia & Ensino fundamental incompleto & Ensino fundamental incompleto \\
\hline Cássio & Ensino técnico & Ensino médio completo \\
\hline Alan & Ensino médio incompleto & Ensino médio incompleto \\
\hline
\end{tabular}

QUADRO 3 - Escolarização dos pais e das mães dos sujeitos 
Essas famílias integram as camadas populares com rendimentos na faixa salarial descrita acima, e se não dependem dos ganhos dos filhos para se manterem, também não dispõem de recursos financeiros para oferecer-lhes acesso a bens de consumo tão desejados por adolescentes e que eles adquirem com seus recursos, sejam provenientes do trabalho ou de estágios. De qualquer modo, essas famílias, em maior ou menor grau e de formas diferentes, empenham-se em direcionar os filhos para a conclusão do ensino médio e também têm aspiração de que eles tenham acesso à educação superior, como são os casos de Daisy, André, Amanda, Sara, Vanda, Cíntia, Cássio e Alan. Essa aspiração está associada à posição ocupacional dos pais e a seus rendimentos e eles desejam que os filhos possam ascender socialmente através da escolarização, como as pesquisas de Portes (2000), Viana (2005) e Zago (2006) têm demonstrado.

A relação entre escola e família permeia em maior ou menor intensidade a fala de todos os entrevistados, inclusive ressaltando a mãe como a mais presente nas questões do mundo escolar. A participação dos pais, mais notadamente da mãe, no acompanhamento de tarefas escolares e reuniões se deu com mais intensidade na infância dos estudantes, tendo perdido espaço a partir do momento em que se tornaram adolescentes quando, segundo os pais de alguns deles, já deveriam possuir senso de responsabilidade e disciplina próprios, não necessitando mais da constante cobrança parental. Isso não significa, porém, que esses pais não conversem ou perguntem aos filhos sobre o que acontece na escola e o que eles aprendem.

As condições objetivas de vida dessas famílias, o espaço social que elas ocupam, uma cidade do interior, as ocupações profissionais dos pais e sua escolarização devem ser consideradas de modo que se consiga problematizar as representações que os sujeitos possuem sobre a importância do pai e da mãe na escolarização e no trabalho.

Conforme Watarai (2006, p.14) analisa as relações de famílias de camadas populares:

[...] no plano das representações, o desempenho de trabalho remunerado é predominantemente considerado tarefa de adultos do sexo masculino, sendo confiado ao marido/pai, que exerce autoridade sobre a esposa e os filhos. Em contrapartida, cabe à mulher o desempenho das tarefas domésticas, assim como o cuidado e a criação dos filhos.

Risk (2012, p.96) ressalta ainda a influencia da subjetividade dos sujeitos na construção dessas representações sobre a ação de pai e mãe: 
[...] a socialização familiar implica a incorporação de disposições tributáveis à determinada posição no espaço social, conforme a distribuição e hierarquia dos diversos capitais na estrutura social, processo que está embebido de afetividade, ou seja, de manifestações de cuidado, zelo, como também, de certa agressividade, a partir das quais os filhos podem se identificar com seus pais e constituir representações a respeito dessas figuras, não se devendo descartar a agência de outras instituições como escola, mídia, espaços socializadores, em geral, que também difundem representações acerca das figuras maternas e paternas. Imiscuída à afetividade familiar, pode-se afirmar que a sociabilidade doméstica também é constituída por representações acerca das relações de gênero, tributando-se à mulher/mãe maior proximidade com os filhos e ao homem/pai, relativo distanciamento.

Dos dez entrevistados, seis citam ter mais proximidade com a mãe do que com o pai, como Daisy, Jonas, Sara, Cíntia, Cássio e Alan. Entre os outros quatro que citaram maior proximidade com o pai estão Vanda, Daniel, Amanda e André. Nesse sentido, o gênero de cada filho não aparece como elemento importante para definição da relação de maior ou menor proximidade entre ele e pai ou mãe.

Quando interrogados sobre a importância da mãe e do pai em seu desenvolvimento escolar, Cássio, Daisy, Cíntia, Daniel, Sara, Jonas e Vanda relataram acreditar não existir diferença, mas ressaltaram que a mãe era mais participativa e rígida nos assuntos referentes à escolarização.

As explicações sobre maior proximidade com um genitor constam dos depoimentos e fundam-se no modo de relacionamento com os pais e contêm avaliações subjetivas desse relacionamento. Para Daisy a mãe lhe oferece mais liberdade para brincadeiras e conversas; Jonas credita ao maior tempo passado junto a sua mãe a forma de sua relação com ela. É a mãe que o estimula a ingressar no ensino superior e o pai, ainda que perceba a importância da escolarização, não vê necessidade da realização de um curso superior; já que o ensino técnico seria suficiente para o filho conseguir um bom emprego nas indústrias de Sertãozinho.

Cíntia e Sara, membros de famílias recompostas, explicam suas respostas na mesma lógica utilizada por Jonas porém, vão além e dizem considerar suas mães mais presentes em suas vidas. Sara ainda utiliza a expressão "porque mãe é mãe" para logo depois continuar dizendo que é por notar uma identificação de pensamentos com sua mãe, além da admiração que sente por tê-la criada sozinha por tantos anos após o divórcio dos pais.

Para Cíntia a mãe é sempre a primeira referência para dar conselhos, incentivá-la a melhorar seu desempenho escolar, ameaçando deixá-la de castigo, sem sair, caso suas notas piorem demais, e foi ela também quem deu informações sobre o ensino técnico, já que fez vários cursos profissionalizantes nas áreas de alimentos e segurança do trabalho por exemplo. Já no tocante à importância dada à escolarização de Cíntia tanto o pai quanto a mãe aparecem 
como figuras importantes. Antes da separação dos pais, o pai era o responsável por ajudá-la com exercícios de matemática, enquanto sua mãe ajudava com os de português, além de ambos olharem seus cadernos todos os dias até ela completar dez anos. Ambos também cobram da filha frequência às aulas e fornecem conselhos sobre suas escolhas acadêmicas para o futuro, sendo que sua mãe a influencia a cursar algo na área de moda e seu pai na área de engenharia civil. Ela própria, porém, está em dúvida, pois não pretende seguir carreira na área de automação ou engenharia e se vê dividida entre o ramo da moda e o da gastronomia que aprendeu a gostar em seu trabalho na cantina da mãe.

Já Cássio e Alan, explicam a proximidade com a mãe através da existência de maior liberdade e segurança que sentem em relação a ela. Alan também cita a forma mais carinhosa da mãe em cuidar dos filhos, quando comparada ao pai.

A mãe também aparece na fala de todos os participantes como uma das responsáveis por fornecer a maioria dos conselhos que recebem da família. Daisy, Cíntia e Sara citam somente a mãe como suas maiores interlocutoras, já os demais participantes apesar de mencionarem a mãe, incluem outras figuras. O pai aparece na resposta de André, Alan, Cássio, Vanda, Jonas, Daniel e Amanda.

Por ser considerada mais próxima ao ambiente escolar e aos projetos de escolarização dos filhos, a mãe acaba sendo responsabilizada pela escola diante do mau desempenho escolar dos filhos. Carvalho (2013, p. 64) demonstra que "são as mães as maiores acusadas de irresponsabilidade ou incompetência quando a escola acusa de forma ampla 'as famílias"”. Diante dessa realidade Romanelli (2013), ressalta a importância de se problematizar as relações do pai com os filhos para se ter uma análise mais ampla da atuação parental no processo de escolarização.

O pai, por outro lado, aparece ligado ao mundo do trabalho, com suas regras, seu caráter formal, associando o homem como o provedor da família. Essas características aparecem muito claramente na fala de André,

O papel [do pai] é mais brutal assim, sabe? Mais assim: você tem que trabalhar, você tem que ganhar dinheiro, você tem que sustentar... Sabe? Mais pra ensinar a viver fora de casa.

Essa diferenciação entre o pai e a mãe aparece também na importância atribuída ao mundo do trabalho e à escola. A mãe de André aparece como uma figura mais afetiva, mais sensível e mais presente no acompanhamento escolar. Ainda que atualmente já não confira mais as atividades passadas pela escola e não tenha informações para ajudá-lo com o conteúdo, ela se interessa pelo que acontece na escola conversando com ele e observando a 
execução de trabalhos feitos em casa. Ele dá o exemplo de um trabalho realizado no primeiro ano em que precisava montar um circuito e a mãe ficava por perto perguntando como ele fazia, como funcionava etc. Essa ação da mãe confirma novamente a atenção para o trabalho escolar do filho conforme Portes (2000) explicita.

Tal qual Sarti (2010) expõe, André parece colocar na figura paterna, em seu caso o único responsável pelo sustento da família, a autoridade de chefe da família, o responsável por ensinar a prole como sobreviver no mundo externo ao familiar. Nas palavras da autora:

O homem corporifica a ideia de autoridade como uma mediação da família com o mundo externo. Ele é a autoridade moral, responsável pela respeitabilidade familiar. À mulher cabe outra importante dimensão da autoridade: manter a unidade do grupo (SARTI, 2010, p. 28).

Os participantes que escolheram o pai como a figura de maior proximidade também apresentam explicações mais subjetivas, sendo que as respostas de Daniel e André se assemelham na medida em que ambos utilizam práticas e interações tipicamente masculinas como a razão para essa proximidade:

André: Ah sei lá, acho mais fácil falar as coisa para o meu pai... minha mãe fica perguntando demais, meu pai já sabe mais ou menos como é que é...

Pesquisadora: ele não fica fazendo muitas perguntas?

André: Não! Ele só f(interrompe) orienta e "deixa rodá".

Daniel: Ah sei lá, a gente brincava junto, essas coisas, a gente tinha muita "brincadeira de mão" [...] meu pai é homem, eu sou homem aí acaba tendo um vínculo... você se, como é que fala? Se espelha mais né?

Entre as entrevistadas a proximidade com o pai se dá pela comparação com a mãe. A mãe de Amanda teve depressão pós-parto nas duas gestações, o que promoveu uma aproximação das filhas com o pai desde pequenas, relação que se manteve ao longo de suas vidas. Essa diferença de relacionamento fica mais visível no seguinte trecho da entrevista com a participante:

Pesquisadora: Como é seu relacionamento com sua mãe?

Amanda: Hum, ah! Nor(interrompe), não sei explicar, eu e minha mãe a gen(interrompe), assim... eu amo minha mãe, minha mãe me ama, mas ela na dela e eu na minha entendeu? E a gente não conversa muito...

Pesquisadora: E com seu pai?]

Amanda: Meu pai, eu amo meu pai! A gente conversa muito, conversa bastante... mas a minha mãe ela nã(interrompe), ela assim... ela é boazinha e tudo, mas... não comigo, com as outras pessoas sabe? Às vezes eu vou falar alguma coisa e ela sempre nunca tem tempo pra conversar... é sempre assim. 
Ainda assim, Amanda considera a figura da mãe, e também do pai, como fundamentais para a criação dos filhos, colocando, inclusive, que esse deve ser um trabalho em conjunto, pois ela acredita que se os projetos dos pais para os filhos não coincidirem, o filho fica confuso, sem saber quem seguir. E apesar de expressar maior intimidade com o pai, ao responder sobre a importância da mãe na criação e desenvolvimento escolar dos filhos, Amanda responde que é a comunicação, a instrução sobre o que o filho não sabe ainda, ao passo que quando responde a mesma pergunta sobre o pai ela responde primeiro que o mais importante é o aporte financeiro que ele fornece para a execução do projeto educacional, e só depois ela pondera que o papel dos dois é o mesmo, o de instrução, de criação de um projeto para o filho.

Já com Vanda a proximidade com o pai ocorre por uma maior identificação de "gênios", uma vez que ele que é descrito por ela como alguém mais calmo, mais parecido com ela própria, enquanto a mãe é descrita como sendo mais "explosiva".

Essa divisão de funções entre o pai e a mãe estabelece uma diferenciação marcada pelas relações de gênero que vão ao encontro das interpretações de autores como Martuccelli (2007) para quem a origem social e a escolaridade da mãe são fatores importantes na análise do sucesso escolar, já que ela é a responsável pelo acompanhamento escolar dos filhos e poderia exercer uma influencia dominante em suas trajetórias. Outros autores que fornecem informações importantes para a reflexão sobre o papel do pai e da mãe são Romanelli (2013), Carvalho (2013), Watarai (2006) e Risk (2012).

Além dos pais, outros personagens são importantes no cotidiano desses adolescentes e em sua escolarização. Vanda inclui a irmã, além da parentela, isto é, os parentes do lado materno e paterno, como também ocorre com Jonas, Amanda e Cássio.

Os pais de Cássio ainda que não consigam ajudar o filho nas dúvidas, buscam auxílio com parentes e conhecidos que estejam mais capacitados para sanar as dúvidas escolares do filho. Na trajetória de Cássio a participação de uma rede de parentes é muito forte e ele confere grande importância aos tios e primos em sua educação. Esse relacionamento em famílias de camadas populares é analisado por Sarti (2010, p.31) para quem essas famílias "constituindo-se em rede, com ramificações que envolvem o parentesco como um todo, configura uma trama de obrigações morais que enreda seus membros".

\subsection{As relações dos adolescentes com a família e a escola de ensino fundamental}


Para melhor se apreender a atuação da família para o ingresso no Instituto inicialmente procede-se à análise da relação que esses adolescentes tiveram com a escola durante o ensino fundamental.

A escola exerce o papel de detentora dos vereditos acerca da capacidade e sucesso escolar dos alunos através de suas notas e de seu desempenho na escola, como também é a detentora das informações necessárias para a transformação das trajetórias dos entrevistados.

Os vereditos escolares estão presentes nas trajetórias de todos os sujeitos, que com exceção de André, sempre foram considerados bons alunos, sem repetências ou grandes dificuldades, vereditos esses que serviram como incentivo para o exame de seleção do Instituto.

Os casos de Daisy, Jonas, Daniel, Amanda e Sara podem ser exemplares A trajetória escolar de Daisy se desenvolveu em escola pública sem repetências ou grandes dificuldades, sendo, mesmo em comparação com suas irmãs sempre "a mais esforçada", sempre teve notas boas e foi a única a ter interesse em estudar em outra cidade. Seu maior interesse pelos estudos seria percebido até pelas outras pessoas e por isso seus pais sempre acompanharam e valorizaram sua escolarização de perto, sendo que sua mãe ainda cobrava que ela fizesse as lições passadas pelos professores.

Novamente aqui é possível perceber a força dos veredictos escolares, da ideia do "bom aluno" que recebe investimento parental. O apoio e incentivo dos pais pode ser notado de modo mais concreto quando Daisy diz que eles compravam materiais para a escola sempre que preciso e que quando se deparou com problemas na disciplina de inglês no início do terceiro ano seu pai pagou um curso de férias impedindo sua reprovação.

E além do curso integrado Daisy também cursou informática com sua irmã mais velha em uma escola na própria cidade de origem. Na fala de Daisy ela cita que sua irmã mais velha eventualmente ajuda-a nas atividades escolares. A comparação de desempenho e interesse escolar é mais visível entre Daisy e a irmã caçula, que é descrita como desinteressada, com problemas de comportamento, já tendo brigado no ambiente escolar e que apesar de ainda estar no início do ensino médio já tem vontade de parar de estudar.

A escolha de Daisy pelo ensino técnico integrado está ligada à influência de uma professora de português do ensino fundamental, responsável por informá-la sobre a escola ao final do oitavo ano e continuar incentivando-a ao longo do nono ano. Foi, então, pela insistência da professora que dizia a ela que tinha capacidade, "nível" para uma escola melhor, pela ajuda de outros professores que passaram a emprestar livros e pelo contato com uma antiga colega de escola que Daisy escolheu o Instituto. 
Daniel, por sua vez, nunca teve reprovações e seu bom desempenho e comportamento podem ser explicados pela influência da mãe, que desde criança o instruía a utilizar o espaço escolar para estudo e aprendizagem e não para brincadeiras sendo que ele próprio cita a internalização dessas normas como a causa de seu bom desempenho.

A trajetória escolar de Jonas é considerada boa, sem repetências ou dificuldades e a fiscalização das tarefas escolares pela mãe não foi necessária, ainda que ela o cobrasse quando percebia que ele não fazia atividades em casa há algum tempo. Jonas conta que quando tinha a idade de seus irmãos a mãe lhe fazia recomendações para ser um bom aluno, coisa que atualmente ela faz com os irmãos. A única exceção em seu desempenho escolar foi quando morou em outra cidade e participou do grupo dos "bagunceiros". Sua mudança de município ocorreu a partir da vontade de seus pais de irem para uma cidade menor e mais tranquila e com isso passaram em torno de dois anos em outra cidade da região administrativa de Ribeirão Preto.

A fala de Jonas sobre o período em que morou em outro município permite compreender sua fase de bagunceiro como um artifício para se adaptar ao novo grupo que o chamava de "novato", o que ele define como um "tipo de bullying". Para conviver com as pressões dos colegas, ingressou na "turma do fundão" e se tornou um "bagunceiro". Uma vez de volta à Sertãozinho relata que deixou de fazer parte do grupo dos "bagunceiros" e não apresentou dificuldades no desempenho escolar até seu ingresso no Instituto quando enfrentou problemas nas disciplinas técnicas, mas conseguiu recuperar-se nos finais dos anos letivos.

Sara comenta que sua mãe costumava acompanhar seus afazeres escolares até o primeiro ano do ensino médio, inclusive para que ela refizesse as atividades que continham algum comentário negativo dos professores e também ia à escola para tomar conhecimento de seu desempenho e comportamento durante as aulas. Mas nos últimos três anos ela vem conferindo mais autonomia à filha tendo praticamente deixado de lado essas práticas. Quanto ao pai, Sara relata que apesar de ter importância tão grande quanto à da mãe, seu pai não exerceu influencia tão profunda em sua escolarização.

Amanda também descreve ter tido boa trajetória escolar e teve o apoio dos pais, através de pesquisa sobre o processo seletivo para o Instituto e a compra de material para estudo. Ela contou principalmente com o apoio da mãe e também de professores do ensino fundamental que a incentivavam a prestar o processo de seleção para o Instituto dado seu bom desempenho escolar. O mesmo aconteceu com Cássio e Vanda que tiveram importante participação dos professores no seu processo de escolha pelo Instituto, conforme pode ser notado nos seguintes trechos de suas entrevistas: 
Pesquisadora: Como foi sua escolha pelo ensino técnico? Quem participou e como foi?

Vanda: Por incentivo dos professores, [...] a gente veio com a escola, para conhecer e tal... ai eu vi que eu queria isso mesmo.

P.: Em que momento o ensino técnico integrado ao ensino médio entrou como opção para você?

Vanda: Porque eu fui medalhista da Olimpíada de Matemática aí eu tinha um professor que me incentivava pra caramba: "vai, tenta tal, que lá o ensino é desse jeito" eu nem conhecia a escola nem nada. [...] no começo eu nem sabia, eu nem queria continuar na área, agora eu já penso em continuar nessa área de automação mesmo... Ah! Eu acho isso, eu acho que me ajudou a escolher mesmo o caminho que eu vou querer seguir.

Nas falas de Daisy, Amanda, Daniel, Sara, Cíntia, Cássio e Alan, é possível notar o desejo de irem para uma escola particular no ensino médio, o que na maioria dos casos não seria possível pelas dificuldades financeiras das famílias.

A mãe de Cíntia chegava a ameaçá-la enviar para uma escola estadual no ensino médio para que ela não tivesse quedas de rendimento escolar no ensino fundamental. Já os demais alunos descrevem de forma preocupada sua trajetória se tivessem ido para estabelecimentos da rede estadual, conforme pode ser visto nas duas falas a seguir:

Daniel: Bem melhor o ensino lá [no Instituto], bem melhor, lá [escola em que estudava] é escola estadual né, escola estadual infelizmente no Brasil o ensino é precário.

Alan: Escola estadual, o ensino é bem... sabe? A escola que eu estudava... tinha umas partes que até... Meio que deterioradas... O ensino estadual é bem... Até esquecido pelo estado eu acho, tem umas escolas que estão em situações ruins.

Na maioria dos casos, com exceção de André que cursou o ensino fundamental em instituição particular, a escola pública, mais notadamente a da rede estadual, surge como coprotagonista, ao lado da família, e, às vezes, como antagonista de acordo com algumas avaliações dos dez sujeitos ouvidos.

Considerar a escola de ensino fundamental como co-protagonista significa que foi através das relações criadas nesse período que Daisy, Amanda, Daniel, Jonas, Sara, Vanda, Cíntia e Cássio souberam da possibilidade de cursarem o ensino médio no Instituto. Quando perguntados como foi o processo de escolha pelo ensino médio técnico e também em que momento ele surgiu como opção os entrevistados citam figuras de seu convívio escolar, sejam eles professores, funcionários da escola ou amigos do ensino fundamental, conforme pode ser notado nos trechos das entrevistas com os sujeitos: 
Pesquisadora: Em que momento o ensino técnico integrado ao ensino médio entrou como opção para você?

Daisy: Foi no momento que a minha professora me falou [...] partiu dela [...] nem passava pela minha cabeça estudar numa federal, só que aí a professora falou, aí passaram as férias, quando voltou ela perguntou de novo, ela: "não Daisy, faz lá, pelo menos tenta né", [...] Aí como tinha uma menina lá da escola que já estudava lá, que tinha estudado comigo lá no [escola de ensino fundamental] e tava nessa Federal aí eu procurei saber com ela, [...] Ai meu professor também de ciências me incentivou, meu professor de matemática... Me ajudaram, me deram livros sabe, para eu estudar.

Pesquisadora: Como você ficou sabendo do Instituto?

Cássio: Na oitava série algumas professoras comentaram da escola aqui, falaram que era uma escola muito boa por ser um instituto federal, que o ensino é muito bom e eu sempre tive essa vontade de crescer, nunca quis ficar no mesmo lugar, então eu falei: "não, legal, eu quero conhecer essa escola, eu quero saber como é lá mesmo" e quando teve a feira de ciência e tecnologia aqui a escola trouxe os alunos pra fazer visitação e eu fiquei encantado com o que o pessoal fazia aqui , tanto química quanto automação, eu achei muito legal os projetos, ai eu falei: "não, eu tenho que prestar essa prova, eu tenho que ir pra essa escola de qualquer jeito".

A avaliação negativa das escolas públicas se estende à opinião de Daisy após seu ingresso no Instituto, que oferece formação considerada boa por fornecer conhecimentos aprofundados em relação às escolas estaduais. Para exemplificar ela cita que em seu primeiro ano estava aprendendo conteúdos que sua irmã estava vendo pela primeira vez no terceiro ano do ensino médio da rede pública. Por esse motivo ela diz que se sente mais preparada para prestar o vestibular.

Todavia, deve-se fazer uma ressalva quanto a essa avaliação dos alunos. Professores mais qualificados, isto é, com títulos de pós-graduação como ocorre com alguns docentes do Instituto, não têm necessariamente melhor atuação na forma de transmissão de conhecimento e ainda nas relações que mantêm com os alunos. É importante ressaltar que o corpo docente do Instituto no Campus de Sertãozinho conta com 53 docentes, sendo que deste total, 42 tem curso de pós-graduação e 28 são mestres e 14 doutores, ministrando aulas tanto no ensino médio quanto superior (INSTITUTO FEDERAL SÃO PAULO).

Por outro lado, considerar a escola como antagonista reporta-se ao fato de que a percepção dos alunos era na direção contrária à escola estadual, vista por eles como fraca, precária, perigosa, inclusive pelo contato constante com o universo das drogas, que eles nadavam, como se depreende de algumas falas. Daisy, por exemplo, compara a realidade cotidiana do Instituto com a que conheceu nas escolas públicas de ensino fundamental e na vivência atual de sua irmã. Segundo ela é comum ocorrerem brigas e desrespeito entre os 
alunos e entre alunos e professores na rede estadual, o que não acontece no Instituto, que conforme ela relata conta com profissionais melhor qualificados.

Nesse sentido, é oportuno incluir a análise de Watarai e Romanelli (2009, p. 226), para quem “o espaço da escola é considerado pelos adolescentes como espécie de proteção social”, contribuindo para mantê-los afastados de convivências com pessoas que poderiam exercer influência negativa sobre eles.

Quanto à convivência como drogas, Alan e Cássio relatam que tiveram contato com usuários de drogas no ensino fundamental em escola da rede estadual e queriam fazer o ensino médio em uma escola de melhor qualidade e para se afastarem dessas influencias consideradas negativas por eles.

Alan relata que convivia diariamente com o cheiro dos entorpecentes utilizados por pessoas do lado externo de sua escola de ensino fundamental. Cássio viveu experiência mais próxima com usuários de drogas. Aos 11 anos, no sexto ano do ensino fundamental, ofereceram-lhe droga três vezes no banheiro da escola e após a terceira ocorrência ele pediu aos pais que o transferissem, que ele não queria mais permanecer naquela instituição. Os pais então acataram seu pedido e o transferiram para outra escola, também pública, mas onde esses episódios não voltaram a acontecer.

É temerário endossar a opinião de alguns entrevistados que consideram que as escolas da rede pública, estadual ou não, sejam locais onde drogas circulam livremente. Embora isso ocorra em diversos estabelecimentos públicos, o tráfico de drogas está bastante presente em escolas particulares, mesmo naquelas que atendem uma clientela proveniente de famílias com ganhos financeiros e capital cultural elevados. E ainda mais, escolas públicas não são frequentadas apenas por alunos usuários de drogas ou cuja conduta seria perniciosa para aqueles que desejam estudar seriamente. Novamente cabe lembrar que escolas particulares também contam com alunos cujas condutas também são perniciosas e negativas.

O que pode ser apreendido como geral e igualmente pertinente nas falas dos estudantes é que eles têm percepção comparativa bastante clara acerca das deficiências educacionais das escolas públicas que eles conhecem, seja por terem estudado nelas seja por informações de amigos, parentes ou de outras pessoas. Mas nesse caso, também é necessário cautela para não se imputar às escolas públicas, como um todo, o rótulo de que elas são precárias, deficientes e que oferecem ensino de má qualidade.

O bom desempenho desses adolescentes no ensino fundamental, portanto, remete ao explicitado por Bourdieu (1997) em relação à força que os veredictos escolares possuem no investimento ou no não investimento das famílias na trajetória escolar de seus filhos. 
As falas dos participantes, portanto, podem ser analisadas para mostrar que a escola de ensino fundamental foi importante para orientar os adolescentes para investirem no projeto de formação escolar e profissional através de ingresso no Instituto.

Contudo, as orientações e estímulos dos professores, que em alguns casos forneciam material para estudo e para o processo seletivo, precisam ser entendidas e articuladas com a postura de pais e mães que, embora atuando de formas distintas em relação aos filhos, endossaram os estímulos para que eles não cursassem escolas públicas estaduais, mas que procurassem aprovação no Instituto.

E é preciso levar em conta que os entrevistados também contaram com outras fontes de informação sobre o Instituto, originárias de contatos com amigos e parentes. Ademais, não basta dispor de informações para se fazer determinada escolha. Ela depende dos interesses específicos dos sujeitos e esses interesses e suas aspirações estão subordinadas ao conhecimento que eles vão acumulando no decorrer de suas trajetórias escolares e pessoais e que, como foi analisado acima, esses alunos incorporaram nessas trajetórias e para que fizessem a opção por um estabelecimento de ensino.

Nesse processo de negociação entre pais e filhos não só estes ampliaram suas experiências e conhecimento sobre o sistema de ensino, como também os genitores adquiriram informações e ambos, pais e filhos, puderam redefinir suas posições sobre as oportunidades e dificuldades envolvidas no processo de escolarização.

Desse modo, o endosso parental e os vários tipos de suporte que os pais ofereceram aos filhos tornaram viável que estes construíssem sua opção pelo ensino no Instituto como será analisado a seguir. Cabe ainda considerar que os dados coletados indicam que os pais apoiaram e estimularam igualmente filhos e filhas durante o ensino fundamental, sem privilegiar os homens em detrimento das mulheres.

\subsection{As famílias e o ingresso no Instituto}

A análise das falas dos sujeitos indica que a família aparece como uma rede de apoio, uma vez que os pais incentivaram os filhos a cursarem o ensino médio e também os estimulam a ingressar no ensino superior. Em pesquisa sobre o ingresso de estudantes de camadas populares em cursos de alta seletividade em um campus da USP, Piotto (2007) utilizou o termo rede de apoio para se referir ao conjunto de elementos reunidos pela família e que possibilitam aos filhos ultrapassarem limites e dificuldades econômicas no sistema de ensino. 
Embora os pais não tivessem um projeto claro e definido para a escolarização dos filhos a família atuou de "forma periférica ao estritamente escolar" (Viana, 2011, p. 54). Essa rede de apoio atuou além do "estritamente escolar" não só quando endossaram e apoiaram a escolha dos filhos para ingressarem no Instituto, mas no suporte financeiro que ofereceram de diferentes formas, seja na compra de apostilas preparatórias para o exame de seleção no Instituto, seja no pagamento das taxas de inscrição ou ainda no fato de não solicitarem aos filhos que contribuíssem para o orçamento doméstico, assegurando a eles a possibilidade de maior dedicação aos estudos.

Certamente, alguns filhos trabalham ou recebem remuneração por estágios, mas o valor recebido não é utilizado para manutenção da família. Ao contrário, são os pais que mantêm os filhos, oferecendo moradia, alimentação e outros itens de consumo dos filhos. Essa relação estabelecida entre pais e filhos aparece nos depoimentos de Sara, Daniel, Vanda, Cíntia e Jonas que trabalham e de Cássio e Amanda quando exerceram atividades remuneradas. Daniel é a única exceção e parte de seu salário é utilizado na composição do orçamento doméstico.

O apoio familiar é percebido quando os alunos citam que apesar de seus pais não saberem o que era automação industrial ou não conseguirem ajudá-los a estudar para as provas, sentem orgulho dos filhos por estudarem no Instituto, se interessam pelo que eles aprendem, perguntando como funcionam os equipamentos, o que pensam dos professores, e buscam formas de ajudá-los.

A ajuda dos pais expressa-se no apoio financeiro quanto a despesas necessárias anteriores ao ingresso no Instituto e inclui o pagamento da taxa de inscrição. Nesse caso, apenas Amanda conseguiu isenção, enquanto os outros entrevistados efetuaram seu pagamento, não sem esforço dos pais. É importante ressaltar que o pai de Daisy usava o pagamento da taxa, cujo valor era alto quando comparado com seu rendimento mensal, como forma de estimulá-la a estudar para passar no processo seletivo.

O suporte financeiro também é praticado de outras formas. A mãe de Amanda comprava apostilas para ela estudar para o processo seletivo, a mãe de André adquirira os materiais necessários para os trabalhos do Instituto, o pai de Daisy pagou curso intensivo de inglês para que ela não fosse reprovada e os pais de Sara e Jonas custearam e incentivaram seus cursos externos ao Instituto como forma de expandir seus currículos e capacitação.

Apesar das dificuldades financeiras familiares todos os entrevistados enfatizam a importância do apoio dos pais e a satisfação que expressam pela escolha do ensino técnico, o que pode ser notado principalmente nas falas de alguns alunos, como na de Jonas: 
Sempre que eles [os pais] encontram alguém conhecido eles falam com orgulho assim, tal - 'o Jonas estuda lá no Instituto Federal; é uma boa escola e vai sair com o diploma de técnico’.

Outra modalidade de ajuda não é financeira, mas busca oferecer amparo aos filhos, como fizeram os pais de Cássio quando pediram ajuda a familiares e conhecidos para auxiliálo nas dúvidas que ele tinha sobre o mercado de trabalho ou nas disciplinas da escola e também quando os pais de Alan buscam adiar seu ingresso no mercado de trabalho para que ele possa se dedicar somente aos estudos.

Mas a atuação dos pais na promoção de escolarização para os filhos ocorre ainda de outra forma, mediante o incentivo e pagamento de cursos extracurriculares. É o que ocorre com Jonas, cuja mãe o estimula a realizar outros cursos profissionalizantes como de autocad 2D, cujo objetivo é a formação de designer gráfico e digital em áreas de engenharia e arquitetura e que ele realizou em outra instituição de ensino.

Assim como Jonas, Sara realiza outros cursos extracurriculares por influencia de sua mãe que a estimula e arca com os custos de vários cursos profissionalizantes como o de inglês, um de técnico administrativo, de canto, violoncelo, informática, técnico em voltagem e manutenção, Windows 7 e web desing. Esses variados cursos feitos por Sara contribuem para que ela seja a pessoa "mais estudada" da família.

Essas ações parentais, apesar de não seguirem a mesma lógica presente nas camadas médias, que por sua própria posição social possuem maiores conhecimentos sobre o funcionamento dos estabelecimentos escolares e seus processos seletivos, demonstram o interesse dos pais na escolarização dos filhos.

Nos casos de André e Cássio, a participação dos pais aparece de forma mais direta, uma vez que eles são os responsáveis pelas escolhas do futuro escolar dos filhos. A mãe de André escolheu o Instituto e o pai de Cássio extrapolou a escolha de seu filho pela escola e acabou por determinar o curso em que ele seria matriculado. As formas de incorporação ou negociação das orientações parentais são variáveis e os casos de Daniel e Cássio podem ser elencados como exemplificadores de dois extremos.

Os conflitos entre as orientações parentais e seus interesses podem ser percebidos já no processo de escolha pelo curso de automação industrial decidido pelo pai à revelia da vontade do filho que desejava cursar química. A ação de seu pai pode ser relacionada por ele trabalhar na área de eletrônica e conhecer profissionais da área de automação, julgando, portanto, que esse curso seria melhor para Cássio do que o de química.

Ao relatar sua escolha pelo curso Cássio deixa clara a imposição do pai e sua reação: 
Cássio: A minha escolha na verdade, foi feita basicamente pelo meu pai, porque eu queria vir pra essa escola, eu queria o ensino médio integrado ao técnico porque dá uma oportunidade melhor pra gente, dá, a gente sai com emprego já... Mas eu queria me inscrever pra química, técnico em química, aí meu pai, o sonho dele sempre foi que eu fizesse automação industrial, mesmo ele não sabendo muito o que era essa área ele sempre quis que eu fizesse automação industrial, então ele veio fazer minha inscrição e disse "olha, só tinha vaga pra automação industrial", como eu não sabia como funcionava a inscrição, eu vim, fiz a prova, acabei passando, fiquei muito feliz quando eu passei e no meio do primeiro ano eu descobri que antes das aulas começarem eu poderia ter mudado de curso e eu não sabia disso então... Eu fiquei meio chateado na verdade no começo porque eu nunca gostei muito dessa área [...].

Pesquisadora: Então a escola você já queria, seu pai te ajudou a escolher o curso? [...]

C: Ajudou? Me empurrou pro curso na verdade.

Apesar de ter se mantido no curso de automação, "já que eu comecei eu termino o que eu comecei, eu não gosto de deixar nada pela metade" Cássio pretende abandonar a área de automação quando ingressar no ensino superior. Ele gostaria de cursar psicologia, letras e artes cênicas, completamente distintas da sua formação de técnico. E declara ainda que deseja fazer esses cursos em outras cidades, São Carlos, São Paulo e Rio de Janeiro. A escolha do curso superior, portanto, mostra-se tensa, pois seus pais gostariam que o filho continuasse na área de automação ou ao menos continuasse seus estudos em Ribeirão Preto, para não se distanciar dos pais:

Pesquisadora: Como vocês conversam sobre esses planos? Eles também falam sobre os planos que eles tem pra você?

Cássio: Ela [a mãe] fala "ah, eu gostaria que você fizesse tal coisa porque... " P: E o que seria essa tal coisa?

C: Por exemplo, continuar nessa área que eu estou, ou fazer alguma coisa mais perto assim, que ela... quando eu passei uma semana no Rio de Janeiro quando eu voltei ela quase me matou de tanto me abraçar porque ela tem aquele medo de eu ir embora e deixar ela sozinha, então ela sempre fala, meu pai também fala "ai, você vai fazer isso né, mas a gente tá assim, meio assim , a gente não gostaria, ou, a gente gostaria mas a situação não é pra isso e tal mas...

P: Mas pra eles [pais] o que pega mais é a questão da distancia?

C: Da distancia e da situação também né? Porque é complicado também porque, por exemplo, nessa área de artes cênicas, você não tem liberdade, muitos atores recebem ameaça das pessoas porque ficam obcecadas ou invejosas.

Embora relate uma relação de proximidade e confiança em relação aos pais Cássio não compartilha com eles os mesmos projetos, levantando a questão das tensões entre autonomia e heteronomia. Mesmo entre os adolescentes entrevistados que trabalham e têm seus próprios rendimentos a questão da autonomia ainda é tratada de forma muito relativa, uma vez que 
ainda dependem dos pais econômica, social e afetivamente, citando-os como seus principais conselheiros.

André cursou educação infantil em escola municipal e no fundamental frequentou duas escolas particulares diferentes. Transferiu-se de uma para outra porque a primeira tinha regras rígidas de comportamento às quais não se adaptou e a segunda teria sido também sua opção para o ensino médio. Porém sua mãe teve informações sobre o Instituto e resolveu que ele deveria estudar nessa escola.

A escolha pelo ensino técnico integrado, portanto, se deu através de uma imposição da mãe, restando a ele somente a opção pelo curso de automação industrial, escolhido em comparação com a outra possibilidade oferecida pela escola, qual seja o curso de química. Como ele não gostava de química resolveu cursar automação industrial mesmo sem saber exatamente o que e como seria o curso.

No caso de Daniel a religião mostra-se importante em sua trajetória e a mãe aparece como a figura mais presente, já que seu pai, apesar de seguir a mesma religião, acabou indo contra alguns preceitos do grupo das Testemunhas de Jeová. A maior presença da mãe, porém, não exclui a importância afetiva que seu pai exerce.

Sua relação com a mãe é descrita como boa, mas silenciosa e ele relata conversar sobre "quase tudo" com ela, enquanto com o pai, ele acredita conversar sobre "tudo". Além de ter maior proximidade afetiva com o pai, fato explicado por ele através da relação de gênero: “Ah, sei lá. Meu pai é homem, eu sou homem, aí acaba tendo um vínculo... você se, como é que fala? Se espelha mais né?".

Essa maior proximidade afetiva com o pai surge quando ele afirma que quando estava em casa, seu pai costumava brincar "de mão" com ele, isto é, encenando lutas entre eles. Daniel ainda tem mais contato com o pai, pois constantemente trabalhava com ele, que é motorista de caminhão.

De fato Daniel não rompe com o pai, mesmo após sua terceira detenção por tráfico de entorpecentes. Esse não rompimento pode ser notado quando ele afirma que mora com a mãe, a irmã e o pai, mesmo esse último estando detido há quase dois anos. E ele ainda deixa claro em diversos momentos que não concorda com as ações dele e que não escreve ou o visita há algum tempo mas esclarece que não escreve ou o visita como forma de controlar a saudade.

Todavia, o pai continua a ser figura afetivamente mais presente em sua trajetória, e que é descrito como alguém rígido, que cobrava dos filhos respeito com as outras pessoas. Por esses dados pode-se considerar a importância das interações afetivas e que são preservadas por Daniel. 
Nesse sentido, a postura de Daniel pode ser aproximada da análise de Piotto (2007) sobre a transmissão de capital cultural. A autora chama atenção para a importância das interações efetivas e afetivas que influenciam o processo de incorporação dos capitais familiares pelos sujeitos. A autora defende a ideia de que a simples existência dos capitais não é suficiente para sua incorporação, necessita-se que existam condições adequadas para que a transmissão ocorra.

A relação que Daniel mantém com as aspirações religiosas de seus pais, especialmente de sua mãe, demonstra uma profunda internalização e aceitação da herança transmitida por sua família, de modo que constrói toda sua trajetória escolar, social e profissional sem romper com o projeto inicial. Daniel é ainda o único dos participantes a afirmar de forma categórica que não possui interesse em prolongar os estudos no ensino superior devido a sua fé, conforme pode ser visto no seguinte trecho de sua entrevista:

Pesquisadora: E essa questão de faculdade [...] você nunca teve vontade? Daniel: Não.

P: E seus pais, eles falam alguma coisa sobre isso?

D: Também não... não, pelo fato do que a gente acredita né? Então a gente acredita que esse mundo não vai, tipo, muito para frente, então para quê ficar correndo atrás de dinheiro agora?

Dessa forma Daniel configurar-se-ia como "o herdeiro herdado pela herança”, segundo Bourdieu (1997, p.9),

Herdar é substituir essas disposições imanentes, perpetuar esse conatus, aceitar fazer-se instrumento dócil desse "projeto" de reprodução. [...] Os herdeiros que, aceitando herdar, portanto serem herdados pela herança, conseguem apropriar-se dela [...], escapam às antinomias da sucessão.

Já Vanda esclarece que os pais conferem grande importância a sua escolarização por não terem tido oportunidade de estudar e ela conta que em seu segundo ano no Instituto conseguiu uma boa oferta de emprego no setor administrativo de uma empresa. Por isso, pensou em abandonar o curso e se transferir para uma escola particular no período noturno, por ter mensalidade mais barata e ser fora do horário de trabalho. Seus pais a apoiaram mas avaliavam que ela estava perdendo uma grande oportunidade ao abrir mão do Instituto.

A transferência para a escola particular não pôde ser concluída e ela abandonou a proposta de emprego e continuou no Instituto, que considera oferecer uma educação de maior qualidade que a escola particular, pelo menos quando comparado ao período noturno. Apesar de dizer que tanto o pai quanto a mãe valorizam sua escolarização ela ressalta que a mãe é 
mais rígida que o pai e que ela tem o sonho de vê-la na universidade, não importando muito em qual curso.

Nesse caso, a avaliação comparativa que Vanda faz entre o Instituto e uma oportunidade de trabalho, e que também foi discutida com os pais, leva-a a optar pela permanência no Instituto. Vanda, portanto, endossa e incorpora as pretensões parentais quanto a seu futuro profissional.

O processo de transmissão de habitus e capitais depende não só de quem os transmite, no caso os pais, mas também do interesse daquele que recebe e incorpora essas orientações. Conforme Romanelli (2003) e Piotto (2007) ressaltam, é preciso que o sujeito não só entre em contato com aquilo que lhe é oferecido mas também que ele aceite a herança, tornando o projeto dos pais o seu próprio. No caso de Daniel essa aceitação se faz de forma expressiva, conforme pode ser notado na fala transcrita acima em que ele explica o desinteresse em realizar curso superior devido a uma crença que ele considera coletiva, pois diz "a gente acredita", e não "eu" ou "eles", o que poderia indicar uma cisão, ainda que inconsciente entre ele e os pais.

As aspirações parentais, porém, apesar de encontrarem lugar nas aspirações filiais não podem ser compreendidas como forças que submetem ou obrigam os filhos. Ao estudar como ocorre o sucesso escolar entre os filhos de famílias de camadas populares, Viana (2000, p. 5859) argumenta que apesar de as famílias participarem desse processo, "o sujeito - filho-aluno - desempenha um papel específico e ativo na construção do seu sucesso escolar [...] embora essa autodeterminação e esse investimento sejam produzidos no contexto da família, são seus".

Da mesma forma Romanelli (2009) esclarece que o fato de os pais terem determinado tipo de capital cultural não garante sua incorporação pelos filhos e que nem todas as famílias se empenham no processo de escolarização dos mais novos. Romanelli (2003, p. 252) também ressalta que a herança passada de pais para filhos necessita que esses últimos:

(...) estejam dispostos a herdar as orientações parentais. Trata-se, portanto, de uma relação dinâmica, cujas raízes estão dentro, e também fora, da família, e que se encontra radicada também na trajetória individual de cada filho.

As colocações dos dez participantes indicam ainda alguns pontos analisados por Fabbrini e Melucci (1992) que interpretam a adolescência como o início da capacidade do sujeito de falar sobre si mesmo, de perceber sua própria trajetória e construir percepções sobre si, o que, porém, não é feito de forma simples e isenta de introspecção. O silêncio e os não 
ditos são, segundo os autores, muito presentes na vida do adolescente uma vez que ele ainda está construindo o saber sobre si mesmo.

Esse processo de construção pode ser apreendido nas falas dos sujeitos quando eles se valem de expressões genéricas como "tudo" para se referirem aos assuntos das conversas com os pais, e que na verdade se transformam quando perguntados sobre o que seria esse "tudo", que passa a ser em cada um dos sujeitos um conjunto de assuntos específicos. Cássio, por exemplo, diz conversar sobre tudo com seus pais, mas em outro momento da entrevista explica como prefere guardar determinados temas para si mesmo, só os exteriorizando quando percebe a necessidade de ajuda, e mesmo assim alguns temas são mais comuns com o pai ou a mãe.

Essas ponderações, porém, não podem presumir a existência de uma incomunicabilidade familiar, conforme Fabbrini e Melucci (1992) nos chamam atenção, pois, ainda que de forma direcionada, os sujeitos demonstram manter diálogos com ao menos um dos familiares.

Fabbrini e Melluci (1992) compreendem a adolescência como momento em que a necessidade de mudança se choca com o medo de efetuá-la, e no qual as mudanças não são somente internas, elas modificam as relações mantidas com os outros e as coisas externas ao sujeito. Além disso, em muitas de suas falas os adolescentes revelam, mesmo que modo indireto, que muitas questões de suas trajetórias ainda não foram exploradas por eles, e pode demonstrar a adolescência como fase de construção e descoberta em que eles ainda não conseguem expressar com clareza as dúvidas e incertezas quanto ao futuro. Nesse sentido, suas representações sobre os caminhos a seguir ainda estão em processo constante de (re)construção.

É nesse sentido que apesar de ter aceitado a imposição do pai na escolha pelo curso técnico, Cássio marca, ainda que de forma sutil, que a escolha pela permanência foi sua, e se coloca agora, às vésperas da escolha pelo curso superior, contrário às indicações e aos conselhos dos pais. Nesse caso, autonomia e heteronomia, portanto se mesclam e entrem em conflito em sua trajetória e podem ser articuladas à análise de Singly (2007, p.134-135):

Em um mundo social onde o valor de referência se tornou o self, a família conserva uma utilidade: a de ajudar cada um a se construir como pessoa autônoma. $\mathrm{O}$ enunciado dessa função da família revela contradições internas: é pela mediação do outro que o indivíduo pode ser (ter a sensação de ser) ele mesmo. Os elos de independência são, ao mesmo tempo, necessários e negados. 
Cássio, portanto ao contrário dos demais participantes, apesar de compartilhar com os pais a importância dada aos estudos e ao trabalho e também à elaboração de um projeto de longevidade escolar, procura ultrapassá-los na medida em que busca se libertar da casa e das decisões referentes aos cursos que pretende realizar.

Para Cássio a oposição aos pais aparece de forma mais contundente, mas todos os demais participantes, exceto Daniel, também apresentam de forma sutil tensões, mal-estares e negociações, ainda que todos se deixem herdar. Essa herança, inclusive, pode ser caracterizada como bem sucedida nos termos definidos por Bourdieu (1997, p. 9), "a herança bem sucedida é um assassinato do pai realizado com injunção do pai, uma superação do pai”, uma vez que todos os participantes já apresentam escolarização igual ou superior à dos pais, superação essa que foi não só incentivada como garantida pelos pais - já que mesmo aqueles que trabalham, novamente com exceção de Daniel - não são os responsáveis pelo pagamento do transporte até o Instituto ou dos materiais escolares.

A herança entendida, portanto, como construção e negociação entre os sujeitos envolvidos aproxima-se do entendimento de Lahire (1997, p. 341) para quem:

Falar de 'transmissão' é principalmente, conceber a ação unilateral de um destinador para um destinatário [...] mesmo nas mais formais situações de aprendizagem, o que o adulto julga 'transmitir' nunca é exatamente aquilo que é 'recebido' pelas crianças [...] a noção de 'transmissão' não explica muito bem o trabalho de apropriação e de construção - efetuado pelo 'aprendiz' ou pelo 'herdeiro'.

Além disso, conforme Romanelli (2009), os filhos, no contato com outros grupos, como o de pares, reordenam o capital cultural que recebem da família, já que podem manter contato com indivíduos de outros segmentos sociais, nesse sentido, a escola é também espaço de sociabilidade que pode permitir esses encontros ou aumentar o fosso entre eles.

Conforme já discutido anteriormente, porém, é preciso que não se impute à família um poder exacerbado de determinar as trajetórias individuais, ou conforme Romanelli (2003, p. 251) chama a atenção: “torna-se claro que a família não é um grupo todo poderoso que, como sujeito, coletivo, teria o condão de impor integralmente seu projeto de escolarização aos filhos". Mas, se a família não tem tal poder, porque André e Cássio acatam as imposições de sua mãe e seu pai, respectivamente?

Ao longo das falas dos dois sujeitos algumas pistas podem ser colhidas para explicar a obediência às orientações, ou imposições, paternas. No caso de Cássio, conforme já citado, a obediência ocorre por ele só descobrir a imposição paterna após o prazo que teria para solicitar a transferência de curso dentro do Instituto, e ele, não gostando de abandonar as 
coisas pela metade, opta por continuar no curso, tentando para isso estabelecer conexões entre o curso de automação e outras atividades que ele gosta, como as aulas de teatro, em que ele percebe a ajuda da automação no desenvolvimento de sua capacidade de raciocínio lógico e pensamento rápido, importantes para uma boa ocupação do palco e improvisação.

André, por sua vez, aponta como sua vontade e única outra opção de escola, além do Instituto, a escola particular em que cursou o ensino fundamental. Mas André dependia dos pais para o custeio do ensino médio e esse fator limitador não assegurou condições suficientes de negociação ou recusa. Assim como Cássio, porém, André aponta a permanência no curso como escolha sua, tendo desenvolvido interesse e gosto pelo curso de automação industrial, citando as disciplinas técnicas como suas preferidas na escola, além de dizer durante a entrevista que "hoje eu gosto [não foi uma escolha sua mas] mas deu certo".

A família, portanto, apesar de não ser a detentora das informações sobre o Instituto colocou em ação, cada uma a seu modo, o processo que garantiu aos dez participantes da pesquisa o ingresso e a permanência de seus filhos durante os quatro anos de curso. Os pais endossaram e acataram a escolha de seus filhos pelo Instituto, apoiando-os em suas escolhas como nos casos de Vanda, Daniel, Jonas, Sara, Amanda e Alan.

Alan: minha mãe ficou sabendo da escola aqui e ela queria que eu estudasse aqui $[. .$.$] porque ela achava que o ensino era melhor, porque a escola que eu$ estudava era estadual.

Sara: os dois [pai e mãe] quando souberam que eu tinha feito a inscrição eles queriam a todo o momento que eu fosse pra lá, já não queriam mais que eu fosse pra escola particular... porque... ter um curso técnico hoje já é um diferencial.

As famílias dos entrevistados procuram oferecer a eles condições para assegurar escolarização em escola considerada de qualidade e buscam ainda oferecer-lhes condições concretas e incentivos para aprimorem sua formação. Desse modo, as famílias aparecem de forma importante e apesar de os pais não terem informações sobre o Instituto ou sobre o curso, eles foram responsáveis para garantir condições favoráveis de escolarização para os filhos.

Retoma-se aqui o que foi apontado no final do item anterior, isto é, os pais não incentivaram e estimularam apenas os filhos do sexo masculino em detrimento das filhas. Essa postura parental levanta a suposição de que os pais não investem primordialmente na escolarização dos homens, como foi prática em um passado não tão remoto, mas tendem a colocar filhos e filhas em posição de igualdade pelo menos no que diz respeito à escolarização de ambos. 
Embora tal constatação seja fruto de pesquisa realizada com um número limitado e específico de sujeitos, esse dado poderá ser ampliado em investigações sobre diferenças, ou ausência delas, na escolarização de filhos e filhas.

\subsection{Os adolescentes e suas relações com a religião e com os pares}

Outro grupo que aparece na fala de seis participantes como importante em sua escolarização e para propiciar a reunião da família e para o contato com os pares é a religião. A frequência a determinadas igrejas é importante para estabelecer relações com o grupo de pares, isto é, com amigos que partilham algo em comum entre si e que oferecem suporte e orientação para os adolescentes, inclusive no processo de escolarização.

Daniel é Testemunha de Jeová, Jonas é membro da Congregação Cristã do Brasil, Amanda é da Igreja Ágape, Cássio é católico, Sara frequenta a Igreja do Evangelho Quadrangular e Alan a Congregação Cristã do Brasil. Em todos esses casos os amigos da igreja servem como exemplo e influenciam as decisões dos adolescentes que seguem suas crenças de forma próxima e atuante.

Alan, por exemplo, ficou conhecendo os cursos do Instituto através de um amigo da Congregação Cristã do Brasil que fazia o curso de automação industrial. Seu pai, que também conhecia pessoas que trabalhavam na área de automação e que conheciam o Instituto, acreditou que a melhor opção para Alan seria cursar o ensino médio no Instituto, uma vez que seria uma escola melhor, com preparação técnica e principalmente uma formação de ensino médio superior ao que as escolas estaduais ofereciam.

Nos casos de Alan, Daniel e Jonas ficam explicitados que a igreja é um espaço de convívio que reúne toda a família, uma vez que os três citam as idas aos cultos como momento em que toda a família, pais e irmãos, estão reunidos. Alan utiliza a penúltima pergunta do roteiro de entrevista, em que se abre a possibilidade para o participante acrescentar algo que sinta necessidade, para demarcar a importância da religião em sua trajetória. Ele coloca que "meus pais, que eles estão sempre apoiados pela Igreja, pra sempre acreditar em Deus e ter fé nas coisas que você sempre conquista o que você... para você sempre ter fé e... perseverança".

A confiança que eles citam nos amigos da igreja pode ser exemplificada pelo seguinte trecho da entrevista de Sara: 
[...] são pessoas em quem eu me espelho, são pessoas que eu sei que eu posso chegar pra conversar, pra desabafar, falar alguma coisa pela qual eu estou passando, então são pessoas que eu realmente confio lá na igreja sabe.

Para Daniel os amigos da igreja que frequenta, Testemunhas de Jeová, são "mais do que irmãos", pois quando seu pai foi detido não se afastaram dele, apoiando-o e dando conselhos sobre como enfrentar a situação. Por causa dessa solidariedade, Daniel ressalta que são pessoas que vão ganhando o seu "prestígio". Além desses amigos Daniel também relata o espaço do trabalho como fonte de amizades e boas relações, contando inclusive que às vezes passa férias com o patrão e os colegas de serviço.

A fala de Daniel coloca luz em um importante aspecto do processo de socialização dos adolescentes que vai além da família e da escola. O grupo de pares seja da igreja, do trabalho, da escola ou de outros espaços, também representam um intenso papel socializador, que atravessou a resposta dos participantes em momentos variados. Além dos amigos terem sido determinantes para a escolha do Instituto, como nos casos de Daniel, Jonas e Daisy, eles também compõem um grupo externo à família com quem os adolescentes convivem e que exercem influência sobre suas vidas e acrescentam elementos importantes em suas experiências, inclusive em relação à escolarização.

Para Cássio, a relação com a religião surgiu quando a pesquisadora perguntou o significado de um grande crucifixo colorido com as cores da Jornada Mundial da Juventude (JMJ) realizada no Brasil em julho de 2013 que ele estava usando no momento da entrevista. Mesmo que a religião não tenha surgido espontaneamente em sua fala, Cássio respondeu a essa pergunta esclarecendo que é católico e atua como acólito em alguns cultos. Em função de sua atuação constante nas atividades da Igreja, o padre da paróquia deu-lhe como presente uma viagem para participar da JMJ no Rio de Janeiro.

É importante deixar registrado que todos os adolescentes, exceto Cássio, frequentam igrejas protestantes, não aquelas classificadas como históricas, mas participam de cultos de denominações pentecostais e neopentecostais. Embora não seja objetivo desta dissertação discutir esta questão, convém assinalar o trabalho de proselitismo realizado por essas denominações confessionais, que buscam reunir os fiéis não apenas em função dos aspectos mais propriamente religiosos, mas visam oferecer a eles um espaço de sociabilidade, que é relevante para manter a união social e espiritual dos crentes.

Todavia, trata-se apenas de uma observação que não pode ser generalizada, já que foi registrada em um grupo reduzido de sujeitos, mas que pode ser útil para se discutir a filiação religiosa de adolescentes estudantes e a eventual articulação entre crenças e escolarização. 


\subsection{A apropriação do conhecimento e a sociabilidade no Instituto}

Outro fator importante na experiência escolar dos sujeitos pode ser analisada a partir da relação que eles mantêm com o saber e a aprendizagem conforme pode ser apreendido em diversas trajetórias.

Ao descrever seu desempenho ao longo do ensino médio Sara ressalta que não estuda para conseguir notas altas, mas porque gosta de estudar e de aprender, rompendo com uma relação utilitarista do estudo, segundo a qual a escolarização vale somente pela nota final do boletim. Além disso, ela também considera a escola importante para a formação do caráter, pois ao propiciar contato com pessoas diferentes a escola permite o desenvolvimento de comunicação, troca de experiências e respeito entre pessoas diferentes.

Desse modo Sara ressalta a importância do contato com a alteridade, isto é, com alunos e professores portadores de capital cultural diverso do seu, como fator relevante para sua formação e que comprova a importância da escola no estabelecimento desses contatos e no desenvolvimento da comunicação. Sara compara sua trajetória com a do pai que estudou em fazenda no interior de Minas Gerais e que por isso, segundo ela, apesar de ser sociável não sabe se expressar de forma adequada em todas as situações.

Esses contatos propiciados pela escola permitem o convívio com pessoas diferentes o que promove a aquisição de maior experiência e que pode ajudar em várias situações sociais. O exposto por Sara vai em direção ao analisado por Romanelli (2013, p.43), que demonstra como a convivência com pessoas diferentes, social e culturalmente permite ao sujeito a ampliação e alteração de sua trajetória, portanto, "a relação com a alteridade é significativa na aquisição de capital cultural".

Além disso, Sara ressalta a importância do Instituto na preparação para o mercado de trabalho, assim como André que considera a formação que recebe da escola boa para quem quer trabalhar como técnico e que gosta "da parte técnica", pois aprende a criar equipamentos e colocá-los em funcionamento. Isso vai ao encontro da importância que ele confere à escola, cuja função seria "formar profissionais, para formar uma pessoa, formar um... cidadão".

Apesar disso André tece críticas severas ao Instituto e à grade curricular do curso que não segue a mesma ordem das demais escolas, nas quais as disciplinas são divididas em “frentes" com professores específicos e também por não ter no último ano do Instituto disciplinas como história, matemática e física, consideradas importantes para a aprovação no vestibular. 
Para Cássio a boa relação com o saber aparece no desenvolvimento de sua capacidade de articular os conhecimentos adquiridos em uma área com os de outra. Ele relata ter conseguido aproveitar os conhecimentos e habilidades desenvolvidas no curso de automação industrial em sua prática no teatro, uma vez que lhe concedeu maior percepção sobre como agir em diferentes situações e melhorar sua capacidade de improvisação para resolução de problemas que surgem em cena. Para Cássio a escola é importante, pois é o espaço da aprendizagem, onde os erros são permitidos de modo que possam ser corrigidos. A escola também ensina a falar e se comportar corretamente, o que pode ser, segundo Cássio, fundamental em uma entrevista de emprego. Além disso, para ele, a escola permite a convivência entre pessoas diferentes, permitindo troca de experiências, e ainda estimulando a qualificação profissional dos alunos.

Watarai e Romanelli (2009, p. 224) demonstram que a sociabilidade promovida na escola entre alunos e deles com professores e funcionários, permite uma relação profícua com a alteridade, fornecendo aos alunos

acesso a determinadas normas de conduta ausentes de seu capital cultural e que são importantes para aprenderem a se relacionar com pessoas de diferentes posições sociais e também a incorporarem conhecimentos [...] sobre o mercado de trabalho.

Desse modo, a escola transmite, além dos conhecimentos técnicos, uma série de outras capacitações.

Alan, Jonas e Vanda citam a convivência entre os alunos e entre eles e os professores e Daisy e Amanda ressaltam a relação entre professor e aluno como a principal contribuição da escola para a educação. Esclarecem que os professores cobram deles postura mais madura e responsável, não mais passando a matéria de forma resumida, mas obrigando-os a buscarem conhecimentos e informações por si mesmos através, por exemplo, de livros indicados pelos professores. Dessa forma, o Instituto também contribui para transmitir condutas e noções de responsabilidade, uma vez que estimula os alunos a pesquisarem e buscarem informações.

Além do mais, o professor tende a ser visto como um espelho para os alunos que os tomariam como exemplos a serem seguidos, como pode ser visto na fala de Daisy:

Pesquisadora: Como você acha que a escola contribui para sua educação?

Daisy: Às vezes só de eu ver, tipo assim, a vida que algum professor meu tem, sabe? Aí eu tenho mais vontade assim, incentivo de estudar, sabe? Às vezes o professor em si já é um incentivo, então eu acho que isso ajuda... 
Outra participante que ressalta a posição do professor é Sara, que cita, assim como Daisy, Amanda e Alan, a formação dos docentes como um fator que atesta a qualidade do Instituto e citam que alguns deles possuem mestrado e doutorado, como já foi descrito. Para Sara e Daisy isso parece ter uma influencia mais específica, já que Sara cita em sua entrevista o desejo de ser professora e, assim como Daisy, fazer mestrado e doutorado no futuro.

A importância dada à aprendizagem também pode ser percebida na fala dos outros sujeitos. Quando perguntados se a escola é importante todos responderam que sim, dividindose em três eixos principais as causas dessa importância. Daisy, André, Jonas, Vanda, Sara e Alan responderam que a escola é importante, por fornecer qualificação profissional. Para André, Vanda, Sara e Alan a escola é importante por auxiliar na formação pessoal e do caráter, principalmente através da convivência com pessoas diferentes. E um terceiro eixo que aparece como explicação para a importância da escola é dado por Amanda e Cíntia, para quem a escola ensina a falar e escrever corretamente.

Esses três eixos encontram respaldo no trabalho de Watarai e Romanelli (2009, p. 219) sobre alunos do ensino médio de uma escola pública da rede estadual que citam as disciplinas de matemática e português como as que mais fornecem essa qualificação. Os autores entendem a incorporação desses conteúdos como sendo

[...] relevante para o exercício de suas ocupações e passa a integrar o habitus dos sujeitos e, simultaneamente, amplia seu capital cultural, tornando-os mais preparados para competirem no mercado de trabalho.

A importância do aprendizado da língua portuguesa aparece nas falas de Amanda e Cíntia que mencionam a importância de se aprender a "falar, ler e escrever corretamente". Assim, a escola também apresenta relevância quando pensada em relação à aprendizagem e à participação futura no mercado de trabalho.

Portes (2000) descreve entre as circunstâncias atuantes no trabalho escolar das famílias de camadas populares a existência do outro na vida do estudante e Piotto (2007) ressalta que nos casos tratados por Portes e também por ela, esse outro é, na maioria dos casos, o professor. Também entre os sujeitos da presente pesquisa o professor surge como figura determinante no processo de escolha pelo Instituto Federal.

Os alunos também citam que o Instituto é mais flexível em relação à conduta nas aulas, característica que faz com que os sujeitos citem em momentos diferentes da pesquisa uma semelhança entre o Instituto e o ensino superior, conforme pode ser explicitado pelas falas de Cássio e Sara: 
Pesquisadora: Como foi sua adaptação à escola de ensino técnico?

Sara: Eu estranhei no começo porque eu tive que pegar o ritmo dos professores, uma porque eu estava saindo do ensino fundamental pro ensino médio e outra porque os professores lá, já não é um ensino médio de escola normal, é um ensino médio que eles dão aula pro ensino superior né? Então, eu tive que toma um pouco o ritmo deles né? Não é tudo tão mastigadinho igual era antes, não é só você prestar atenção na aula que você vai bem, então eu tive que me adaptar, mas eu não sofri, eu não tive muitas dificuldades.

Pesquisadora: E o que seus pais pensam sobre sua escolha pelo curso técnico?

Cássio: Eles ficaram muito felizes por mim mesmo porque é uma oportunidade de crescimento na vida, tanto profissional, quanto pessoal, porque a gente nota que a gente amadurece bastante, a gente adquire muita responsabilidade, a gente trabalha no estilo faculdade mesmo, a gente faz a nossa própria escolha, o professor não traz mais na sala prontinho e fala "o, tá aqui, vocês usam", não, "pra tal dia, eu quero que vocês comprem tal coisa pra trazer pra aula, quem não trouxer vai ficar sem fazer", então a gente aprende essa coisa de ter que correr atrás das coisas, então ajuda a gente bastante na vida.

Do conjunto das falas dos alunos pode-se depreender que os alunos avaliam a escolarização no Instituto como positiva e de boa qualidade na transmissão de conhecimentos tanto específicos, referidos à capacitação profissional, quanto para sua formação geral. Por outro lado, os sujeitos também percebem a importância da rede de sociabilidade criada no espaço social da escola, tanto entre pares quanto entre alunos e professores, como elemento que contribui para a incorporação de novas experiências e que também ampliam seu capital cultural enriquecem suas trajetórias pessoal e escolar. 


\section{CAPÍTULO 6: TRABALHO E EXPECTATIVAS FUTURAS}

Tal como já foi exposto, no momento da entrevista todos já haviam trabalhado ou estavam trabalhando, seja devido ao estágio obrigatório do curso de automação industrial ou ainda em outras áreas que não tinham relação com o estágio. Por isso, apresenta-se inicialmente a participação dos alunos no mercado de trabalho, que ocorre paralelamente à frequência nas aulas do Instituto, para em seguida analisar-se suas expectativas de trabalho após a conclusão do curso e seus projetos para continuidade da escolarização no ensino superior.

\subsection{A relação dos alunos com o trabalho}

Todos os participantes mantêm uma relação próxima com o ambiente do trabalho, sendo que em algumas trajetórias essa aproximação surge de forma mais enfática nos casos de Vanda, Daniel, Cíntia, Amanda, Sara e Jonas. Por outro lado, Cássio, Alan, Daisy e André já tinham experimentado a experiência do trabalho devido ao estágio obrigatório.

Assim, entre os entrevistados, as vivências da adolescência vão além do processo educacional e do lazer e inclui os vínculos com o trabalho que é exercido concomitantemente com o curso técnico. Desse modo, o trabalho é extremamente presente nas trajetórias dos alunos e as experiências adquiridas repercutem no modo como avaliam a escolarização, além de dar a eles relativa independência em relação aos pais. Portanto, o trabalho aparece com mais força quando analisado em conjunto com as expectativas que os adolescentes possuem em relação ao seu futuro, pois acreditam que a escola de ensino técnico contribuirá para conseguirem um futuro profissional melhor do que a situação de seus pais.

As relações mantidas com o mundo do trabalho acabam refletindo processo de socialização e nas aspirações futuras desses adolescentes, pois a convivência com colegas e patrões oferece novas experiências para eles. Apesar de apontado constantemente pelo senso comum, como uma das maiores causas de evasão escolar, a experiência do trabalho em algumas das trajetórias estudadas, permite que esses adolescentes tenham permanecido na escola durante os quatro anos de ensino médio técnico na mesma medida em que avaliam que uma atividade remunerada auxiliará no custeio do ensino superior.

Para Sara, André, Daniel e Jonas seus pais veem o trabalho como importante para garantir o sustento da família. André conta que passou a ter vontade de trabalhar somente aos 17 anos como forma de ter seu próprio dinheiro, sem depender da mesada de seus pais e o 
trabalho aparece com bastante força em suas aspirações futuras. Ele descreve um bom futuro como sendo aquele em que se tem "um bom emprego, um bom salário" e no qual se conquista independência financeira e bons relacionamentos no próprio ambiente de trabalho.

Quanto ao desemprego, André diz que é mais grave se for de um chefe de família, pois toma proporções piores já que todo um conjunto de pessoas depende daquela renda para sobreviver. A experiência de seu pai com o desemprego, situação que perdurou por três meses, foi amenizada por seu pai ser proprietário de imóveis de aluguel, o que garantiu o sustento do grupo familiar.

Alan diz que seus pais trabalham desde muito novos e que eles veem o trabalho como fonte de sustento da família e principalmente como um dever dos indivíduos. Para Daisy seu pai dá tanta importância ao trabalho que poderia passar dias e noites trabalhando que nem perceberia e que às vezes ela e suas irmãs têm a impressão de que ele dá mais importância ao trabalho do que à família, valorizando, portanto, sobremaneira o ato de trabalhar.

Na fala de Daisy é possível notar a existência de um ethos do trabalho, porque mesmo que o dinheiro, segundo ela, surja como a motivação principal para seu pai trabalhar, já que precisa sustentar a família, ela relata que:

[...] Meu pai acha que o trabalho é o principal, porque às vezes ele dá mais atenção para o trabalho do que para a gente, passa mais tempo lá do que com a gente, meu pai valoriza bastante o trabalho [...].

Já sua mãe, apesar de ter parado de trabalhar, também a incentiva, dizendo que não é bom depender do marido ou do pai e que ela deve buscar independência financeira. Esse incentivo por parte da mãe vai ao encontro do que Carvalho (2013) expõe sobre a influencia que as mulheres da família, mãe, avós, tias, exercem sobre as meninas mais novas, incentivando projetos de escolarização mais longos de modo a garantir-lhes condições de vida futuras melhores que a das mulheres mais velhas da família.

A restrição que o pai de Daisy estabeleceu em relação ao trabalho da esposa, mas estimulando as filhas a trabalhar remete à análise feita por Romanelli (1997). A permanência da esposa no ambiente doméstico exerce uma dupla função, quais sejam: de demonstrar a capacidade do marido em suprir as necessidades do grupo familiar, atestando sua posição de chefe de família e também para garantir que os serviços domésticos, essenciais para o bom funcionamento da relação familiar, possam ser exercidos pela esposa, liberando os demais membros desta função. Desse modo, conforme colocado por Romanelli (1997, p. 29), 
(...) as restrições ao trabalho da esposa - mas não ao das filhas - não é tão somente imposição do marido, fundada em valores de uma ideologia sexista, mas corresponde a uma avaliação bastante objetiva do valor pago à força de trabalho feminina.

Para Daisy a vontade de trabalhar surgiu após o ingresso no Instituto, quando ela passou a ter contato com colegas que trabalhavam e por isso tem sua própria renda, não dependendo do dinheiro dos pais. Mesmo assim, Daisy prefere deixar sua relação com o mundo do trabalho restrita ao estágio obrigatório para conclusão do curso, uma vez que pretende se dedicar com maior exclusividade aos estudos até o término do ensino médio. Para ela o trabalho é essencial, principalmente pela renda que ele oferece, mas também por possibilitar a aquisição de experiência prática, além de propiciar a convivência com outras pessoas.

Em relação ao desemprego Daisy diferencia a vivência dessa situação por alguém jovem e solteira como ela, que apenas passaria a depender dos pais novamente, e um chefe de família que é o principal provedor de uma família e deixaria de ter condições de pagar as contas e despesas da casa.

Já Cássio relata que seus pais não gostariam que ele começasse a trabalhar cedo para que isso não atrapalhasse seus estudos, mas que eles veem o trabalho como uma possibilidade de crescimento e acabaram apoiando a entrada do filho no mercado de trabalho. Na mesma esteira dos pais de Cássio, na família de Vanda o trabalho é visto também como parte do desenvolvimento pessoal e oportunidade para conquista de uma vida com maior estabilidade.

Sarti (2005) chama a atenção para o aspecto moral do trabalho, cuja importância excede a mera necessidade financeira, ainda que essa condição seja fator preponderante e esteja presente na fala dos sujeitos da presente pesquisa. Essa autora demonstra que o trabalho constitui uma ética, que separa o trabalhador, do desocupado, do criminoso, especialmente no caso masculino, não é sem razão, portanto, que entre os entrevistados o universo do trabalho apareça quase sempre ligado à posição econômica e familiar do pai, que surge como o principal provedor da família. Segundo Sarti $(2005$, p. 88), “o trabalho é muito mais do que o instrumento da sobrevivência material, mas constitui o substrato da identidade masculina, forjando um jeito de ser homem".

Cássio sempre desejou trabalhar para ajudar sua família e vê o trabalho não só como necessidade, mas também como oportunidade para aprender a ter responsabilidade. Em oposição ao trabalho, Cássio percebe o desemprego como um problema crescente, como "uma situação bem crítica" e que vem atingindo vários setores da economia, inclusive a área de automação industrial. 
Para Daniel o desejo de trabalhar sempre esteve presente, porque deseja ter independência financeira em relação aos pais e também por "não gostar de ficar vagabundeando [...] é chato ficar dormindo o dia inteiro, tem uma hora que cansa". Para ele o trabalho é um prazer e diz gostar de trabalhar, "colocar a mão na massa". Daniel já teve um período de desemprego durante cerce de dois anos e sua relação positiva com o trabalho vem dessa experiência, que ele relata ter sido "bem ruim... não ter o que fazer é bem ruim [...] porque precisa do dinheiro e não ganha, e aí fica em uma situação complicada”.

Amanda, por sua vez, relata sempre ter trabalhado, uma vez que buscava "se virar" e para conseguir seu "dinheirinho". Ela conta que já no sétimo ano do ensino fundamental ajudava uma professora a vender cosméticos através de catálogos, ganhando uma quantia por sua ajuda. Amanda diz amar trabalhar, "meu sonho na vida é trabalhar, hoje meu sonho é acabar meu estágio de 360 horas e começar a trabalhar o dia inteiro”. Essa sua paixão pelo trabalho é explicado pela primeira experiência que ela teve com o mercado formal de trabalho por volta dos 16 anos em uma empresa de assistência técnica de aparelhos eletrônicos onde ficou por um ano. Essa experiência mostrou-lhe que com "o contato com pessoas diferentes você aprende muito, cresce muito seu lado pessoal".

Assim como Daniel, Amanda considera ter passado por situação de desemprego num período de três meses em que saiu do primeiro emprego e conseguiu o estágio na empresa de automação, fase que ela considera ter se sentido "meio depressiva" já que não gosta de ficar em casa e sim de trabalhar. Para Amanda, assim como para Daisy e André, o emprego lhes garante maior independência financeira e, no caso de Amanda, a possibilidade de ajudar os pais com os gastos familiares, algo que ela ainda não pôde fazer, mas pretende conseguir. Esse estímulo à independência vem de seu pai que, conforme relatado pela adolescente, começou a trabalhar muito jovem e por isso a ensina a não depender de ninguém e que "se quer ser alguma coisa na vida [...] tem que trabalhar".

Para Sara o desejo de trabalhar também é descrito como sendo antigo e diz que apesar de procurar não havia conseguido emprego antes pela limitação de horário, uma vez que estudava à tarde e as vagas de emprego exigiam jornada completa de oito horas. Ao longo da entrevista, inclusive, ela conta ser muito assediada por usinas, escolas e empresas em geral para vagas de trabalho por ter um currículo muito bom, com vários cursos.

Ela, porém não aceita as propostas em função do horário necessário para frequentar as aulas e se dedicar aos estudos. No momento da entrevista, quando ainda trabalhava no escritório de advocacia, tinha por hábito aproveitar os momentos de menor atividade no escritório para estudar ou fazer trabalhos escolares. O trabalho sempre esteve entre seus 
interesses principalmente como uma fonte de experiências práticas para a faculdade, e também como forma de conseguir certa independência financeira em relação à seus pais.

Como Daniel e Amanda, Sara diz que o trabalho é importante para o sustento, mas também "para ter uma vida". Segundo ela, ficar em casa é "horrível” e o trabalho possibilita “contato com outras pessoas, você conversa [...] eu acho que trabalhar é a gente viver [...]".

Para Cíntia, a vontade de trabalhar surgiu após ela começar sua experiência na cantina escolar de sua mãe e ela diz ter vontade de trabalhar na área de alimentação. Ainda assim a relação que ela mantém com o trabalho é contraditória; ela diz gostar de trabalhar, mas que em alguns dias não gosta e também diz: "quando eu não trabalhava eu era mais feliz, mas agora eu sou mais porque eu recebo, entendeu?".

Em relação ao desemprego Cíntia descreve a situação passada por sua mãe durante um ano em que esteve doente e necessitou de muitas cirurgias, perdendo o emprego e dependendo dos pais, avós de Cíntia, que eventualmente a criticavam por não estar ajudando com as contas mensais.

Vanda, por sua vez, diz que mesmo antes de começar a trabalhar já sentia vontade de fazê-lo por almejar independência financeira, ainda que limitada e que, além disso, o trabalho fornece aprendizagem sobre responsabilidade e também a correr atrás daquilo que deseja. $\mathrm{O}$ desemprego para Vanda, assim como para Daisy, apresenta vivências diferentes dependendo da situação em que a pessoa se encontra. No período de seis meses em que Vanda esteve desempregada seus pais a ajudaram o que é uma situação diferente daquela vivenciada por um chefe de família.

Como a maioria de seus colegas Jonas também buscava independência financeira quando, já aos 16 anos ele começou a sentir vontade de conseguir emprego. Foi somente aos 17 anos que ele conquistou seu primeiro e único emprego em uma loja de materiais de construção, no qual estava há sete meses na data da entrevista e que conseguiu através de um sistema da Prefeitura de Sertãozinho que cadastra os jovens interessados em trabalhar com 16 anos ou mais e avisa sobre a disponibilidade de vagas em áreas de seu interesse. Sobre a experiência de trabalhar Jonas relata que gosta devido ao contato que mantém com seus colegas de trabalho, cuja relação é descrita como sendo de muita amizade e descontração.

Por último, Alan também considera a busca pela independência financeira como a força por trás do desejo de trabalhar, ainda que como Daisy ele prefira permanecer estudando até completar o ensino médio. Por isso, até agora tem apenas experiências esporádicas no mundo do trabalho, como ajudante em reparos de eletrodomésticos, como auxiliar do pai e no estágio obrigatório para a conclusão do curso em automação industrial. O trabalho como fonte 
de autonomia financeira é considerado por ele como gratificante uma vez que permite a aquisição de bens sem depender dos pais. Da mesma forma que Daisy e Vanda, Alan relata que o desemprego para um chefe de família ocorre de forma mais problemática e preocupante do que para alguém que não tem tal responsabilidade.

É possível perceber que alguns sujeitos apresentam os mesmos argumentos que seus pais para explicar sua relação com o trabalho e a importância que conferem a ele, como nos casos de Cássio, André, Cíntia, Vanda e Alan. Porém, nas falas de Daniel, Amanda e Sara é possível notar uma superação das orientações parentais em relação ao trabalho.

Enquanto os pais e, sobretudo o pai, são descritos como sujeitos que veem o trabalho como necessidade e fonte de sustento da família, os filhos, apesar de manterem essa avaliação, reelaboram-na após ingressarem no mercado de trabalho. Suas experiências como trabalhadores abriram-lhes novas perspectivas sobre o que é o trabalho que lhes oferece um novo tipo de vivência e contato com pessoas, garantindo-lhes não somente independência financeira, como também uma série de aprendizagens e experiências que não teriam conquistado fora do mercado de trabalho.

\subsection{As perspectivas de trabalho após a conclusão do ensino técnico}

A relação com o trabalho e sua valorização não pode levar ao entendimento de que trabalho e estudo apareçam de forma contraditória para os sujeitos pesquisados; pelo contrário, nos dez casos analisados trabalho e escola estabelecem uma relação paradoxalmente dependente.

Em todos os casos a qualificação recebida no Instituto é vista como a porta de entrada no mercado de trabalho e essencial na conquista de bons empregos. Cíntia relata a importância do curso para o ingresso no mercado de trabalho:

Cíntia: Ah, como aqui é técnico você já vai sair com um emprego praticamente né, você já vai ter uma profissão, então ajuda bastante isso, porque, por exemplo, do ensino médio você vai sair só com o médio então você não vai ter tipo "ah, eu tenho um trabalho já", você vai trabalhar de que? Você pode trabalhar de garçonete num lugar, você pode trabalhar de recepcionista, entendeu? Você não vai trabalhar numa coisa específica, você vai trabalhar num lugar que você ganhe experiência, [...] às vezes [no Instituto] tem alguma aula de como se portar numa entrevista de emprego, como teve num sábado aqui na escola, eles pegaram a manhã inteira pra falar sobre isso, então isso eu acho importante a escola também pro mercado de trabalho. 
Outro dado relevante quanto às possibilidades de trabalho abertas pelo Instituto encontram-se na fala de Daisy para quem a escola ajuda na inserção direta dos estudantes no mercado de trabalho, por divulgar vagas para estágio e emprego nos murais da escola.

Nas famílias dos entrevistados, mesmo quando as mães não exercem atividade remunerada como no caso da mãe de Daisy, as filhas são estimuladas a ingressarem no mercado de trabalho, para que, as mais novas possam ter maior autonomia e independência financeira em suas vidas futuras, ao contrário das progenitoras.

É interessante notar que André e Alan são os únicos que classificam o curso de automação industrial como curso "para homem" e o de química como "para meninas". Apesar de ser uma avaliação estereotipada, associada a uma representação preconceituosa e distorcida das relações de gênero, a concepção de Alan e André lamentavelmente corresponde à realidade.

Quando se consultam dados sobre o número de mulheres matriculadas no último ano do curso de automação industrial constata-se que nove são do sexo feminino no conjunto de 26 alunos. Para o processo seletivo de 2009, havia 15 mulheres entre 107 inscritos.

Por importante que seja essa desigualdade de gênero entre o alunado do Instituto, não há elementos para aprofundar as razões dessa desigualdade porque não se tinha a intenção de discutir essa problemática. No entanto, fica registrado esse dado que poderá contribuir para outros estudos que pretendam analisar a composição da clientela masculina e feminina do Instituto ou mesmo de outras escolas de ensino técnico.

Além de Daniel, Sara, Cíntia, Cássio, Alan e André, Amanda também cita a qualificação profissional como o principal instrumento fornecido pela escola na conquista de um futuro melhor e Alan e André ainda ressaltam essa qualificação técnica como um diferencial do Instituto perante as escolas de ensino médio propedêutico.

\subsection{As expectativas de ingresso no ensino superior}

As expectativas dos adolescentes indicam outras aspirações e a escola de ensino técnico aparece como recurso que não somente os qualifica para obterem melhores empregos com remuneração que eles acreditam que será superior a de seus pais, como abre caminho para continuidade dos estudos com ingresso no curso superior devido à qualidade de ensino e às exigências durante a escolarização.

Daisy, André, Amanda, Vanda, Daniel, Jonas, Cíntia e Alan escolheram o curso de automoção em comparação com o de química, única outra opção disponível e pela qual não se 
interessavam. Eles escolheram o curso sem saber exatamente o que era automação industrial só tomando conhecimento sobre as vantagens de ter escolhido tal curso ao longo dos últimos quatro anos.

Isso nos leva a pensar que a escolha foi feita em razão da escola e não do curso e esse entendimento fica ainda mais claro quando Daisy coloca que sua escolha se deu por ser uma escola federal e que o ensino técnico acabou sendo um "bônus", algo que ela julga que será extremamente importante para sua vida profissional.

A escolha da escola, portanto, demonstra um interesse pelo ingresso no Instituto como possibilidade de realização do ensino médio em instituição de qualidade. O que se pretende enfatizar é que a opção foi, em primeiro lugar, pelo Instituto e secundariamente pelo tipo de curso. Dito de outro modo, o importante para os adolescentes era ingressarem em uma escola que ofereceria ensino que eles classificam como sendo de qualidade e que os capacitaria tanto para alcançarem postos de trabalho bem remunerados quanto os habilitaria para prestar vestibular para o ensino superior.

Daisy e Alan acreditam que a escola fornece os conhecimentos básicos necessários para o exame vestibular e Amanda vai além, citando os conhecimentos adquiridos no Instituto como capazes de auxiliá-la no próprio desenvolvimento escolar durante o ensino superior, principalmente no caso de permanência na área de exatas e tecnologias, como os cursos de engenharia.

As aspirações dos estudantes demonstram que a continuidade da escolarização com ingresso no ensino superior integra suas expectativas em relação ao futuro, embora alguns deles não tenham clareza quanto ao curso que pretendem fazer e se prestarão vestibular após a conclusão do ensino médio.

Alan pretende continuar estudando quando terminar o ensino médio, mas ainda não está certo sobre qual curso fazer. Apesar dessa incerteza, inscreveu-se para prestar vestibular na Fuvest no curso de Engenharia de Produção. Inscreveu-se também no ENEM, pois seu grande sonho é estudar em uma universidade federal, mas especificamente na UFSCar, pois já esteve lá duas vezes com o Instituto, para uma olimpíada de física e depois para visitar o departamento de astronomia. Alan deixa claro que essas visitas ao campus criaram nele um grande desejo de viver o cotidiano da universidade e que por isso a UFSCar é sua primeira opção para o ensino superior.

Caso não passe nos vestibulares, Alan já decidiu fazer cursinho no próximo ano para se preparar melhor para o processo seletivo. Para isso Alan pretende conciliar atividade de 
trabalho com estudo, para poder ser independente financeiramente e mesmo porque seus pais não teriam condições de mantê-lo apenas estudando.

André tem a pretensão de continuar estudando, mas os planos para o ensino superior são condicionados à conquista de um emprego estável como técnico em automação industrial em Sertãozinho. Esse planejamento a longo prazo para os estudos ocorre por ele não ter certeza sobre qual curso escolher, embora se incline por alguma área de engenharia.

Jonas diz pretender realizar curso superior, porém não consegue especificar se fará isso imediatamente ao terminar o ensino médio ou se deixará esse plano para outro momento. Em parte essa indecisão se dá por ele ainda não ter definido qual curso seguir, ficando entre duas áreas muito contrastantes, tendo interesse tanto por direito quanto por alguma especialidade na área de engenharia. Ele pondera dizendo que se tivesse cursado uma escola de ensino médio regular sem dúvidas escolheria o curso de Direito, mas devido a sua experiência na escola técnica, acredita que Engenharia seria uma continuidade ao que já aprende no Instituto.

Além da não ter clareza quanto a quais cursos seguir, Jonas também demonstra certa contradição ao dizer no começo da entrevista que não tinha perspectiva em relação ao ensino superior para no final dizer que não sabe ainda qual carreira seguir.

O projeto de Cássio, como já foi exposto, oscila entre três cursos, letras, psicologia, artes cênicas, todos sem relação direta com o aprendizado obtido no ensino médio. Daniel, por outro lado, na contramão de seus colegas explicita seu desejo de interromper seus estudos após o ensino médio e dedicar-se somente ao trabalho. Para ele a escola é importante porque fornece a capacitação necessária para conseguir uma vaga no mercado de trabalho.

Sara pretende entrar em algum curso de graduação em engenharia, ainda que não tenha se decidido exatamente por qual área, se mecânica, de automação ou elétrica. Após a graduação deseja cursar especialização ou mestrado na área de educação já que apesar de querer cursos na área de engenharia seu objetivo final é tornar-se professora universitária.

Daisy tem intenção de cursar engenharia civil, tendo como primeira opção a USP. Caso não consiga sua segunda opção é a UFSCar, e como última alternativa ela cita o Centro Universitário Moura Lacerda, em Ribeirão Preto, que mantém acordo com a prefeitura da cidade de Daisy e oferece um desconto de $25 \%$ na mensalidade. Ela tem ambição maior de cursar mestrado e doutorado. Amanda, por sua vez, pretende fazer faculdade na área de construção civil, em arquitetura ou engenharia, Cíntia quer cursar gastronomia e Vanda optou por engenharia de automação. 
Quando as expectativas dos adolescentes são analisadas, o trabalho aparece lado a lado com o estudo, já que é com o próprio rendimento que poderão manter-se quando, eventualmente, ingressarem no curso superior, uma vez que seus pais não têm condições financeiras de mantê-los, seja em universidade pública, devido a gastos com moradia, transporte, alimentação, seja em entidade particular, cujo custo é elevado e ao qual são acrescidos gastos com os quais teriam de arcar para manter os filhos estudando.

Essa necessidade de aliar trabalho e estudo surge para Daisy como a principal dificuldade que encontrará para alcançar seus projetos futuros, uma vez que teria que conciliar horários e responsabilidades das duas esferas. Alan, por outro lado, pondera que poderá passar dificuldades financeiras caso não consiga trabalhar ao mesmo tempo em que realiza o curso superior. Apesar disso, acredita que se continuar estudando terá retorno desse investimento no futuro.

Para cinco adolescentes, André, Sara, Amanda, Cíntia e Cássio, seus projetos futuros e os de seus pais e filhos apresentam algumas diferenciações. Para André essa diferenciação é mais aguda, pois enquanto ele pretende ingressar no mercado de trabalho e adiar a realização do curso superior, sua mãe espera que ele inicie o curso superior em alguma universidade, preferencialmente pública, uma vez que sua mãe valoriza mais esse tipo de universidade. Cássio revela conflito entre suas aspirações de estudar em outra cidade, como já foi exposto, e a vontade dos pais de que ele permaneça na localidade onde residem.

As diferenças de expectativas entre os outros participantes e seus pais são mais sutis, mas não menos presentes. Tanto Cíntia quanto os pais almejam a continuidade dos estudos, a questão que se coloca é que o pai prefere que ela curse engenharia, a mãe deseja que ela se dedique a um curso superior voltado para moda e ela própria quer fazer curso de gastronomia.

As expectativas de Sara entram em confronto com as da mãe. Apesar de desejar que a filha chegue à universidade, a mãe não tem expectativas de que ela de fato concluirá o curso superior. Sara já tem essa expectativa, dizendo inclusive que "talvez eu não chegue, mas eu vou morrer tentando". Esse afastamento entre aquilo que a mãe almeja para a filha e as expectativas de Sara é explicado por ela em função do esforço que a mãe sempre empreendeu para garantir sua escolarização, como ela afirma:

Eu acho que como minha mãe fez o possível e o impossível, eu acho que o limite dela é um pouco perto demais, sabe? Eu acho que ela não vê tão distante quanto eu vejo.

As entrevistas, portanto, permitem notar aspirações variadas tanto dos alunos quanto de seus familiares, uma vez que o ensino técnico oferece a possibilidade de inserção no 
mercado de trabalho "com o objetivo de ter uma formação técnica reconhecida e gratuita e também para adquirir um bom preparo para a universidade" (LOPONTE, 2011, p. 2).

O exame dos dados indica que a escolha por uma dessas alternativas não é feita no início do curso, mas é deslocada para sua conclusão. Como o maior rendimento familiar é de aproximadamente seis salários mínimos os pais não teriam condições para custear o ensino superior.

André: Pretender, [fazer curso superior] eu pretendo, agora se acontecer de eu conseguir estabilizar num emprego, ganhar um certo salário que dê pra mim ser independente, vamos dizer assim, capaz que eu vou pensar em mais pra frente, não que eu vou parar, mas mais pra frente, agora não.

A escolha pelo ensino superior e pela modalidade de carreira são deixadas, portanto, para a etapa final do ensino médio técnico e pode ocorrer que esses alunos optem por cursos sem relação direta com automação industrial como ocorre com Jonas, Cássio e Cíntia cujas opções são do universo das ciências humanas e não das ciências exatas como se poderia esperar de um estudante de curso técnico em automação industrial.

\subsection{Os alunos após a conclusão do ensino técnico}

A realização do curso técnico não interfere de forma determinante na escolha do curso superior. Entre aqueles que almejam o ingresso no ensino superior há sete participantes que citam algum tipo de engenharia, um que cita profissões na área de moda ou alimentos e dois que citam cursos na área de humanidades. No quadro abaixo é possível ver a expectativa de cada sujeito em relação ao ensino superior e o que efetivamente os adolescentes estão fazendo após a conclusão do ensino médio. 


\begin{tabular}{|c|c|c|}
\hline Sujeito & $\begin{array}{l}\text { Expectativa em relação ao } \\
\text { curso superior }\end{array}$ & $\begin{array}{c}\text { Atividades realizadas após conclusão do } \\
\text { ensino médio }\end{array}$ \\
\hline Alan & Engenharia & Cursando Estatística/ Faculdade pública \\
\hline Amanda & Engenharia ou Arquitetura & $\begin{array}{l}\text { Cursando Arquitetura e Urbanismo/Faculdade } \\
\text { particular }\end{array}$ \\
\hline André & Engenharia & Trabalhando e fazendo cursinho pré-vestibular \\
\hline Cássio & $\begin{array}{l}\text { Letras, Psicologia ou Artes } \\
\text { cênicas }\end{array}$ & $\begin{array}{c}\text { Trabalhando e finalizando curso técnico em } \\
\text { outra instituição }\end{array}$ \\
\hline Cíntia & Moda ou gastronomia & Cursando Gastronomia/ Faculdade particular \\
\hline Daisy & Engenharia civil & $\begin{array}{l}\text { Cursando Engenharia Civil/Faculdade } \\
\text { particular }\end{array}$ \\
\hline Daniel & $\begin{array}{l}\text { Não pretende cursar ensino } \\
\text { superior }\end{array}$ & Trabalhando e estudando para concurso público \\
\hline Jonas & Direito ou Engenharia & Fazendo cursinho pré-vestibular \\
\hline Sara & Engenharia & $\begin{array}{l}\text { Cursando Engenharia elétrica/ Faculdade } \\
\text { particular }\end{array}$ \\
\hline Vanda & Engenharia de automação & Trabalhando \\
\hline
\end{tabular}

QUADRO 4 - Expectativas em relação ao ensino superior e atividade dos alunos após a conclusão do ensino médio

Os dados do quadro acima mostram que cinco alunos, Alan, Amanda, Cíntia, Daisy e Sara já ingressaram no curso superior, quatro deles em estabelecimentos privados, e Alan conseguiu aprovação na UFSCar, universidade pública. Dos demais Jonas, está fazendo cursinho pré-vestibular e André trabalha e faz cursinho semelhante. Entre os outros dois que trabalham, Cássio exerce atividade remunerada em uma livraria também está concluindo curso técnico em outra instituição enquanto Daniel estuda para prestar concurso público. Por último, encontra-se Vanda, que apenas trabalha, mas ainda tem planos de cursar faculdade.

Dentre os alunos que estão estudando Sara, Amanda, Daisy e Cíntia relataram estar também trabalhando. Sara cursa faculdade no período noturno e trabalha no setor administrativo de grupo de planos de saúde. Amanda faz estágio em loja de materiais elétricos no período da manhã e Daisy trabalha em uma loja de equipamentos eletrônicos em sua cidade natal durante o dia e cursa faculdade no período noturno em Ribeirão Preto. Além do curso de gastronomia Cíntia já está trabalhando na área em uma padaria. Alan conseguiu auxílios alimentação e moradia na UFSCar e conta com ajuda dos pais sem precisar trabalhar, porém espera conseguir uma atividade remunerada na própria universidade, como bolsa atividade.

Como nove alunos afirmaram que desejavam ingressar no ensino superior, exceto Daniel, os dados mostram que metade deles concretizou essa aspiração e conseguiram inclusive aprovação nas carreiras que haviam escolhido, exceto Alan que conseguiu 
aprovação em outro curso. Há ainda dois outros, André e Jonas, que estão fazendo cursinho o que indica a tentativa de realizar suas aspirações de escolarização.

Porém Cássio parece não ter conseguido atingir seus objetivos, já que suas opções pela continuidade de escolarização incluíam três cursos na área de humanas, mas ele trabalha e finaliza curso técnico em outra instituição. O mesmo pode ser aplicado a Vanda cuja aspiração era por engenharia de automoção, mas que está apenas trabalhando.

Mesmo nos casos de André e Jonas, que fazem curso pré-vestibular, ou nos de Cássio e Vanda, não se pode supor que suas aspirações não venham a ser realizadas ao longo do tempo ou que eles alterem seus projetos.

Nesse sentido, a retomada da coleta de dados após a conclusão do trabalho de campo trouxe algumas informações que ampliaram os referenciais empíricos, o que suscita a necessidade de pesquisas longitudinais. Sobretudo os casos dos quatro alunos citados acima poderiam ser retomados para se conhecer o modo como se posicionaram frente a aspirações que ainda não haviam conseguido concretizar.

O exame dos dados mostra ainda que apenas Alan conseguiu ingressar em curso superior de escola pública o que contraria os projetos de aprovação em instituições públicas dos demais sujeitos, o que leva a se questionar por que não conseguiram acesso a universidades públicas.

A comparação entre expectativas e a realidade, escolar e profissional, vivida pelos sujeitos leva a algumas interpretações. $\mathrm{Na}$ metade dos casos, ou seja, cinco alunos concretizaram suas expectativas. E se acrescentarmos os dois que fazem cursinho prévestibular esse número aumenta.

Cinco alunos que ingressaram no ensino superior e Cássio, Jonas, Daniel e Vanda não se encaminharam para exercer o tipo de atividade profissional para a qual foram habilitados apenas André trabalha em atividade ligada ao curso mas faz curo pré-vestibular e pretende ter acesso ao ensino superior. Portanto nove alunos não seguiram a carreira para a qual foram habilitados no instituto. Isso suscita outra indagação: será que isto ocorre com alunos de outros cursos do Instituto, seja no campus de Sertãozinho, seja em outros campi?

Nesse caso, os cursos do Instituto não estariam preparando trabalhadores qualificados para o mercado de trabalho mas atuariam como cursos preparatórios para o acesso ao ensino superior de filhos de famílias das camadas populares, como pode ser constatado abaixo. No entanto, trata-se apenas de uma interrogação que surgiu no final da pesquisa e que fica em aberto, já que depende de outras investigações para poder ser respondida. 
Por outro lado, é constante nas falas dos participantes a percepção de que o Instituto era a única opção disponível para a realização de uma escola pública e de qualidade, o que nos leva a indagar o que assegura essa qualidade? Será o corpo docente formado por

professores com titulação de mestrado e doutorado e, portanto, com mais conhecimento e experiência docente? Será o processo de seleção pelo qual esses jovens passam antes de ingressarem?

Segundo dados do website do Instituto Federal São Paulo, em 2013 o curso de automação industrial contou com 184 alunos inscritos no processo seletivo, totalizando uma relação de candidato/vaga de 4,6. Em 2009, primeiro ano em que há dados, essa relação era de 2,68, e inscreveram-se 92 candidatos do sexo masculino e apenas 15 do sexo feminino na seleção para o curso de automação industrial. Mais dados acerca de número de inscritos constam do APÊNDICE B.

A grande disparidade entre candidatos do sexo masculino e feminino fica aqui registrada como dado relevante para se indagar sobre as razões de tal disparidade, que realimenta a representação de que há cursos para homens e para mulheres e articula-se às análises sobre escolarização e relações de gênero. Todavia, por mais instigante que seja tal diferenciação não há como aprofundá-la, já que não cabe nos limites deste trabalho. No entanto, esse registro é importante para alimentar futuras pesquisas sobre a clientela desse curso, sobre sua divulgação e quais as razões que afastam as mulheres do processo seletivo.

Por outro lado, o processo seletivo aprova alunos com melhor desempenho escolar no ensino fundamental e, simultaneamente, exclui grande quantidade de adolescentes que poderiam se beneficiar desse ensino de qualidade. No entanto, quando se examinam os dados do ANEXO A que mostra a renda familiar dos alunos, o que se constata é que o Instituto recebe adolescentes de famílias de baixa renda, de escolaridade reduzida e igualmente com pouco capital cultural. Em 2012, 34,83\% dos alunos matriculados no Instituto possuíam renda familiar per capita entre 0,5 e 1 salário mínimo, 28,37\% entre 1 e 1,5 salários mínimos. Já a porcentagem de alunos com renda familiar per capita acima de 3 salários é a menor, representando apenas 2,25\% do corpo discente, conforme consta do ANEXO A.

Pode-se supor que embora os alunos aprovados tivessem bom desempenho escolar no ensino fundamental, a maioria deles não provêm de famílias de camadas médias com renda e escolaridade elevadas e portadoras de capital cultural igualmente elevado. Desse modo, os dados coletados junto ao Instituto indicam que o processo de ingresso não opera uma seleção classista, melhor dizendo, não favorece alunos de segmentos econômica e culturalmente 
privilegiados, mas aprova aqueles com melhor desempenho no ensino fundamental originários de escolas públicas e de famílias com recursos financeiros escassos. Isto é, a seleção ocorre, pelo menos aparentemente, entre uma clientela igualada pelas condições econômicas e culturais. Embora os dados não possam ser generalizados, já que se referem apenas a um curso e a uma unidade específica do Instituto, resta uma questão. Por que, dentre esses alunos não há filhos de famílias de camadas médias?

A presente pesquisa não pretendeu, e nem foi formulada, para responder todas as perguntas acima expostas; o que se propõe é compreender as motivações e as expectativas de pais e filhos ao escolherem esse estabelecimento de ensino e a forma como os filhos se apropriam do que lhes foi transmitido pelos pais. Do mesmo modo este trabalhou possibilitou levantar questões para outras pesquisas sobre o ensino técnico público. 


\section{CONSIDERAÇÕES FINAIS}

Se a família não é o único agente que atua no processo de escolarização e na escolha do ensino técnico, os pais das famílias pesquisadas empenharam-se para que seus filhos tivessem acesso à escolaridade mais elevada do que aquela alcançada por eles. Nesse sentido, pesquisas sobre escolarização de famílias de camadas populares, ou de baixa renda, (LAHIRE, 1997; PORTES, 2000; VIANA, 2005; ZAGO; 2006) têm mostrado o empenho dos pais para seus filhos concluírem o ensino médio e, na medida do possível, ingressarem no curso superior. Lahire (1997) mostra inclusive, que mesmo nos casos em que os pais têm pouco ou nenhum capital escolar, existe uma preocupação deles em relação à escolarização dos filhos.

Nas entrevistas realizadas essa preocupação dos pais com baixa escolaridade com a formação dos filhos fica clara nos casos de Daisy, Vanda e Cíntia. Nos casos das três estudantes os pais tem escolaridade relativamente baixa, com ensino fundamental completo ou incompleto. Mas cada um a seu modo, incentivaram e incutiram nas filhas o interesse pelos estudos seja no acesso ao ensino superior como acontece com Vanda e Daisy, seja pela continuidade dos estudos em cursos técnicos como é o caso de Cíntia.

Nogueira e Nogueira (2009, p. 61-62) ao discutirem a concepção bourdieusiana de classes populares ressaltam que para o autor francês:

\footnotetext{
As aspirações escolares desse grupo seriam moderadas. Esperar-se-ia dos filhos que estudassem apenas o suficiente para se manter (o que normalmente, dados os avanços nas taxas de escolarização, já significa, de qualquer forma, alcançar escolarização superior à dos pais) ou se elevar ligeiramente em relação ao nível socioeconômico alcançado pelos pais.
}

Os autores também ressaltam que os pais investiriam em trajetórias prolongadas somente quando desde muito cedo os filhos exprimissem características de sucesso escolar capazes de justificar tal ação. Bourdieu ainda chama as estratégias de acompanhamento dessas classes de "liberais", por não seguirem a mesma lógica intensa e constante presente nas famílias de classes sociais mais altas. Essa última colocação, porém, deve ser relativizada, uma vez que as próprias características de existência das camadas populares exigem participações diferenciadas dos pais.

Os pais, portanto, realizam escolhas constantes sobre o futuro dos mais jovens, optando por estratégias diferentes para cada filho de acordo com seu rendimento ou interesse pela escola e pelo trabalho. Na mesma medida, os filhos não são submissos aos mandos e 
desmandos dos pais, buscando alternativas de resistência e de escolhas perante as opções colocadas por eles. É por isso que apesar de socializados em uma mesma família os estudantes entrevistados possuem trajetórias escolares muito diferentes das de seus irmãos, que em nenhum dos casos realizam ensino técnico integrado no Instituto. E mesmo quando obrigados a escolherem a escola, no caso de André, ou o curso, como no caso de Cássio, os adolescentes acabam creditando a permanência na escola e no curso à sua própria vontade e não à imposição paterna.

Da mesma forma quando os pais de Cássio e Alan buscam impedir ou coibir a entrada dos filhos no mercado de trabalho, também demonstram a importância que os pais dão à escolarização como possibilidade de melhoria na qualidade de vida dos filhos a longo prazo. Alan, inclusive, diz esperar ter, no futuro, o retorno de sua escolha pelos estudos e não pelo ingresso imediato no mercado de trabalho.

Sendo assim, a família, primordialmente os pais, tem grande importância nas escolhas e expectativas futuras dos filhos na medida em que são os primeiros responsáveis pela socialização da prole e lhes passam de forma consciente ou não a importância do trabalho e da dedicação aos estudos enquanto possibilidades de alcançarem condições de vida melhores que a de seus pais.

Além da família, entretanto, os pares, a escola e seus membros e a religião despontam como fatores e atores de extrema importância na socialização e escolhas dos sujeitos entrevistados, agindo de forma direta e indireta nas escolhas de pais e filhos quanto ao futuro escolar. Essas ações se concretizam, por exemplo, na participação dos professores de ensino fundamental dos sujeitos pesquisados em estimulá-los a ingressarem no Instituto, ou ainda quando esses adolescentes se sobressaíam nos afazeres escolares, demonstrando aos pais a capacidade dos filhos e com ela a possibilidade de maior investimento em cada um deles. Os amigos e a religião, por sua vez, aparecem como elementos de apoio e exemplo para a escolarização dos entrevistados.

Conforme Piotto (2007) o processo de apropriação de capitais, escolares e culturais, bem como as estratégias das famílias são heterogêneos, e esses processos não são impositivamente determinados, de forma que os sujeitos também tem participação ativa nos processos de apropriação de capital, de modo que "para que a transmissão do capital cultural ocorra, são necessárias interações efetivas e afetivas” (PIOTTO, 2007, p.7; grifos meus).

Desse modo os êxitos escolares dependem da interação de uma série de fatores, tais quais a mobilização familiar, que pode se dar de formas diferentes de acordo com a camada social a que pertencem, existência de um grupo de apoio no ambiente escolar, a presença do 
outro na trajetória do estudante e autodeterminação dos sujeitos. Esses fatores compõem essas trajetórias, que segundo a autora são, portanto, uma "realização pessoal e social" (PIOTTO, 2007, p.314).

Ainda que o presente trabalho não tenha aprofundado algumas temáticas e elementos oriundos da pesquisa de campo, e que já foram expostos, espera-se que ele permita o surgimento de novas indagações e possibilidades de olhares e análises sobre as relações que se estabelecem entre pais e filhos, que porventura, não são apenas filhos, mas alunos, amigos e cidadãos, e desse modo não estão inseridos somente no grupo familiar, tendo também suas trajetórias atravessadas por outros grupos sociais, que por vezes, os auxiliam na incorporação definitiva da socialização familiar ou, por outras, os ajudam a reformulá-las. 


\section{REFERÊNCIAS}

BARRETO, M. A.; AIELLO-VAISBERG, T. Escolha profissional e dramática do viver adolescente. Psicologia e Sociologia, v. 19, n. 1, p. 107-114, 2007.

BRASIL. Decreto n5.154, de 23 de julho de 2004. Disponível em: <http://www.cefetsp.br/edu/eso/lutasindical/decreto5154.html>. Acesso em: 12 nov. 2011.

BRASIL. Lei $\mathrm{n}^{\circ} 11.892$, de 29 de dezembro de 2008. Disponível em: <http://www.planalto.gov.br/ccivil_03/_ato2007-2010/2008/lei/111892.html>. Acesso em: 22 mai. 2014.

BALARINI, F.B.; ROMANELLI,G. O processo de escolarização de irmãos de acordo com a posição na fratria. Práxis educacional, vol. 8, n¹2, p.61-79, jan-jun 2012.

BERGER, P.; LUCKMANN, T. A construção social da realidade: tratado de sociologia do conhecimento. Petrópolis: Vozes, 1985.

BOURDIEU, P. Questões de sociologia. Rio de Janeiro: MarcoZero, 1983.

Gostos de classe e estilos vida. In: ORTIZ, R. (Org.). Pierre Bourdieu: sociologia. São Paulo: Ática, 1983a, p. 82-121.

. As contradições da herança. In: LINS, D. (Org.). Cultura e Subjetividade: saberes nômades. Campinas: Papirus, 1997.

. Escritos de Educação. Petrópolis: Vozes, 1998.

O poder simbólico. Rio de Janeiro: Bertrand Brasil, 2000.

BREJÓN, M. Recursos humanos, ensino técnico e desenvolvimento: uma perspectiva brasileira. São Paulo: Pioneira, 1968.

CASSIOLA, F. R. As novas diretrizes e bases nacionais para a educação profissionalizante segundo o parecer CNE/CEB n'16/99. 2002. 40 f. Monografia (Especialização em Planejamento e Gestão de Organizações Educacionais) - UNESP, 2002.

CARVALHO, M. P. Teses e dissertações sobre gênero e desempenho escolar no Brasil (19932007 - Qual o lugar das famílias? In: ROMANELLI, G.; NOGUEIRA, M.A.; ZAGO, N.

Família e escola: novas perspectivas de análise. Petrópolis, RJ: Vozes, 2013, p.61-82.

CÊA, G. S. S; SANDRI, S. Formação geral e mundo do trabalho: horizontes em disputa. Currículo sem fronteiras, n.1, p. 76-93, 2008.

CENTRO PAULA SOUZA. Disponível em: <www.centropaulasouza.sp.gov.br/>. Acesso em: 09 maio 2011.

CORTI, A.P.; SOUZA, R. Diálogos com o mundo juvenil: subsídios para educadores. São Paulo: Ação educativa, 2004. 
CUNHA, L. A. C. R. Política educacional no Brasil: a profissionalização no ensino médio. Rio de Janeiro: Eldorado, 1977.

. O ensino industrial-manufatureiro no Brasil. Revista Brasileira de Educação, n.14, p. 89-107, 2000.

Ensino médio e ensino técnico na América Latina: Brasil, Argentina e Chile.

Cadernos de Pesquisa, n. 111, p. 47-70, 2000.

DAMATTA, R. Relativizando: uma introdução à Antropologia Social. Petrópolis: Vozes, 1981.

DURHAM, E.R. Família e reprodução humana. In: DURHAM, E.R. et al. Perspectivas antropológicas da mulher 3. Rio de Janeiro: Zahar, 1983, p.13-44.

FABBRINI, A.; MELUCCI, A. Lètá dell’oro: adolescenti tra sogno. Ed. Esperienza. Milano: Goangiacomo Feltrinelli Editores, 1992

FARTES, V. L. B. Reforma da educação profissional e crise das identidades pedagógicas e institucionais. Cadernos de pesquisa, n. 135, p. 657-684, 2008.

FERRETTI, C. J. Formação profissional e reforma do ensino técnico no Brasil: anos 90. Educação e Sociedade, n. 59, p. 225-269, 1997.

. Mudanças em sistemas estaduais de ensino em face das reformas no Ensino Médio e no Ensino Técnico. Educação e Sociedade, n. 70, p. 80-99, 2000.

. Problemas institucionais e pedagógicos na implantação da reforma curricular da Educação Profissional técnica de nível médio no IFSP. Educação e Sociedade, n. 116, p. 789-806, 2011.

FISCHER, M. C. B.; FRANZOI, N. L. Formação humana e educação profissional - diálogos possíveis. Educação, Sociedade e Culturas, n. 29, p. 35-51, 2009.

FRANCO, M. A. C.; CASTRO, C. M. A contribuição da educação técnica à mobilidade social. Cadernos de Pesquisa, n. 36, p. 41-66, 1981.

FONSECA, C. Quando cada caso NÃO é um caso: pesquisa etnográfica em educação. Revista Brasileira de Educação, Rio de Janeiro, n. 10, p. 58-78, 1999.

GLORIA, D.M.A. Relação entre escolaridade e diferenças constitutivas das fratrias. Paidéia, 2005, p. 31-42.

GUERREIRO, M. D.; ABRANTES, P. Como tornar-se adulto: processos de transição na modernidade avançada. Revista Brasileira de Ciências Sociais, n. 58, p. 157-175, 2005.

INSTITUTO BRASILEIRO DE GEOGRAFIA E ESTATÍSTICA. Cidades, Barrinha. 2010b. Disponível em:

<http://www.ibge.gov.br/cidadesat/xtras/perfil.php?codmun=350560\&search=saopaulo|barrin ha>. Acesso em 04 set. 2013. 
INSTITUTO BRASILEIRO DE GEOGRAFIA E ESTATÍSTICA. Cidades, Sertãozinho. 2010a. Disponível em: <http://www.ibge.gov.br/cidadesat/topwindow.htm?1>. Acesso em: 04 jan. 2012.

INSTITUTO BRASILEIRO DE GEOGRAFIA E ESTATÍSTICA. Produto Interno Bruto dos Municípios. 2010c. Disponível em:

<http://www.ibge.gov.br/home/estatistica/pesquisas/pesquisa_resultados.php?id_pesquisa $=46$ $>$. Acesso em: 29 set. 2013.

INSTITUTO FEDERAL DE EDUCAÇÃO, CIÊNCIA E TECNOLOGIA. Edital nº. 001/2013 - IFSP Campus Sertãozinho. [2013]. 7 f.

INSTITUTO FEDERAL SÃO PAULO. Disponível em: <http://www.ifsp.edu.br/>. Acesso em: 30 mar. 2013.

INSTITUTO FEDERAL SÃO PAULO. Plano de curso técnico em Automação Industrial, 2007. Disponível em:

<http://www.ifsp.edu.br/index.php/arquivos/category/292sertozinho.html?download=3806\%3 Appc-tcnico-integrado-em-automao-industrial-srt>. Acesso em: 22 ago. 2013.

INSTITUTO FEDERAL SÃO PAULO. Relatório de gestão do exercício de 2012. 2012. Disponível em: <http://www.ifsp.edu.br/index.php/arquivos/category/36-relatriodegesto.html?download=6131\%3Arelatorio-de-gestao-2012>. Acesso em: 26 ago. 2013.

LAHIRE, B. Sucesso escolar nos meios populares: as razões do improvável. São Paulo: Ática, 1997.

LEÓN, O.D. Adolescência e juventude: das noções às abordagens. In: FREITAS, M. V. Juventude e adolescência no Brasil: referências conceituais. São Paulo: Ação Educativa, 2005.

LOPONTE, L. N. A trajetória do jovem estudante do ensino técnico, na opinião dos alunos do Instituto Federal de educação, ciência e tecnologia de São Paulo - IFSP. 2011. Disponível em:

<http://www.anpae.org.br/simposio2011/cdrom2011/PDFs/trabalhosCompletos/comunicacoe sRelatos/0298.pdf.>. Acesso em: 30 out. 2011.

MARGULIS E URRESTI, 2008. La juventud es más que una palabra. In: MARGULIS, M. (editor). La juventud es más que uma palabra: ensayos sobre cultura y juventud. Buenos Aires: Biblo, 2008.

MARTUCCELLI, Danilo. Leccioes de Sociologia del induviduo 2. 2007. Disponível em: $<$ http://www.uff.br/observatoriojovem/sites/default/files/documentos/MartuccelliLecciones_de_sociologia_del_individuo2.pdf>. Acesso em: 20 maio 2014.

MELUCCI, A. Juventude, tempo e movimentos sociais. Revista Brasileira de Educação, n 5 e n6, mai-dez 1997. 
MENDES, I. M.; SEIXAS, A. M. Escola, desigualdades sociais e democracia: as classes sociais e a questão educativa em Pierre Bourdieu. Educação, Sociedade e Culturas, n. 19, p. 103-129, 2003.

MINISTÉRIO DA EDUCAÇÃO. Censo registra 51,5 milhões de matriculados em 2010. 2010. Disponível em: <http://portal.mec.gov.br/index.php?option=com_content\& view=article \&id=16179> . Acesso em: 10 dez. 2011.

MINISTÉRIO DA EDUCAÇÃO. Secretaria de educação profissional e tecnológica: legislação básica. 2005. Disponível em: <http://portal.mec.gov.br/index.php?option $=$ com_content\&view=article\&id=12662\&Itemid=861>. Acesso em: 10 out. 2013 .

MINISTÉRIO DA EDUCAÇÃO. Secretaria de educação profissional e tecnológica. 2008. Disponível em: <portal.mec.gov.br/index.php?option=com content\&view=article\&id=12496\&Itemid=800>. Acesso em: 26 maio 2011.

MOURA, H. C. O problema das aspirações profissionais: algumas notas. Análise Social, v. V, n. 19, p. 503-511, 1967.

MOURA, C. B.; SILVEIRA, J. M. Orientação profissional sob o enfoque da análise do comportamento: avaliação de uma experiência. Estudos de Psicologia, Campinas, v. 19, n. 1, p. 5-14, 2002.

MONTANDON, C. As práticas educativas parentais e a experiência das crianças. Educação e Sociedade, Campinas, vol. 26, n.91, p. 485-507, 2005.

MUELLER, R R.; BIANCHETTI, L.; JANTSCH, A. P. Interdisciplinaridade, pesquisa e formação de trabalhadores: as interações entre o mundo do trabalho e o da educação.

Educação, Sociedade e Culturas, n. 27, p. 175-191, 2008.

NEPOMUCENO, R. F.; WITTER, G. P. Influência da família na decisão profissional: opinião de adolescentes. Psicologia Escolar e Educacional, v. 14, n. 1, p. 15-22, 2010.

NOGUEIRA, C. M. M.; NOGUEIRA, M. A. A sociologia da educação de Pierre Bourdieu: limites e contradições. Educação e Sociedade, n.78, p. 15-36, 2002.

NOGUEIRA, M. A. A escolha do estabelecimento de ensino pelas famílias: a ação discreta da riqueza cultural. Revista Brasileira de Educação, n. 7, p. 42-56, 1998.

NOGUEIRA, M. A.; NOGUEIRA, C. M. M. Bourdieu e a educação. Belo Horizonte: Autêntica, 2009.

OLIVEIRA, R. A divisão de tarefas na educação profissional brasileira. Cadernos de Pesquisa, n. 112, p. 185-203, 2001.

. Possibilidades do ensino médio integrado diante do financiamento público da educação. Educação e Pesquisa, n. 1, p. 51-66, 2009. 
OLIVEIRA, M. D.; MELO-SILVA, L. L. Estudantes universitários: a influência das variáveis sócio-econômicas e culturais na carreira. Psicologia Escolar e Educacional, v. 14, n. 1, p. 23-34, 2010.

OSÓRIO, R. G. O sistema classificatório de "cor ou raça" do IBGE. 2003. Disponível em: <http://www.acaoeducativa.org.br/fdh/wp-content/uploads/2012/10/quesito-cor-IBGE.pdf >. Acesso em: 02 maio 2014.

PAIS, J. M. A construção sociológica da juventude. Análise Social, vol. XXV, p. 139-165, 1990.

PAULA, L. A. L. Educação profissional: investigando a interação família/escola e seu papel na produção da qualidade do ensino. Disponível em:

<http://www.senept.cefetmg.br/galerias/Anais_2010/Artigos/GT9/EDUCACAO_PROFISSIO NAL.pdf.>. Acesso em: 23 out. 2013.

PIOTTO, D. C. As exceções e suas regras: estudantes das camadas populares em uma universidade pública. 2007.Tese (Doutorado) - Instituto de Psicologia, Universidade de São Paulo, São Paulo, 2007.

A escola e o sucesso escolar: algumas reflexões à luz de Pierre Bourdieu.

Revista Vertentes, São João Del Rey, n. 33, jan/jun, 2009.

PORTES, E. A. O trabalho escolar das famílias populares. In: NOGUEIRA, M. A.; ROMANELLI, G.; ZAGO, N. (Orgs.). Família e escola: trajetórias de escolarização em camadas médias e populares. 6 ed. Rio de Janeiro: Vozes, 2000. p. 61-80.

REIS, D. B. Continuar ou desistir? Reflexões sobre as condições de permanência de estudantes negros na UFRB. In: SANTOS, G. G.; SAMPAIO, S. M. R. (Orgs). Observatório da vida estudantil: universidade, responsabilidade social e juventude. Salvador: EDUFBA, 2013, p. 179-196.

RESENDE, T. F.; NOGUEIRA, C. M. M.; NOGUEIRA, M. A. Escolha do estabelecimento de ensino e perfis familiares: uma faceta a mais das desigualdades escolares. Educação e Sociedade, v.32, n.117, 2011.

RISK, E. N. Jovens do sexo masculino de famílias de camadas populares: sociabilidade, identidade, subjetividade, masculinidade. Ribeirão Preto: USP, 2012 [Dissertação de mestrado].

ROMANELLI, G. Famílias de classes populares: socialização e identidade masculina. Cadernos de Pesquisa, n. 1 2, p. 25-34, 1997.

. A entrevista antropológica: troca e alteridade. In: ROMANELLI, G.; BISOLIALVES, Z. M. M. Diálogos metodológicos sobre a prática da pesquisa. Ribeirão Preto: Legis Summa, 1998.

. Questões teóricas e metodológicas nas pesquisas sobre família e escola. In:

ZAGO, N; CARVALHO, M. P.; VILELA, R. A. T. (Orgs.). Itinerários de pesquisa: 
perspectivas qualitativas em Sociologia da Educação. Rio de Janeiro: DP\&A, 2003. p. 245264.

. Pais, filhos, alunos: famílias de camadas populares e a relação com a escola. In: PINHO, S. Z. (Org.) Formação de educadores: o papel do educador e sua formação. São Paulo: UNESP, 2009, p. 371-382.

. Levantamento crítico sobre as relações entre família e escola. In: ROMANELLI, G.; NOGUEIRA, M.A.; ZAGO, N. Família e escola: novas perspectivas de análise. Petrópolis, RJ: Vozes, 2013, p. 29-60.

SANTOS, L. M. M. O papel da família e dos pares na escolha profissional. Psicologia em estudo, v. 10, n. 1, p. 57-66, 2005.

SARTI, C. A família como espelho: um estudo sobre a moral dos pobres. São Paulo: Cortez, 2005, p. 87-138.

. Famílias enredadas. In: ACOSTA, A.R. \& VITALE, J.A.F. (Orgs.) Família,

Redes, laços e políticas públicas. São Paulo: Cortez Ed./PUC-SP, 2010, p. 21-36.

SERTÃOZINHO. Disponível em: <www.sertaozinho.com>. Acesso em: 18 out. 2011.

SERVIÇO NACIONAL DE APRENDIZAGEM INDUSTRIAL. Disponível em: <www.sp.senai.br/ribeiraopreto/>. Acesso em: 9 maio 2011.

SILVA, L. P. Formação profissional no Brasil: o papel do Serviço Nacional de Aprendizagem Industrial - SENAI. História, v. 29, n. 1, p. 394-417, 2010.

SINGLY, F. de. O nascimento do "indivíduo individualizado" e seus efeitos na vida conjugal e familiar. In: PEIXOTO, C. E.; SINGLY, F. de; CICCHELLI, V. (Orgs.). Família e individualização. Rio de Janeiro: FGV, 2000.

. Sociologia da família contemporânea. Rio de Janeiro: Editora FGV, 2007.

SOUZA, A.; LAMOUNIER, B. A classe média brasileira: ambições, valores e projetos de sociedade. Rio de Janeiro: Elsevier, 2010.

SPARTA, M. O desenvolvimento da Orientação Profissional no Brasil. Revista Brasileira de Orientação Profissional, p. 01-11, 2005.

SPOSITO, M. P. Uma perspectiva não escolar no estudo sociológico da escola. Revista USP, São Paulo, n.57, p. 210-226, 2003.

Indagações sobre as relações entre juventude e escola no Brasil:

institucionalização tradicional e novos significados. Jovenes: Revista de Estudios sobre Juventud, México, v. 9, n. 22, jan./jun. 2005.

Juventude e Educação: interações entre educação escolar e a educação não formal. Educação e Realidade, v. 33, n. 2, p. 83-98, 2008. 
THERBORN, G. Sexo e poder: a família no mundo 1900-2000. São Paulo: Contexto, 2006.

THORNE, B. Feminism and the family: two decades of thought. In: THORNE, B.; YALOM, M. (Orgs.). Rethinking the family: some feminist questions. Boston: Northeastern Univ. Press, 1992, p. 3-30.

TUPPY, M. I. N. A educação profissional. In: OLIVEIRA, R. P.; ADRIÃO, T. Organização do ensino no Brasil: níveis e modalidade na Constituição Federal e na LDB. São Paulo: Xamã. 2002, p. 109-122.

VIANA, M. J. B. Longevidade escolar em famílias de camadas populares - algumas condições de possibilidade. In: NOGUEIRA, M. A.; ROMANELLI, G.; ZAGO, N. Família e escola: trajetórias de escolarização em camadas médias e populares. Petrópolis: Vozes, 2000, p.45-60.

As práticas socializadoras familiares como locus de constituição de disposições facilitadoras de longevidade escolar em meios populares. Educação \& Sociedade, Campinas, v. 26, n. 90, p. 107-125, 2005.

WATARAI, F. Trabalhadores adolescentes do sexo masculino: família, escola, trabalho, violência. 2006, 158 f. Dissertação (Mestrado em Psicologia) - Faculdade de Filosofia, Ciências e Letras de Ribeirão Preto, Universidade de São Paulo, Ribeirão Preto, 2006.

WATARAI, F.; ROMANELLI, G. Escolarização e trabalho de adolescentes do sexo masculino das camadas populares. In: CUNHA, M. V.; PASIAN, S. R.; ROMANELLI, G. (Org.). Pesquisas em Psicologia: múltiplas abordagens. São Paulo: Vetor, 2009, p. 205-232.

Filhos, pais, padrastos: relações domésticas em famílias recompostas das camadas populares. 2010. Tese (Doutorado em Psicologia) - Faculdade de Filosofia, Ciências e Letras de Ribeirão Preto, Universidade de São Paulo, Ribeirão Preto, 2010.

WERMELINGER, M.; MACHADO, M. H.; AMÂNCIO FILHO, A. Políticas de educação profissional: referências e perspectivas. Ensaio: avaliação e políticas públicas em educação, n. 55, p. 207-222, 2007.

ZAGO, N. Do acesso à permanência no ensino superior: percursos de estudantes universitários de camadas populares. Revista Brasileira de Educação. v. 11, n. 32, p. 226237, 2006. 


\section{APÊNDICES}

\section{APÊNDICE A - Roteiro de Entrevistas}

\section{Primeiro módulo: Perfil}

1. Qual sua idade?

2. Em que cidade e bairro você mora atualmente?

3. Você sempre morou nesse lugar? (Se não, quais foram os outros locais e por que se mudou).

4. Com quem você mora? (Idade, parentesco, escolaridade, trabalha, estuda ou está desempregado).

\section{Segundo módulo: Família}

1. Quem contribui para as despesas da família? (Se alguém tem rendimentos e não contribui o que faz com o dinheiro).

2. Como é a relação que você tem com as pessoas da sua casa? Em que horas se reúnem?

O que fazem nessas horas?

3. Qual é a ocupação de seus pais? Onde trabalham e o que fazem?

4. Qual é a escolaridade dos seus pais?

5. Você conversa com seus pais? Sobre o que? Quem costuma começar a conversa?

6. Como é seu relacionamento com sua mãe? Com o seu pai? Com quem você tem mais proximidade? Por quê?

7. Qual a importância da mãe na criação e desenvolvimento escolar dos filhos? E do pai? Quais as diferenças?

8. Você tem irmãos? Quantos? Qual a idade e o sexo deles?

9. Como é a relação com seus irmãos?

10. Você recebe conselhos de alguém da sua família? Se sim, de quem?

11. Como são esses conselhos? O que você acha deles? Costuma segui-los?

12. Você conversa com alguém sobre suas experiências na escola?

13. Como é a educação que você recebe da sua família? 
14. Qual a importância que seus pais dão á sua escolarização?

15. Seus pais examinam suas tarefas escolares? Com que frequência e qual dos dois faz isso mais vezes, ou fazem na mesma quantidade?

16. Seus pais te incentivam a melhorar seu desempenho escolar de alguma forma? Se sim, de que forma?

17. Se você trabalha poderia informar qual é seu rendimento, conforme as seguintes faixas de valores?

- Até R \$ 690,00 (valor correspondente a um salário mínimo)

- De R \$ 691,00 até R\$1.380,00

- De $\mathrm{R} \$ 1.381,00$ até $\mathrm{R} \$ 2.070,00$

- Acima de $\mathrm{R} \$ 20071,00$

18. Você poderia informar o rendimento de seu pai e de sua mãe, conforme as seguintes faixas de valores?

- Até R \$ 690,00 (valor correspondente a um salário mínimo)

- De R\$ 691,00 até R \$ 1.380,00

- De $\mathrm{R} \$ 1.381,00$ até $\mathrm{R} \$ 2.070,00$

- De R 20071,00 até R \$2.760,00

- De R \$-2.761,00 até $\mathrm{R} \$ 3.450,00$

- Acima de $\mathrm{R} \$ 3.450,00$

19. Se você tem irmãos e algum deles trabalha você poderia informar qual o rendimento de cada um deles conforme as seguintes faixas de valores?

- Até R\$ 690,00 (valor correspondente a um salário mínimo)

- De $\mathrm{R} \$ 691,00$ até $\mathrm{R} \$ 1.380,00$

- De R \$ 1.381,00 até R \$ 2.070,00

- Acima de R\$20071,00

\section{Terceiro módulo: Ensino}

1. Você já estudou em alguma outra escola? Qual? Por que mudou?

2. Você já teve alguma repetência? (Se sim, por que o atraso).

3. Você encontrava alguma dificuldade nos estudos? (Se sim, quais).

4. E hoje, você encontra alguma dificuldade? (Se sim, quais e se forem diferentes das anteriores como ele(a) percebe isso). 
5. Alguém na sua família fez ensino técnico? (Se sim, parentesco, quando e em que escola).

6. Como foi a escolha pelo ensino técnico? (Quem participou e como).

7. Seu pai ou sua mãe orientaram você para escolher esse curso? Quais as informações que seus pais ofereceram a você?

8. O que seus pais pensam sobre sua escolha pelo curso técnico?

9. Por que você resolveu fazer esse curso específico?

10. Em que momento o ensino técnico integrado surgiu como opção para o ensino médio?

11. Você tinha alguma outra opção de escola, tanto normal quanto técnica? (Se sim, quais e por que optou por essa).

12. O que você acha da formação que você recebe da escola?

13. A escola é importante? Por quê?

14. Do que você gosta na escola? E do que não gosta?

15. Quais as disciplinas que você mais gosta? Por quê? E quais as disciplinas que você menos gosta? Por quê?

16. Como foi seu desempenho escolar durante o ensino médio?

17. Como foi sua adaptação á escola de ensino técnico?

18. Alguém acompanha seus estudos te ajudando com os deveres ou conversando sobre o que você aprende na escola? Quem?

19. Seus pais estão satisfeitos com o ensino que você está recebendo?

20. Como você acha que a escola contribui para sua educação?

21. Como você acha que a escola contribui para o trabalho?

22. Você pensa que a escola pode ajudar você a conseguir um futuro melhor? Como? (Se não, por que).

23. Pretende continuar estudando depois de terminar o ensino médio? Por que? (Se sim, que curso pretende fazer).

24. Afora as pessoas da sua família, com quem você tem mais convivência? (Colegas de trabalho, escola ou pessoas em geral).

25. Como são essas pessoas? O que você acha delas? O que fazem juntos? Sobre o que conversam?

26. Você percebe alguma diferença na sua relação com seus amigos e com sua família? (Se sim, quais são?).

27. Com quem você tem mais liberdade? Por quê?

28. Você e seus amigos conversam sobre os estudos? (Se sim, o que conversam). 


\section{Quarto módulo: Trabalho}

1. Você tem ou teve vontade de trabalhar alguma vez? (Se sim, em que e quais os motivos que te deram essa vontade).

2. Você já trabalhou alguma vez? (Se sim, com quantos anos, qual foi o emprego, como o conseguiu, o que o levou a trabalhar e se gosta de trabalhar).

3. O que sua família achou de você trabalhar?

4. Você trabalha atualmente? (Detalhar: atividade que desempenha, hierarquia administrativa, como são os relacionamentos profissionais e o ambiente de trabalho, remuneração, horários).

5. Você já esteve desempregado? Por quanto tempo? Como foi ficar desempregado?

6. O que você acha do desemprego?

7. O que você acha de trabalhar? (Ou do trabalho, caso o sujeito não exerça nenhuma atividade profissional).

8. O que seus pais e as pessoas próximas de você pensam sobre o trabalho?

9. Qual tipo de emprego você gostaria de exercer?

\section{Quinto módulo: Expectativas em relação ao futuro}

1. Como você se imagina no futuro, depois de terminar o ensino médio?

2. Como você acha que o ensino técnico pode te ajudar nisso?

3. O que você considera que seja um bom futuro? (Com relação á família, trabalho, estudo, residência, colegas e amigos).

4. Como seus pais imaginam que vai ser seu futuro depois de terminar o ensino médio?

5. O que você acha que você pode conseguir? O que você tem que fazer para conseguir? Quais as principais dificuldades que você acha que vai encontrar para isso?

6. Você conversa com alguém sobre seus planos? (Com quem e quem começa o assunto).

7. Como vocês conversam? Elas também falam sobre os planos que elas tem pra você?

8. Há mais alguma coisa que você queira acrescentar ao que já disse?

9. Você poderia dizer como se sentiu durante a entrevista e o que achou de participar da pesquisa? 
APÊNDICE B - Relação candidato/vaga entre 2009 e 2013 nos cursos técnicos integrados ao ensino médio de automação industrial e química.

\begin{tabular}{|c|c|c|c|}
\hline \multirow{2}{*}{ Semestre/Ano } & Curso & $\mathbf{N}^{\circ}$ inscritos & Relação candidato/vaga \\
\hline \multirow{2}{*}{1 \%/2009 } & Automação Industrial & 107 & 2,68 \\
\cline { 2 - 4 } & Química & 68 & 1,7 \\
\hline \multirow{2}{*}{$1 \% / 2010$} & Automação Industrial & 138 & 3,45 \\
\cline { 2 - 4 } & Química & 145 & 3,625 \\
\hline \multirow{2}{*}{$1 \% / 2011$} & Automação Industrial & 213 & 5,33 \\
\cline { 2 - 4 } & Química & 207 & 5,18 \\
\hline \multirow{2}{*}{$1 \% / 2012$} & Automação Industrial & 162 & 4,05 \\
\cline { 2 - 4 } & Química & 148 & 3,7 \\
\hline \multirow{2}{*}{$1 \% / 2013$} & Automação Industrial & 184 & 4,6 \\
\cline { 2 - 4 } & Química & 173 & 4,33 \\
\hline
\end{tabular}

Fonte: Dados retirados do website Instituto Federal de São Paulo. 


\section{ANEXOS}

ANEXO A - Número de alunos matriculados de acordo com a renda família per capita

\begin{tabular}{|l|c|c|}
\hline \multirow{2}{*}{\multicolumn{1}{|c|}{ Intervalo de classes }} & \multicolumn{2}{c|}{$\begin{array}{c}\text { Frequência relativa } \\
\text { (\%) }\end{array}$} \\
\cline { 2 - 3 } & 2011 & 2012 \\
\hline Até 0,5 salário-mínimo (SM) & 14,29 & 12,64 \\
\hline de 0,5 SM a 1 SM & 50 & 34,83 \\
\hline de 1 SM a 1,5 SM & 14,28 & 28,37 \\
\hline de 1,5 SM a 2,5 SM & 14,28 & - \\
\hline de 2,5 SM a 3 SM & 0 & 17,3 \\
\hline Acima de 3 SM & 7,14 & 2,25 \\
\hline
\end{tabular}

Fonte: Quadro XLVII - Número de alunos matriculados, classificados de acordo com a renda per capita familiar, no Campus Sertãozinho (INSTITUTO FEDERAL SÃO PAULO, 2012, p. 107). 


\section{ANEXO B - Infraestrutura do Campus de Sertãozinho}

\begin{tabular}{|c|c|c|}
\hline & Tipo de Utilização & Área $\left(\mathbf{m}^{2}\right)$ \\
\hline 3.1 & Área de salas de aula teóricas & 270 \\
\hline 3.2 & Área de laboratórios de Informática & 167 \\
\hline 3.3 & Área de laboratórios específicos & 909 \\
\hline 3.4 & Área de bibliotecas & 138 \\
\hline 3.5 & Área de apoio pedagógico & 141 \\
\hline 3.6 & Área de atividades esportivas & 0 \\
\hline 3.7 & Área de oficinas para manutenção de equipamentos de ensino & 9 \\
\hline 3.8 & Área de atendimento médico/ondontológico & 0 \\
\hline 3.9 & Área de alojamento para outros usuários & 0 \\
\hline 3.10 & Área para serviços de apoio & 49 \\
\hline 3.11 & Área para atividades administrativas & 334 \\
\hline 3.12 & Outras áreas construídas & 1.440 \\
\hline 3.13 & Total & 3.457 \\
\hline
\end{tabular}

Fonte: Quadro XXXVIII - Infraestrutura física do Campus Sertãozinho (INSTITUTO FEDERAL SÃO PAULO, 2012, p. 100). 
ANEXO C - Infraestrutura detalhada do IFSP - Campus Sertãozinho.

\section{BLOCO 01}

\begin{tabular}{|l|}
\hline \multicolumn{1}{|c|}{ AMBIENTES } \\
\hline Laboratório de Produção Mecânica \\
\hline Laboratório de Controle de Qualidade e Metalografia \\
\hline Laboratório de Hidráulica e Pneumática \\
\hline Laboratório de CNC \\
\hline Laboratório de Refrigeração \\
\hline Sala de aula I \\
\hline Depósito de materiais de laboratório \\
\hline Manutenção de equipamentos \\
\hline Almoxarifado \\
\hline Centro Acadêmico \\
\hline
\end{tabular}

BLOCO 02

\begin{tabular}{|l|}
\hline \multicolumn{1}{|c|}{ AMBIENTES } \\
\hline Diretoria \\
\hline Sala de reuniões \\
\hline Coordenadoria de Extensão \\
\hline Núcleo Técnico-Administrativo \\
\hline Gerência Acadêmica e de Apoio ao Ensino \\
\hline Secretaria de Ensino Superior \\
\hline Secretaria de Educação Básica \\
\hline Serviço de Saúde \\
\hline Sala de Monitoramento \\
\hline Cantina \\
\hline Copa/Refeitório \\
\hline Garagem \\
\hline
\end{tabular}

\section{BLOCO 03}

\begin{tabular}{|l|}
\hline \multicolumn{1}{|c|}{ AMBIENTES } \\
\hline Laboratório de Controladores e Hardware \\
\hline Laboratório de Química e Microbiologia \\
\hline Laboratório de Instrumentação \\
\hline Laboratório de Dispositivos \\
\hline Laboratório de Informática I \\
\hline Laboratório de Informática II \\
\hline Laboratório de Informática III \\
\hline Tecnologia da Informação \\
\hline
\end{tabular}




\begin{tabular}{|l|}
\hline Laboratório de Instalações Elétricas \\
\hline Sala de aula II \\
\hline Sala de aula III \\
\hline Sala de aula IV \\
\hline Sala de aula V \\
\hline Sala de aula VI \\
\hline Sala de professores \\
\hline Biblioteca \\
\hline Coordenação \\
\hline Auditório \\
\hline
\end{tabular}

Fonte: Instalações e equipamentos oferecidos aos professores e alunos do curso (INSTITUTO FEDERAL DE EDUCAÇÃO, CIÊNCIA E TECNOLOGIA, 2007, p .67-68). 


\section{ANEXO D - Estrutura curricular do curso de Automação Industrial}

\begin{tabular}{|c|c|c|c|c|c|c|c|c|}
\hline \multicolumn{8}{|c|}{ 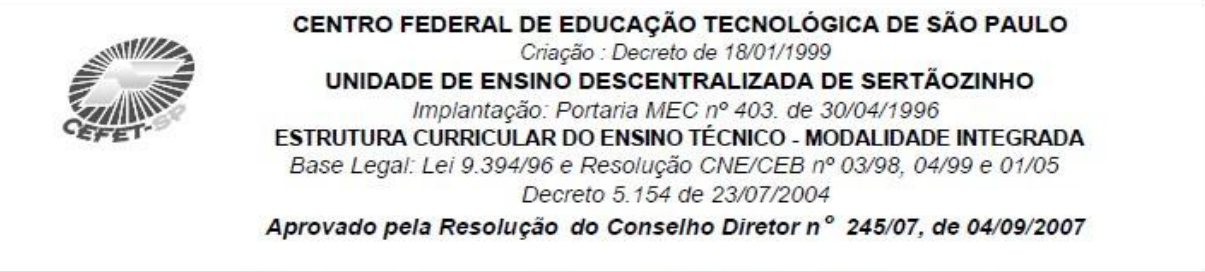 } & $\begin{array}{l}\text { CARGA HORÁRIA } \\
\text { DO CURSO COM } \\
\text { ESTÁGIO }\end{array}$ \\
\hline \multicolumn{8}{|c|}{ Habilitação Profissional - TÉCNICO EM AUTOMAÇÃO INDUSTRIAL } & $\begin{array}{l}\text { PERIODOLEIIVO: } \\
\text { 38 SEMANAS }\end{array}$ \\
\hline COMPONENTES CURRICULARES & $\begin{array}{c}\text { Códigos } \\
\text { Disciplinas }\end{array}$ & $N^{\circ}$ Profs. & \multicolumn{4}{|c|}{\begin{tabular}{l|l|l|l|}
\multicolumn{3}{|c|}{ Aulas/semana } \\
$1^{\circ}$ & $2^{\circ}$ & $3^{\circ}$ & 4 \\
\end{tabular}} & $\begin{array}{l}\text { TOTAL DE } \\
\text { AULAS }\end{array}$ & TOTAL DE HORAS \\
\hline Artes & ART & 1 & 0 & 2 & 0 & 0 & 76 & 57 \\
\hline Automação Eletropneumática e Hidráulica I & APH1 & 2 & 0 & 0 & 3 & 0 & 114 & 86 \\
\hline Automaçäo Eletropneumática e Hidráulica II & APH2 & 2 & 0 & $\mathbf{0}$ & $\mathbf{0}$ & 3 & 114 & 86 \\
\hline Biologia & BIO & 1 & 2 & 2 & $\mathbf{0}$ & 0 & 152 & 114 \\
\hline Controladores Programáveis & CPM & 2 & 0 & 0 & 0 & 4 & 152 & 114 \\
\hline Desenho Técnico & DES & 1 & 2 & $\mathbf{0}$ & $\mathbf{0}$ & 0 & 76 & 57 \\
\hline Educaçäo Fisica & EFI & 1 & 2 & 2 & 2 & 0 & 228 & 171 \\
\hline Eletricidade & ELE & 2 & 4 & 0 & 0 & 0 & 152 & 114 \\
\hline Eletrônica Básica & ELO & 2 & 0 & 0 & 3 & 0 & 114 & 86 \\
\hline Eletrônica Industrial & ELI & 2 & 0 & 0 & 0 & 4 & 152 & 114 \\
\hline Filosofia & FIL & 1 & 1 & 1 & 1 & 1 & 152 & 114 \\
\hline Física & FIS & 1 & 4 & 3 & 0 & 0 & 266 & 200 \\
\hline Geografia & GEO & 1 & 0 & 0 & 1 & 2 & 114 & 86 \\
\hline Gestäo Organizacional de Produçäo e de Pessoas & GPP & 1 & 0 & 0 & 2 & 0 & 76 & 57 \\
\hline História & HIS & 1 & 0 & 2 & 1 & 0 & 114 & 86 \\
\hline Informática Básica & INF & 2 & 2 & 0 & 0 & 0 & 76 & 57 \\
\hline Instalaçöes Elétricas & IEL & 2 & 0 & 3 & 0 & 0 & 114 & 86 \\
\hline Instrumentaçäo Industrial I & INS1 & 1 & 0 & 0 & 2 & 0 & 76 & 57 \\
\hline Instrumentação Industrial II & INS2 & 2 & 0 & 0 & 0 & 4 & 152 & 114 \\
\hline Língua Espanhola & ESP & 1 & 0 & 0 & 0 & 2 & 76 & 57 \\
\hline Lingua Inglesa & ING & 1 & 2 & 2 & 2 & 0 & 228 & 171 \\
\hline Lingua Portuguesa, Literatura Brasileira e Redaçäo & LPL & 1 & 3 & 3 & 3 & 2 & 418 & 314 \\
\hline Máquinas e Equipamentos Elétricos & MEL & 1 & 0 & 0 & 3 & 0 & 114 & 86 \\
\hline Matemática & MAT & 1 & 4 & 3 & 3 & 0 & 380 & 285 \\
\hline Processos Industriais & PRI & 1 & 0 & 0 & 0 & 2 & 76 & 57 \\
\hline Quimica & QUI & 2 & 2 & 2 & 0 & 0 & 152 & 114 \\
\hline Segurança e Medicina do Trabalho & SMT & 1 & 0 & 1 & $\mathbf{0}$ & 0 & 38 & 29 \\
\hline Sistemas Digitais & SID & 2 & 0 & 3 & $\mathbf{0}$ & 0 & 114 & 86 \\
\hline Sistemas Microcontrolados & SMI & 2 & 0 & 0 & 3 & 0 & 114 & 86 \\
\hline Sociologia & soc & 1 & 1 & 1 & 1 & 1 & 152 & 114 \\
\hline Trabalho de Conclusão de Curso & TCC & 2 & 0 & 0 & 0 & 3 & 114 & 86 \\
\hline \multicolumn{3}{|l|}{ TOTAL ACUMULADO DE AULAS } & 29 & 30 & 30 & 28 & & 4446 \\
\hline \multicolumn{3}{|l|}{ TOTAL ACUMULADO DE HORAS } & 827 & 855 & 855 & 798 & & 3335 \\
\hline \multicolumn{8}{|l|}{ ESTÁGIO SUPERVISIONADO } & 360 \\
\hline \multicolumn{9}{|c|}{ CERTIFICAÇÄO FORMAÇÄO INICIAL E CONTINUADA DE TRABALHADORES } \\
\hline \multirow{3}{*}{\multicolumn{9}{|c|}{ Obs: 1) As aulas são de 45 minutos }} \\
\hline & & & & & & & & \\
\hline & & & & & & & & \\
\hline 4) A conclusão de todos os periodos letivos e do estáç & sonado confer & habilitaç & & & & & & \\
\hline
\end{tabular}

Fonte: Dados retirados do website Instituto Federal de São Paulo. 
ANEXO E - Documento de aprovação enviado pelo Comitê de Ética

\author{
Universidade de São Paulo \\ Faculdade de Filosofia, Ciências e Letras de Ribeirão Preto \\ Comitê de Ética em Pesquisa
}

Campus de Ribeirão Preto

Of.CEtPIFFCLRP-USP/012-jsI

Ribeirão Preto, 04 de março de 2013

Prezada Pesquisadora,

Comunicamos a V. Sa. que o projeto de pesquisa intitulado "A IMPORTÂNCIA dA FAMÍLIA NO PROCESSO DE ESCOLHA do ENSINO MÉdIO TÉCNICO" foi reanalisado pelo Comitê de Ética em Pesquisa da FFCLRP-USP, em sua $117^{\text {a }}$ Reunião Ordinária, realizada em 28.02.2013, e enquadrado na categoria: APROVADO (CAAE - 10337912.4.0000.5407).

Solicitamos que eventuais modificações ou emendas ao projeto de pesquisa sejam apresentadas ao CEP, de forma sucinta, identificando a parte do projeto a ser modificada e suas justificativas, e que, ao término do estudo, um relatório final seja entregue, via Plataforma Brasil.

Atenciosamente,

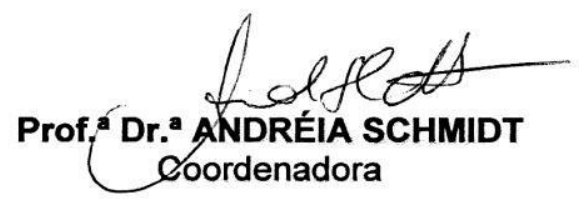

À Senhora

Mariana Simões Flório Ferreira

Programa de Pós-Graduação em Educação da FFCLRP USP

$\mathrm{C} / \mathrm{C}$ :

Prof. Dr. Geraldo Romanelli

Departamento de Psicologia da FFCLRP USP

CEP - Comité de Ética em Pesquisa da FFCLRP

Fone: (16) 3602-4811

Fax: (16) 3633-2660 (direto) ou 3633-5015

Avenida Bandeirantes, 3900 - bloco 3 - sala 16 - 14040-901 - Ribeirăo Preto - SP - Brasil

Homepage: http://umw.ffcliro.usp.br - e-mail: coetp@ffclrp.usp.br 